FINAL REPORT

\title{
PHASE ZERO
}

Goal Study for the Technical and Economic Evaluation of the Compound Parabolic Concentrator (CPC) Concept Applied to Solar, Thermal, and Photovoltaic Collectors

BECHTEL CORPORATION June 1975 


\section{DISCLAIMER}

This report was prepared as an account of work sponsored by an agency of the United States Government. Neither the United States Government nor any agency Thereof, nor any of their employees, makes any warranty, express or implied, or assumes any legal liability or responsibility for the accuracy, completeness, or usefulness of any information, apparatus, product, or process disclosed, or represents that its use would not infringe privately owned rights. Reference herein to any specific commercial product, process, or service by trade name, trademark, manufacturer, or otherwise does not necessarily constitute or imply its endorsement, recommendation, or favoring by the United States Government or any agency thereof. The views and opinions of authors expressed herein do not necessarily state or reflect those of the United States Government or any agency thereof. 


\section{DISCLAIMER}

Portions of this document may be illegible in electronic image products. Images are produced from the best available original document. 
The facilities of Argonne National Laboratory are owned by the United States Government. Under the terms of a contract (W-31-109-Eng-38) between the U. S. Energy Research and Development Administration, Argonne Universities Association and The University of Chicago, the University employs the staff and operates the Laboratory in accordance with policies and programs formulated, approved and reviewed by the Association.

\section{MEMBERS OF ARGONNE UNIVERSITIES ASSOCIATION}

The University of Arizona

Carnegie-Mellon University

Case Western Reserve University

The University of Chicago

University of Cincinnati

Illinois Institute of Technology

University of Illinois

Indiana University

lowa State University

The University of Iowa
Kansas State University The University of Kansas Loyola University Marquette University Michigan State University The University of Michigan University of Minnesota University of Missouri Northwestern University University of Notre Dame
The Ohio State University

Ohio University

The Pennsylvania State University

Purdue University

Saint Louis University

Southern Illinois University

The University of Texas at Austin

Washington University

Wayne State University

The University of Wisconsin

\section{NOTICE}

This report was prepared as an account of work sponsored by the United States Government. Neither the United States nor the United States Energy Research and Development Administration, nor any of their employees, nor any of their contractors, subcontractors, or their employees, makes any warranty, express or implied, or assumes any legal liability or responsibility for the accuracy, completeness or usefulness of any information, apparatus, product or process disclosed, or represents that its use would not infringe privately-owned rights. Mention of commercial products, their manufacturers, or their suppliers in this publication does not imply or rnnnote approval or disapproval of the product by Argonne National Laboratory or the U. S. Energy Research and Development Administration.

This report has been reproduced directly from the best available copy.

Available from the National Technical Information Service, U. S. Department of Commerce, Springfield, Virginia 22161

Price: Paper Copy $\$ 6.75$ (domestic)

$\$ 9.25$ (foreign)

Microfiche $\$ 2.25$ (domestic)

$\$ 3.75$ (foreign) 


\section{FINAL REPORT}

\section{PHASE ZERO}

Goal Study for the Technical and Economic Evaluation of the Compound Parabolic Concentrator (CPC) Concept Applied to Solar, Thermal, and Photovoltaic Collectors

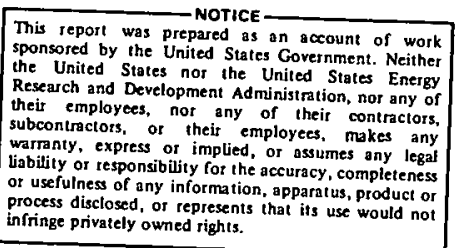

作

infringe privately owned rights.

Prepared for

\section{ARGONNE NATIONAL LABORATORY SUBCONTRACT NO. 31-109-38-3192}


THIS PAGE

\section{WAS INTENTIONALLY LEFT BLANK}


CONTENTS

$\underline{\text { Section }}$

Page

1 INTRODUCTION, SUMMARY AND CONCLUSIONS

$1-1$

1.1 Introduction

$1-1$

1.2 Summary

1-1

1.3 Conclusions

1-4

2 POTENTIAL CPC APPLICATIONS

$2-1$

2.1 Residential and Commercial

2-1

2. 2 Industrial Process Heat

2-15

3

ANL PROGRAM SUMMARY

3-1

3. 1 Background

3-1

3. 2 Laboratory Prototype Testing

3-1

3. 3 ANL Collector Test Facility

3-5

3. 4 Theoretical Performance Studies

3-6

4 CPC MASS PRODUCTION

4-1

4. 1 Design

1-1

4. 2 Manufacturing

4-8

4. 3 Cost and Performance

4-11

5

A COMPARISON OF SOLAR COLLECTORS

5-1

5.1 Introduction

5-1

5.2 The Compound Parabolic Concentrator

5-4

5.3 The Flat Plate Collector

5-13

5. 4 Concentrating Collectors

5-20

5. 5 A Summary Comparison

5-27

6 CONVENTIONAL ENERGY COMPETITION

6-1

6.1 General

6-1

6.2 Oil and Gas

6-1 
6.3 Propane - Special Case

6.4 Coal

$6-3$

6. 5 Summary - Current Price Levels

$6-3$

6.6 Projections, 1980 to 1985

$6-4$

7 INDUSTRY INVOLVEMENT

$7-1$

7.1 Introduction

7-1

7.2 Description of the Building Industry

7-1

7. 3 Solar Energy and the Building Industry

7-7

8 PRIORITIES FOR DEVELOPMENT PROGRAMS

8. 1 Priorities for Photothermal Collector Development Program

8. 2 Photovoltaic Collector Development

\section{Appendix}
A Statement of Work
A-1
B Examples of Process Heat Applications of the CPC Design Concept
B-1
C Examples of Competitive Commercial Solar Space Heating Application
C-1
D Glossary of Important Technical Terms
D-1
E Bibliog raphy
E- 1 
ILLUSTRATIONS

Figure

$\underline{\text { Page }}$

2-1 CPC Flat Plate Solar Collector 2-2

2-2 Collector Efficiency Curve 2-5

2-3 Typical Receiver Temperature Ranges for

Selected Applications $\quad 2-5$

2-4 Solar Rankine Heat Pump 2-7

2-5 Rankine Heat Pump - Battelle 2-8

2-6 Solar Absorption Cooling System 2-10

2-7 Direct Exchange Solar Heating with Solar

2-8 Photovoltaic Heat Pump . 2-14

3-1 Computed Irradiation Distribution Across Exit

Aperture Compound Parabolic Concentrator (CPC) 3-3

4-1 Cre Collector with Keceiver Within 'l'rough 4-6

4-2 Conventional Fuel Costs Used in General Electric Study

4-3 Geographic Centers Where Solar Systems Using Non-Concentrating Collectors Are or Are Not Economic in 1980 (Ref. 48)

4-4 Solar Energy Conversion System Model 4-16

4-5 Incremental Cost Versus Efficiency for CPC Solar Collectors

5-1 Cross Section of the Basic Optical Element of the CPC (Ref. 10)

$5-3$

5-2 Seasonal Collector Orientations (Ref. 131) 5-6

5-3 Three Hybrid Collectors Using the CPC As a Secondary Stage in Two-Stage Line Focus (Ref. 131) 5-7

5-4 Solar Collector Efficiency 5-10

5-5 Computed Hourly Performance for a CPC (Ref. 44) 5-11

5-6 Variations of Flat Plate Collector Design (Ref. 7) 5-14 
5-7 Theoretical Flat Plate Collector Efficiencies (Ref. 36)

5-8 Experimental Efficiencies of a Flat Plate Collector (Ref. 68)

5-9 Diurnal Variation of Theoretical Efficiency for a Flat Plate Collector With a Selective Surface and Cover (Ref. 104)

5-10 Radiation Received on a Normal Surface and a Horizontal Surface in Late October at Madison, Wisconsin - Latitude $43^{\circ} \mathrm{N}$ (Ref. 37)

5-11 Stationary Spherical Concentrator With a Moving Receiver (Ref. 109)

5-12 Moderately Concentrating Grooved Collector (Ref. 59)

5-13 A Comparison of Collector Efficiencies for Various Collector Designs (Ref. 59)

5-14 A Comparison of Efficiencies as a Function of $\Delta T$ (Receiver Temperature Minus Air Temperature) for Four Collector Designs

5-15 Efficiency Curve for the Honeywell Parabolic Trough Collector in the East-West Orientation $570^{\circ} \mathrm{F}$ Receiver Temperature (Ref. 83)

5-16 Efficiency Curve for the Honeywell Parabolic Trough Collector in the North-South Orientation $570^{\circ} \mathrm{F}$ Receiver Temperature (Ref. 83)

6-1 Fuel Price Projection for Residential, Commercial, and Industrial Heating 
TABLES

Table

Page

2-1 Residential and Commercial Solar Systems

$2-3$

2-2 Applications by Industry and Grade of Heat

$2-20$

5-1 Total Heat Losses in Btu/ft-2 $\mathrm{hr}^{-1}$ for Flat Plate and CPC as Function of Concentration and

Absorber Temperature

$5-9$

5-2 Optical Efficiencies of Three CPC Designs (X3, X5, X10) as a Function of Percentage of Global Radiation that is Diffuse

5-3 Stationary Collectors

$5-30$

5-4 Diurnal Tracking Collectors

$5-31$ 
Section 1

INTRODUCTION, SUMMARY AND CONCLUSIONS

\subsection{INTRODUCTION}

This report presents the results of a quick, six-week technical and economic evaluation of the compound parabolic concentrator (CPC) solar collector. The purpose of this effort is to provide an initial phase of a goals study that is directed toward recommending relative priorities for development of the compound parabolic concentrator concept. The findings of this study are of a very preliminary nature. Conclusions based on study findings at this depth should be considered preliminary and subject to revision and review in later phases.

\subsection{SUMMARY}

The study identifies potential markets and gives examples of specific applications for the CPC solar collector. Residential, commercial and industrial markets are considered. The literature indicates that industrial process heat applications will be of secondary importance to residential and commercial space conditioning applications in the near-term future. In particular, CPC solar collectors appear compatible with absorption cooling equipment, Rankine engine driven generators and air conditioning compressors, and photovoltaic devices for residential and commercial space conditioning.

The present state of development of the CPC solar collector is described in the study in a brief review of Argonne National Laboratory's current CPC program. Six empirical tests are being conducted 
on laboratory prototype devices and extensive theoretical analyses of the CPC concept are being made.

To date little has been accomplished toward designing a mass producible, commercial CPC solar collector - a task of significant importance for future work. The study touches on three aspects of mass production: design, manufacture and costs. The literature sets 20 years as an acceptable design lifetime for solar collectors. Throughout this prescribed life, CPC solar collectors should be designed to operate at maximum efficiency to offset the potentially high costs of these devices. Brief discussions of possible designs and.materials for covers, reflectors, receivers, insulation, frames, seals and adhesives are presented in the study. The final product should be structurally integrable panels with adequate strength, durability and fire-retardance to supplant major portions of structure in accordance with applicable building codes.

The economics of solar collectors depend on their particular application on competing conventional fuel costs and on site-specific climatological factors. The CPC solar collector has demonstrated a higher efficiency thain non-concentrating tlat plate collectors for applications requiring heat at temperatures above $150^{\circ} \mathrm{F}$ (e. g., absorption air conditioners and Rankine engines). This added efficiency permits CPC collector costs to be higher than the costs. of less efficient collectors and still maintain an equivalent market capture potential for these higher temperature applications. The study presents a methodology for determining economic costs for mass-produced CPC solar collectors. Included are brief discussions of competing energy costs of coal, gas, oil and electricity and brief reviews of published collector costs and their respective market capture potentials for specific applications in specific geographic centers. 
The study presents a technical comparison of the performance of the CPC solar collector to that of two other basic collector design categories: the stationary flat plate collector and the tracking concentrating collector. Collector efficiency and receiver temperature are used as the primary measures of collector performance in the comparison. Due to the CPC's concentrating ability, higher receiver temperatures are possible with the CPC collector than with flat plate collectors. In addition, because of the reduced receiver area in the CPC collector, losses from the receiver at higher temperatures are less than in flat plate collectors and, therefore, its efficiency is higher. A distinguishing feature of the CPC is its ability to collect radiation within a range of incidence angles (referred to as its "acceptance angle"). By comparison, concentrating collectors focus only normal radiation and, therefore, must track the sun. Another feature of the CPC collector is its design flexibility. CPC's with high concentration ratios are preferable for applications requiring high receiver temperatures such as absorption air conditioning and Rankine engines; conversely, wide acceptance angles can be selected at the expense of concentration ratio in CPC's designed for non-tracking applications.

Finally the CPC solar collectors will have to be introduced to, and accepted by, the building construction industry. The study looks at the device as a potential innovation in the building industry. Sociological and technological factors and associated problems of introducing such an innovation are anticipated and briefly discussed. Some of these factors are methodological, some political and others are unique to the housing industry, such as concern for aesthetics in designing homes. 


\subsection{CONCLUSIONS}

As stated earlier, the purpose of this six-week study is to provide an initial phase of a developmental goals study for the CPC solar collector. At this cursory level-of-effort, any conclusions are of a very preliminary nature and are subject to review and revision in later phases.

Preliminary conclusions at this early stage appear to be as follows:

- The goals study should be continued in significantly greater depth to direct CPC solar collector development.

- Residential and commercial solar applications seem to offer greater near-term potential than do industrial process heat applications.

- In particular, absorption air conditioning, Rankine engine driven generators and air conditioning compressors, and photovoltaic devices for residential and commercial space conditioning applications seem to be compatible systems with CPC solar collectors. CPC collector development should be coordina ted with the development of the principal ancillary devices of these systems.

- Design and manufacturing methods required for the economic mass production of CPC solar collectors should be investigated. The collectors must be durable, efficient and of low cost.

- A 20-year design lifetime appears to be a minimum requirement for solar collectors. 
- The economics and market potential of CPC solar collectors depends on local climatological factors, specific applications, competing fuel costs, and acceptance by the building industry. All of these factors should be investigated further to provide marketing goals.

- To promote market acceptance of the CPC collectors, the panels should be integrable into building structures and should satisfy applicable building codes.

- Once the market potential is determined, a plan should be developed for the dissemination of technical and economic data to potential fabricators, distributors, dealers, builders and consumers. 
Section 2

POTENTIAL CPC APPLICATIONS

\subsection{RESIDENTIAL AND COMMERCIAL}

Because of its wide angle of acceptance, the CPC can concentrate solar energy without diurnal tracking of the sun making it particularly well suited for use in residential and commercial applications as (a) a source of relatively high temperature $\left(150-400^{\circ} \mathrm{F}\right)$ heat or (b) an optical concentrator to reduce surface area requirements of photovoltaic cells. Because they are nontracking, the concentrators can be incorporated into flat panel collector configurations (as shown in Figure 2-1), then integrated into building structures in the same manner as nonconcentrating flat plate collectors. Seasonal tilt adjustment (if required) can be accomplished by adjusting the orientation of the CPC's themselves within the collector frame (similarly to a venetian blind adjustment) without disturbing the integrated collector-to-building interface.* This problem of seasonal adjustment is further discussed in Section 5 of this report.

On the basis of current literature (Ref. $7,48,97, \cdot 116,125$ ) systems for. comfort heating, comfort cooling, and domestic hot water heating were assumed to provide the most feasible residential and commercial applications of solar energy. These three types of systems account for $19 \%, 5.2 \%$, and $4 \%$, respectively, of the national energy consumption. Table 2-1 describes 21 solar systems that are designed to utilize flat plate solar collectors to provide these three functions, either separately or collectively. Seven solar systems from this table were selected as potential applications of CPC rathe $r$ than nonconcentrating flat plate collectors for reasons discussed below and in Section 5 .

* In using this tilt method, spaces will have to be allowed be tween the CPC troughs to prevent shadowing by adjacent troughs. This results in a collector, surface area somewhat larger than the effective aperture area. 


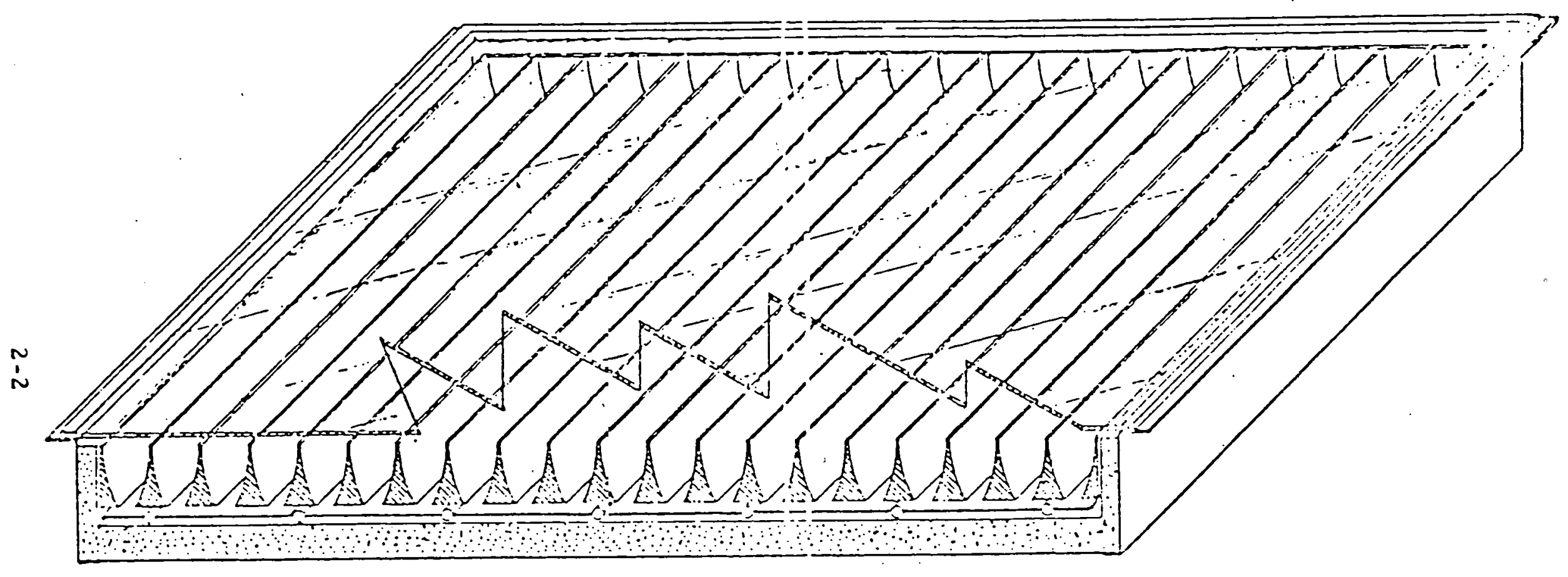

Figure 2-1. CPC Flat Plate Solar Collector 
Table 2-1. Residential and Commercial Solar Systems

\begin{tabular}{|c|c|c|c|c|c|c|c|c|c|c|c|c|c|}
\hline & System & $\begin{array}{l}\text { Sola } \\
\mathrm{HTC}\end{array}$ & $\begin{array}{l}\text { r Func } \\
\text { CLG }\end{array}$ & $\begin{array}{l}\text { ction } \\
\text { CW }\end{array}$ & Status & $\begin{array}{l}\text { Collector } \\
\text { Temp. }\left({ }^{\circ} \text { F }\right)\end{array}$ & $\begin{array}{l}\text { Collector } \\
\text { Fluid }\end{array}$ & Storage & Comments & CPC Utility & Recommendation & $\begin{array}{l}\text { im'd } \\
\text { PC } \\
\text { ication }\end{array}$ & References \\
\hline 1 & The rmosyphon Water Heater & & & - & C.A. & $115-150$ & Water & $\begin{array}{l}\text { Hot } \\
\text { Water }\end{array}$ & $\begin{array}{l}\text { No pump req'd:Subject to freeze-ups; } \\
\text { Collectors must be below storage }\end{array}$ & $\begin{array}{l}\text { Collector temperature too } \\
\text { low to justify CPC cost }\end{array}$ & Poor CPC Application & & $(48,116,125)$ \\
\hline 2 & Pumped Water Heater & & & - & C.A. & " & Water & $"$ & Subject to freeze-ups & " & " & & $(48,116,125)$ \\
\hline 3 & Swimming Pool Heater & & & $\bullet$ & C. A. & BO- 100 & Pool w. & Pool & Subject to freeze-ups & $"$ & & & Mfr's literature \\
\hline 4 & $\begin{array}{l}\text { Binary Cycle Thermosyphon } \\
\text { Water Heater }\end{array}$ & & & - & C. A. & $115-150$ & H. T. L. & $\begin{array}{l}\text { Hot } \\
\text { Water }\end{array}$ & $\begin{array}{l}\text { No pumps req'd; collectors } \\
\text { must be below storage }\end{array}$ & $"$ & " & & $(48,116,125)$ \\
\hline 5 & $\begin{array}{l}\text { Binary Cycle Pumped } \\
\text { Water Heater }\end{array}$ & & & - & C.A.' & $"$ & H. T. L. & $"$ & & $"$ & $"$ & & $(48,116,125)$ \\
\hline 6 & Direct Exchange Heating & - & & - & C. A. & $130-200$ & H. T. L. & $\begin{array}{l}\text { H.L. } \\
\text { or P.C. }\end{array}$ & $\begin{array}{l}\text { Can ase panel radiators, base- } \\
\text { boa rt convectors, or transfer } \\
\text { to forced air }\end{array}$ & $"$ & " & & $(48,116,125)$ \\
\hline 7 & Direct Air Heating & - & & & C. A. & $"$ & Air & H.S. & $\begin{array}{l}\text { Requires ducting to collectors, } \\
\text { larger collector beat transfer } \\
\text { a rea and larger storage volume } \\
\text { than liquid system }\end{array}$ & $"$ & $"$ & & $(48,116,125)$ \\
\hline 8 & Liquid Source Heat Pump & - & & & C. A. & $60-80$ & H. T. L. & $\begin{array}{l}\text { H. L.or } \\
\text { P.C. }\end{array}$ & $\begin{array}{l}\text { May allow cheaper, } 1 \text {-glass oollector } \\
\text { and various atorage media }\end{array}$ & " & $"$ & & (29) \\
\hline 9 & Air Source Heat Pump & - & & & C. A. & $"$ & Air & H.S. & (see 1) & " & $"$ & & $(48,116,125)$ \\
\hline 10 & Solar Rankine Heat Pump & $\bullet$ & - & - & A. $T$. & $200^{+}$ & H.T. L. & $\begin{array}{l}\text { H. L.or } \\
\text { P.C. }\end{array}$ & $\begin{array}{l}\text { Requires advanced, low-friction } \\
\text { rotary expander }\end{array}$ & $\begin{array}{l}\text { CPC more efficient at these } \\
\text { temperatures than non- } \\
\text { concentrating collectors }\end{array}$ & $\begin{array}{l}\text { Potential for CPC if } \\
\text { rotary expander commer - } \\
\text { cially available }\end{array}$ & - & (48, 116. 125) \\
\hline 11 & Rankine Heat Pump: Battelle & - & - & - & A.. $\mathrm{T}$. & " & H. T. L. & $\begin{array}{l}\text { H. L.or } \\
\text { P.C. }\end{array}$ & $\begin{array}{l}\text { Requires advanced rotary vane } \\
\text { expander/compressor }\end{array}$ & $"$ & $\begin{array}{l}\text { Potential for CPC if rotary } \\
\text { device comm. available }\end{array}$ & - & (46) \\
\hline 12 & $\begin{array}{l}\text { Lithium-Bromide } \\
\text { Absorption Cooling }\end{array}$ & & - & - & C.A. & $190-210$ & H. T. L. & $\begin{array}{l}\text { H. L.or } \\
\text { P.C. }\end{array}$ & Requires cooling tower & " & Potential for CPC & - & $(48,116,125)$ \\
\hline 13 & $\begin{array}{l}\text { Aqua-Ammonia Absorption } \\
\text { Cooling }\end{array}$ & & & - & S. A. T & $250-350$ & H. T. L. & $\begin{array}{l}\text { H. L.or } \\
\text { P.C. }\end{array}$ & $\begin{array}{l}\text { No cosling tower required. Hot } \\
\text { water fired absorption device not } \\
\text { on market at present }\end{array}$ & $"$ & $"$ & - & $(21,56,71,80)$ \\
\hline 14 & Off-Peak Absorption Cooling & & - & & C. A. & 210 & H. T. L. & Chilled & $\begin{array}{l}\text { Limited use area; requires oversized } \\
\text { chiller \& night reradiation from } \\
\text { collector }\end{array}$ & $\begin{array}{l}\text { CPC more efficient but it is, } \\
\text { by design, a poor re-radiator }\end{array}$ & Poor CPC Application & 1 & $(48,116,125)$ \\
\hline 15 & $\begin{array}{l}\text { Solar Source Heat Pump- } \\
\text { post storage }\end{array}$ & - & & - & C.A. & $60-80$ & H. T. L. & $\begin{array}{l}\text { H. L.or } \\
\text { P.C. }\end{array}$ & $\begin{array}{l}\text { Requires oversized heat pumps: } \\
\text { Higher storage losses }\end{array}$ & $\begin{array}{l}\text { Collector temperature too } \\
\text { low to justify cost }\end{array}$ & " & & $(48,116,125)$ \\
\hline 16 & $\begin{array}{l}\text { Solar Source Heat Pump- } \\
\text { dual storage }\end{array}$ & - & & - & C. A. & $"$ & H. T. L. & $H \& C$ & $\begin{array}{l}\text { Expensive storage; Use night re- } \\
\text { radiation from collectors }\end{array}$ & $\begin{array}{l}\text { Collector temperature too low } \\
\text { plus CPC is poor reradiator }\end{array}$ & $"$ & & $(48,116,125)$ \\
\hline 17 & $\begin{array}{l}\text { Heat Pump-Solar Source } \\
\text { Heating \& Solar Rankine } \\
\text { Cooling }\end{array}$ & - & - & & A. $\mathrm{T}$. & $\begin{array}{c}60-801 \\
200^{+}\end{array}$ & H. T. L. & H. L. & $\begin{array}{l}\text { Requires advanced low-friction } \\
\text { rotary expander }\end{array}$ & $\begin{array}{l}\text { CPC more efficient than non- } \\
\text { concentrating collectors for } \\
\text { croling function but less effi- } \\
\text { cient for beating function }\end{array}$ & $\begin{array}{l}\text { Potential, but System } 10 \\
\text { would be preferable }\end{array}$ & & $(48,116,125)$ \\
\hline 18 & Photovoltaic Heat Pump & - & - & - & A. T. & $60-80$ & H. T. L. & $\begin{array}{l}\text { H. L.or } \\
\text { P.C. }\end{array}$ & $\begin{array}{l}\text { Requires advanced photovoltaic cells } \\
\text { (now expensive); uses cooling water } \\
\text { from cells as heat pump source }\end{array}$ & $\begin{array}{l}\text { Concentration useful to } \\
\text { reduce cell area and cost }\end{array}$ & $\begin{array}{l}\text { Potential for CPC if } \\
\text { photovoltaic cell cost } \\
\text { reduced }\end{array}$ & - & - \\
\hline 19 & $\begin{array}{l}\text { Direct Exchange Heating with } \\
\text { Li-Br Absorption Cooling }\end{array}$ & - & & & C. A. & $130 / 210$ & H. T. L. & H. L. & Requires cooling tower & $\begin{array}{l}\text { CPC efficiency equals or } \\
\text { exceeds non-concentrating } \\
\text { collector at these temps. }\end{array}$ & Potential for CPC & - & $(48,116,125)$ \\
\hline 20 & $\begin{array}{l}\text { Direct Exchange Heating with } \\
\mathrm{NH}_{3} \text { Aboorption Cooling }\end{array}$ & - & - & - & C. A. & $\left|\begin{array}{l}130-200 / \\
250-350\end{array}\right|$ & H. T. L. & H. L. & No cooling tower required & . $\quad:$ & $"$ & - & $(21,56,71,80)$ \\
\hline 21 & $\begin{array}{l}\text { Direct Exchange Heating with } \\
\text { Solar Rankine Vapor Comp- } \\
\text { ression Cooling }\end{array}$ & | & - & - & A.T. & $130 / 200^{+}$ & H. T. L. & H. L. & $\begin{array}{l}\text { Requires advanced low-friction } \\
\text { rotary expander }\end{array}$ & $"$ & $\begin{array}{l}\text { Potential but system } 10 \\
\text { would be preferable }\end{array}$ & & $48,116,126)$ \\
\hline
\end{tabular}
Key to Symbolg:
A.T.: Advanced Technology; C. A.: Commercially Available; H. L.: Heated Liquidi. H.S.: Heated Stone; H \& C: Heated \& Chilled
H. T. L.: Heat Transfer Liquid; P.C: Phase Change Material; S. A. T.: Semi Advanced Technology 
Flat panel collectors that incorporate CPC's are inherently more costly than non-concentrating flat plate collectors with one or two cover glasses. The increased cost may be justified for applications requiring concentrated solar energy to eithe $r$ (a) provide a heat exchange fluid at higher temperatures than are efficiently. attainable with nonconcentrating flat plate collectors or (b) reduce cell surface area requirements in photovoltaic applications. The increased efficiency of CPC collectors over non-concentrating collectors at high $\left(>150^{\circ} \mathrm{F}\right)$ heat absorber plate temperatures is illustrated in the curves in Figure 2-2 (Ref. 10, 31). These curves show collector efficiency (i. e., the percent of heat output to the total amount of radiant energy falling on the collector)versus absorber temperature for various collector configurations. Also shown are absorber temperature requirements for various residential and commercial flate plate collector applications (Figure 2-3). From these curves, it appears that the following solar systems require absorber. temperatures at which the CPC flat panel collector operates significantly more efficiently than the simpler nọ-concentrating flat plate collectors:

- Solar Rankine cycle heating and/or cooling systems

- Lithium-bromide absorption coollng systerrs

- Aqua-ammonia absorption cooling systems

Seven types of systems were selected from Table 2-1: the solar Rankine heat Pump; the Rankine heat pump: Batt:lle; lithium-bromide absorption cooling; aqua-ammonia absorption cooling; direct exchange heating with absorption cooling; the photovoltaic heat pump. Each of these systems, with the exception of the photovoltaic heat pump, consists of one or more of the three solar systems listed above; and each of the se systems is described below. 


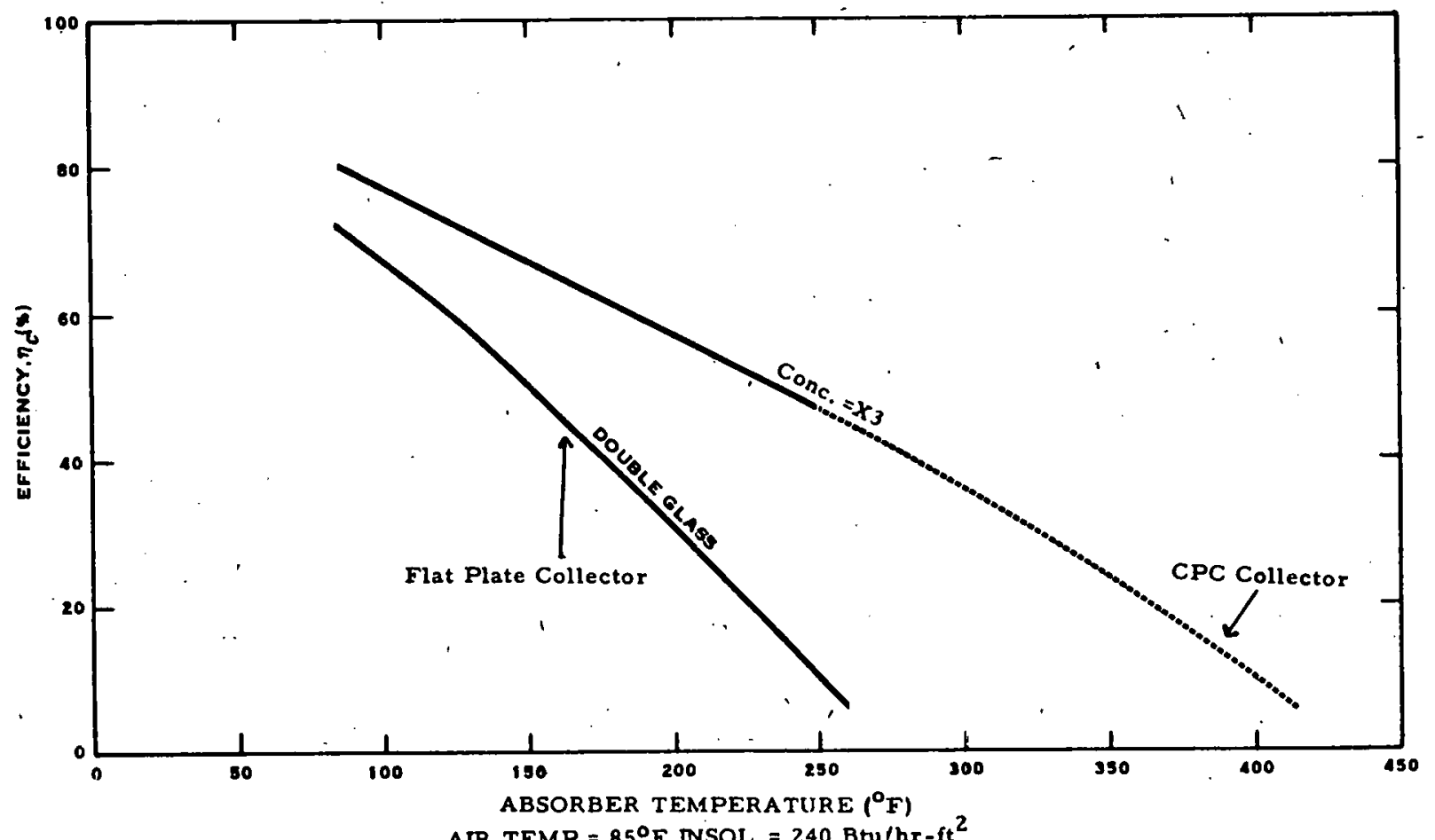

AIR TEMP $=85^{\circ} \mathrm{F}$ INSOL $=240 \mathrm{Btu} / \mathrm{hr}-\mathrm{ft}^{2}$

Figure 2-2. Collector Efficiency Curve

SOLAR HEAT SOURCE HEAT PUMP (DISCUSSED IN TEXT)

PHOTOVOLTAIC CELLS

DOMESTIC HOT WATER SUPPLY

DIRECT EXCHANGE SOLAR HEATING

LI-ER ABSORPTION COOLING

SOLAR RANKINE CYCLES

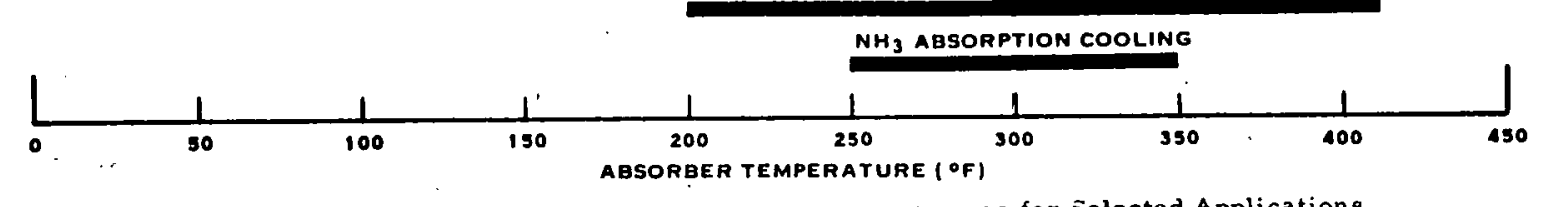

Figure 2-3. Typical Receiver 'l'emperature kanges for Selected Applications 


\subsection{1' Solar, Rankine Heat Pump}

A heat pump is a refrigerant vapor compression device that provides year-round space conditioning. In the winter, the device heats by absorbing heat from outdoor air in a cold refrigerant, "boosting" the heat to higher temperature by compression, and discharging the hoat to the conditioned space. In the summer, the device cools and dehumidifies by absorbing heat from the conditioned space, "boosting" it by réfrigerant compression, and discharging it to outdoor air (see Ref. 6, p. 467). The solar Rankine heat pump (see Figure 2-4) uses a solar powered heat engine to drive the heat pump's compressor.

The heat pump and all other components of the system shown in Figure 2-4 are at present commercially available with the exception of the heat engine. Considerable research has been devoted to the development of low-friction engines to effectively utilize the low-grade heat that can be extracted from flat plate solar collectors.(Ref. 20; 45, pp. 170-176; 61, pp.7-10;64, pp.83-100; 79; 112; 113, pp. 89-93), Rankine cycle reciprocating engines, turbo-expanders, and Stirling cycle engines have been examined in some detail for use with solar collectors. One such rotary-vane expander has demonstrated over 1000 hours of heat pump operation at $10 \%$ thermal cycle efficiency with $200-250^{\circ} \mathrm{F}$ boiler temperatures. If the boiler temperatures are raised to $250^{\circ}-350^{\circ} \mathrm{F}$, the engine's efficiency is expected to reach $12-14 \%$. This engine could be commercially available by 1980 if a market is demonstrated (Ref. 51).

\section{1.2 Rankine Heat Pump: Battelle}

The solar Rankine heat pump currently being developed at Battelle Laboratories in Columbus is shown schematically in Figure 2-5. It 


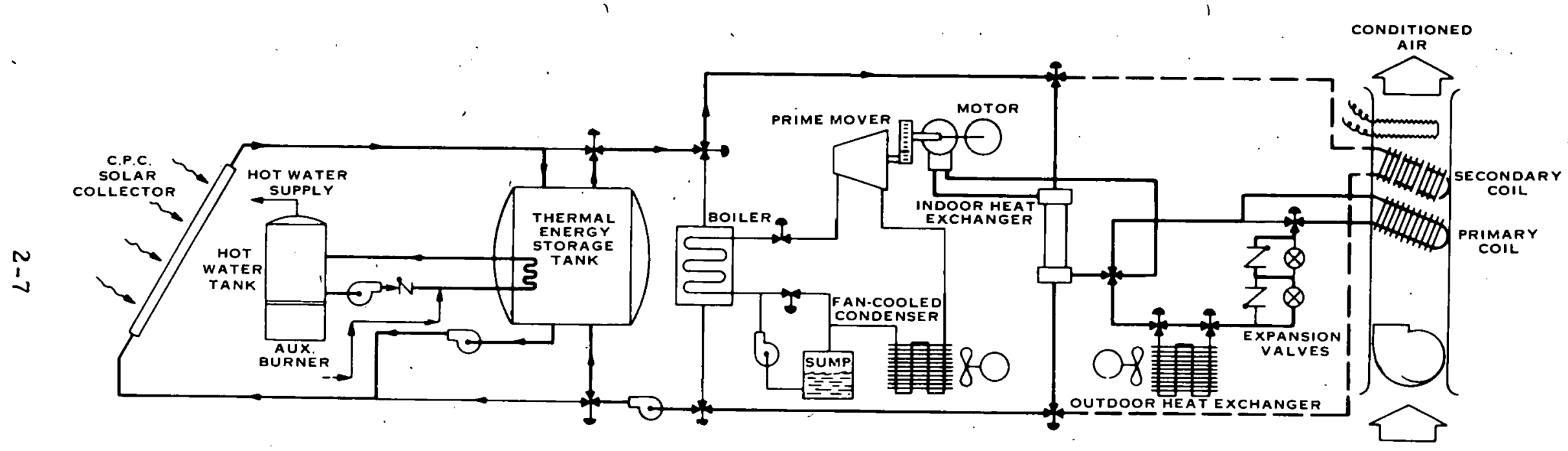

Figure 2-4

Solar Rankine Heat Pump 


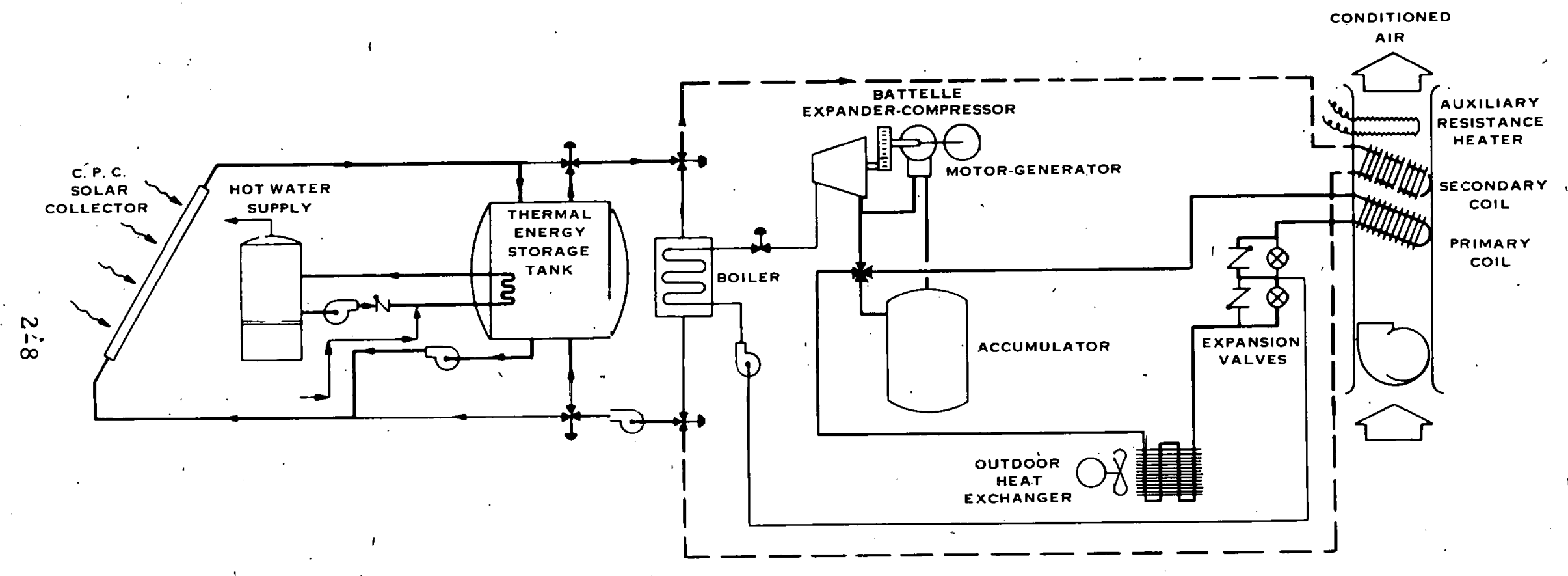

Figure 2-5

Rankine Heat Pump - Battelle . 
uses a unique integrated Rankine driving cycle and vapor compression refrigeration cycle to heat, cool, and dehumidify the conditioned space. The engine and the compressor are mounted on one shaft and both use a common Freon refrigerant charge as a working fluid. Another unique feature of this pump is its experimental rotary vane expander compressor, in which the displacers are "pivoting-tip vanes" that are designed to float against the inner wall of the pump housing such that a hydrodynamic lubricating film is self-generated by the vane tips. The result is very low friction without the use of liquid lubricants (Ref. 77, p. 48). The thermal efficiency of the Rankine driving cycle is reported to be about $10 \%$ with $200^{\circ} \mathrm{F}$ boiler temperature (Kef. 46 ).

\section{1. 3 Lithium-Bromide Absorption Cooling}

Lithium-bromide absorption cooling equipment that uses heat from hot water at about $210^{\circ} \mathrm{F}$ to directly drive a water chiller without mechanical conversion is commercially available in 3-ton and 25 -ton $\mathrm{Btu} / \mathrm{hr}$ sizes $(1$ ton $=12,000 \mathrm{Btu} / \mathrm{hr}$ cooling effect) (Ref. 21,80$)$. The equipment may pe incorporated into a solar cooling system as shown schematically in Figure 2-6. One drawback of the lithium-bromide cycle for residential applications is that a cooling tower is required to maintain an inlet condensing water temperature of $70-85^{\circ} \mathrm{F}$.

\section{1.4 Aqua-Ammonia Absorption Cooling}

Aqua-ammonia absorption cooling resembles lithium-bromide absorption cooling in that it uses heat to directly drive the cooling cycle. The aquaammonia cycle can operate without a cooling tower but requires heat input to the vapor generator at $250-350^{\circ} \mathrm{F}$, significantly hotter than the lithium-bromide cycle, which requires a cooling tower (Ref. 21, 80). Because 

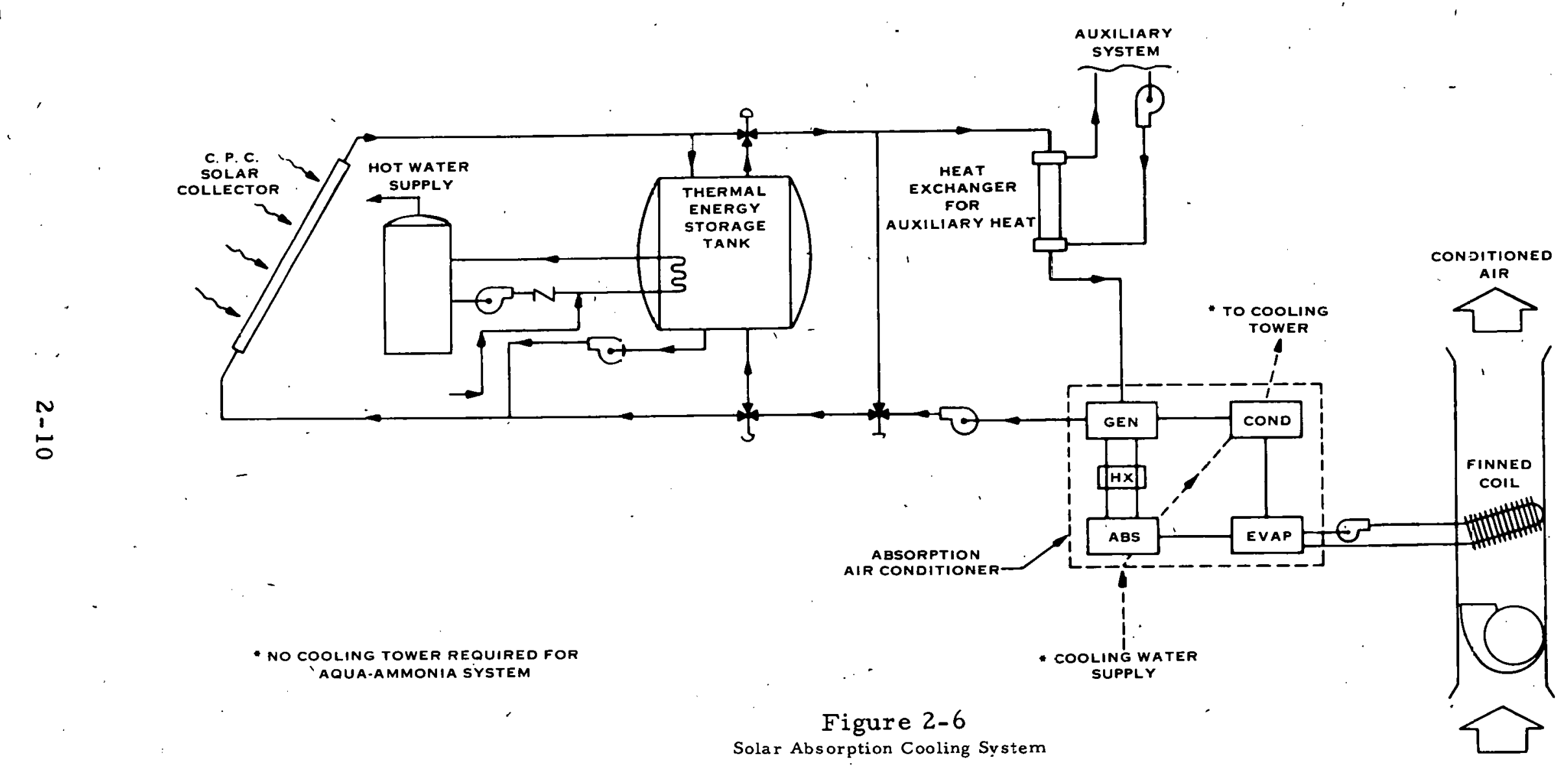

Solar Absorption Cooling System 
- of the poor collection efficiency of non-concentrating flat plate collectors in the $250-350^{\circ} \mathrm{F}$ range, the use of the aqua-ammonia cycle in solar cooling systems has not been actively pursued. However, CPC flat panel collectors appear capable of relatively efficiently collecting heat in this elevated temperature range, and it may now be feasible to design a solar cooling system incorporating CPC collectors with an aqua-ammonia cooler.

Hot-water-fired aqua-ammonia cooling equipment is not commercially available at present. Gas-fired units are available in $3_{-}, 4-, 5-, 10_{-}$, 15-, 20-, and 25-ton sizes and could be converted to hot water firing by modifying the heat transfer design of the vapor generator (Ref. 56,71 ). An aqua-ammonia solar absorption cooling system would have the same design as the lithium-bromide system in Figure 2-6 with the exclusion of a cooling tower. Because it doesn't have a cooling tower, the aquaammonia equipment should cost less than lithium-bromide equipment of the same capacity (Ref. 80).

\section{1. 5 Direct Exchange Heating with Absorption Cooling}

A year-round heating and cooling system may be designed (as shown in Figure 2-7) by using a solar absorption cooling system and including piping to bypass the absorption unit in the heating season to supply solar heated water to a coil in the conditioned air duct. During the cooling season, the lithium-bromide or aqua-ammonia absorption cooling system would function as described earlier. 


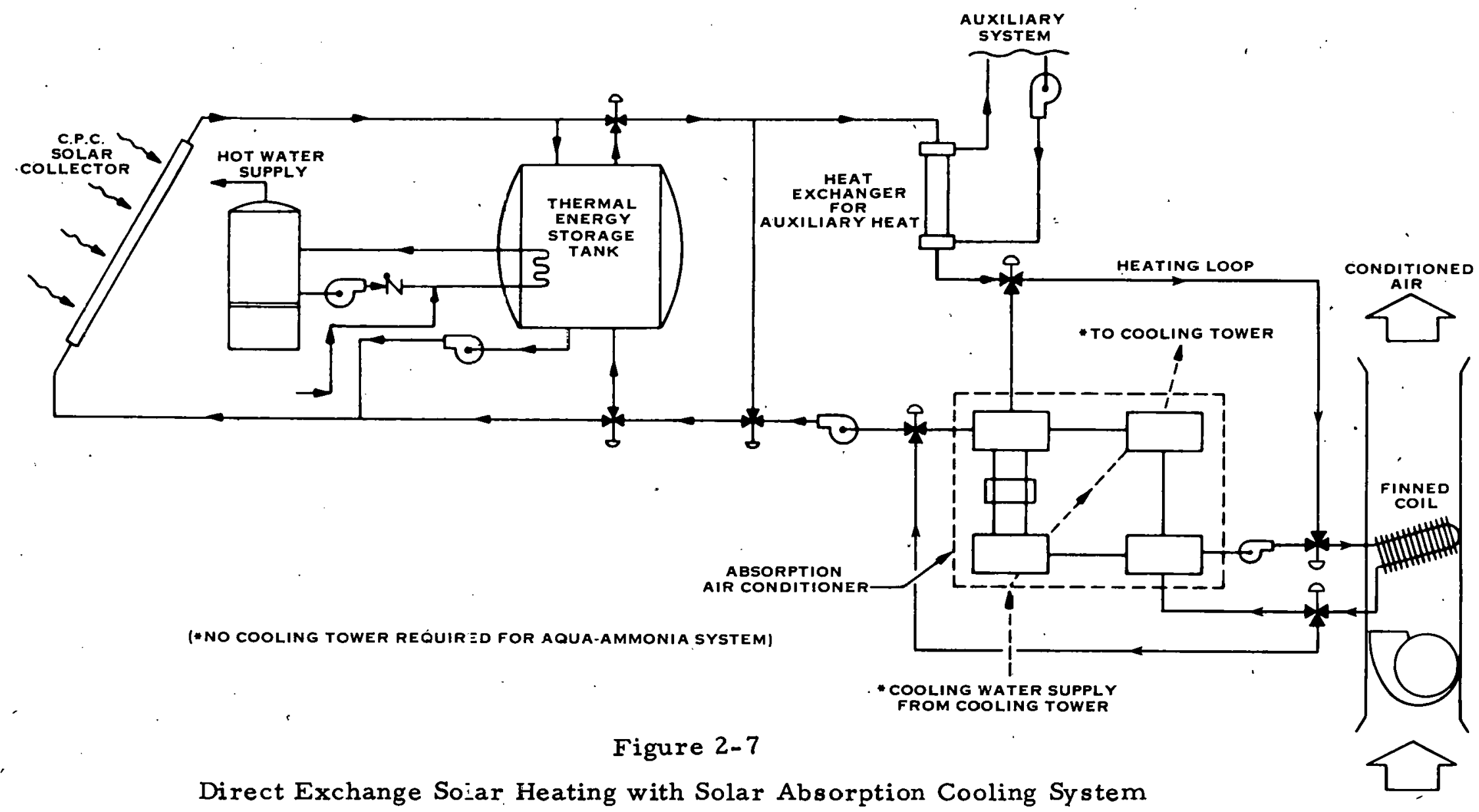




\section{1.6 Photovoltaic Heat Pump}

Electrically driven heat pumps are commercially available in capacities suitable for most residential and commercial applications. By, coupling the electric compressor motor of a heat pump to a solar photovoltaic power cell array, an energy-efficient solar heating ànd cooling system can be developed (see Figure 2-8). In the system shown in Figure 2-8, electric hot water heating is included.

CPC flat panel collectors with photovoltaic cells placed in the focal region can reduce cell surface area by a factor equal to the CPC concentration ratio. At present, silicon photovoltaic cells cost about $\$ 30$ per peak watt for terrestrial-use, but increasing production quantities and implementing ribbon mass production methods now under laboratory development might result in a cell cost of $\$ 5$ per peak watt by 1978 and $50 \xi$ per peak watt by 1983. It has been estimated that $\$ 1$ per peak watt is the threshold cost for cells to be competitive with conventional fuels for building applications (Ref. 101).

Photovoltaic silicon cell efficiency degrades significantly as the cell temperature increases. At the present state of development, the efficiency of a terrestrial silicon cell at $25^{\circ} \mathrm{C}\left(77^{\circ} \mathrm{F}\right)$ is $16.5 \%$. This efficiency drops $0.5 \%$ for each degree centrigrade of cell temperature increase (Ref. 101). Circulating a cooling fluid through tubes in contact wi th the cells may permit maximum cell operating efficiencies to be maintained by removing heat that is concentrated on the cell by the CPC.

Heat pump performance in the heating mode may be enhanced by increasing the temperature at the heat absorbing coil. Low grade $\left(70-80^{\circ} \mathrm{F}\right)$ heated fluid that is removed from the CPC cell array may 


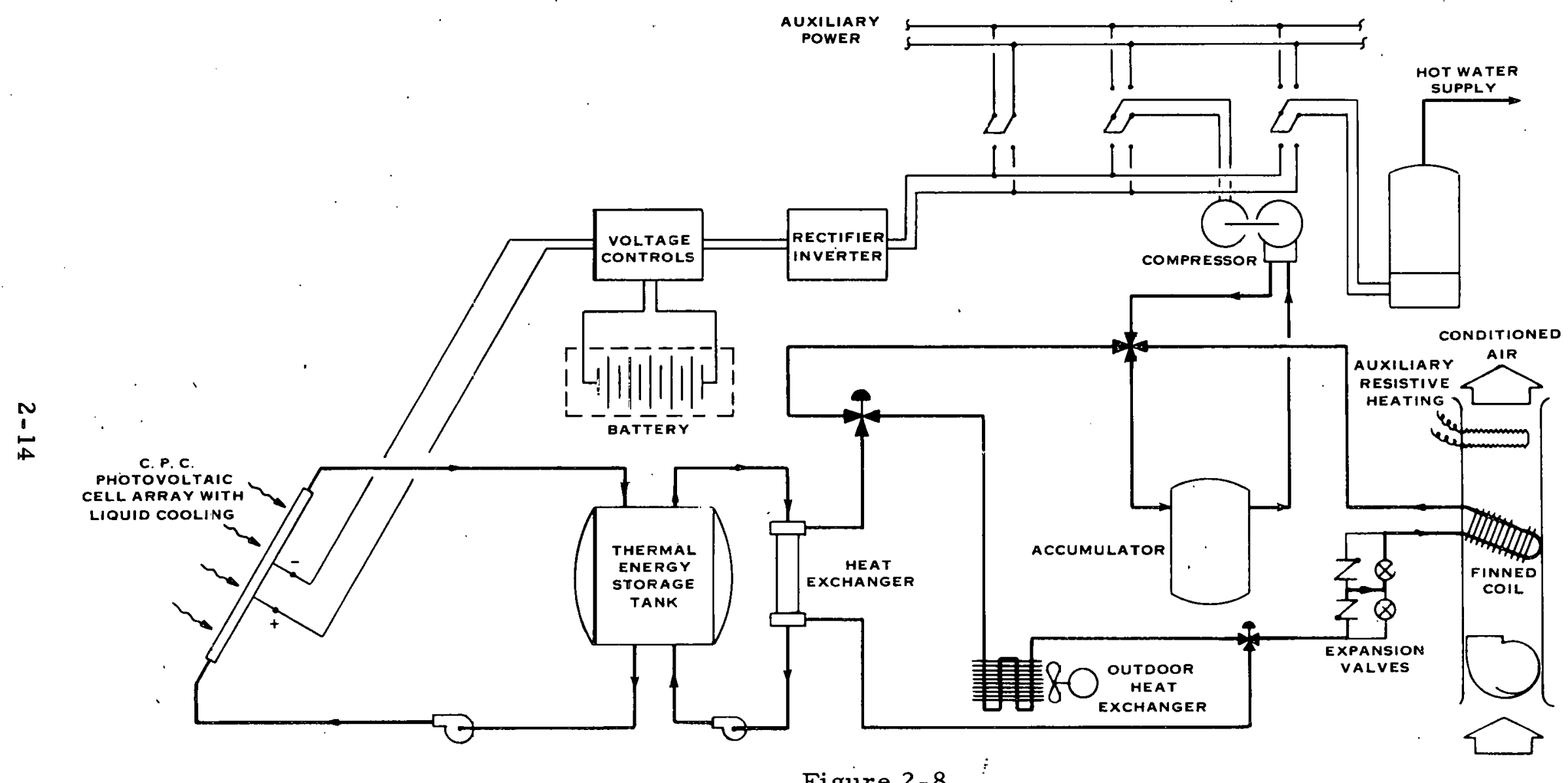

Figure 2-8

Photovoltaic Heat Pump 
be used as such a heat source for the heat pump in the heating mode. Figure 2-8 shows a heat exchanger incorporated into the photovoltaic heat pump system for the purpose of applying this heated fluid to the heat pump. Temperature-controlled valves in the heat pump refrigerant cycle would be designed to switch heat absorption to either the outdoor heat exchanger or to the heat exchanger storage tank - whichever is at the higher temperature.

Dual air/water source heat pumps are not commercially available at present. Such a device is technically feasible as long as needed hardware components (i.e., leak-tight refrigerant switching valves) can be obtained (Ref. 52).

\subsection{INDUSTRIAL PROCESS HEA T}

The original intent of this subsection was to suggest design goals and a sense of priorities for developing the CPC design concept, specifically for process-heat applications. However, with little or no direct indication of possible wide-scale acceptance in the next decace of solar industrial process heat applications, it was not possible to develop design goals. However, design inferences may be drawn from applications analyses which follow.

Any industrial process that requires heat energy, such as process steam at low pressure (steam conditions of $400^{\circ} \mathrm{F}, 250$ psia may represent the upper limit for most $C P C$ applications to consider in . this study), process water under pressure at elevated temperatures, hot air, and other heat transfer fluids, may be considered as a possible application of the CPC collector. The above processes include all forms of heat transfer, refrigeration, and chilling water processes. In evaluating whether the CPC design concept could be considered attractive in such applications, the criteria given below may be employed. 
2.2.1 Selection Criteria for Solar Energy Conversion to rrocess Heat

The selection criteria are as follows:

- Purceived technical characteristics of the solar energy system

- Flexibility in responding 10 time-varying inputs and loads, and the need for supplemental energy supplies from auxiliary, conventional sources

- Sensitivity to weather, earthquakes, and other manifestations of natural phenomena normally expected at sites selected for industrial development. These include cloud cover, snow, ice, hail, etc. Also, collector systems may be vulnerable to natural catas. trophes, such as tornadoes

- Technical reliability of system operation when exposed to an industrial environment (aside from the vagaries of nature) and, in particular, when solar tracking is needed. The environment may produce an accumulation of debris, dust, and visible air pollution. The site may be cubject to vandaliom; accidents, and other damaging occurrences

- Response to the peak-load/baseload requirements of each process

- Thermal storage requirements

- Synergistic effects

- Heat transport mechanisms

- Potential economic viability of the system

- Costs

- Economies of scale

- Estimated competitive pricing of procèss heat, comparing conventional sources to solar. energy 
- Potential for achieving lower collector costs via mass production

- Environmental impacts, socioeconomic acceptability and institutional constraints.

Major questions concerning implementation, zoning codes, sun rights, system ownership, legal issues and subjects peculiar to "solar collector" heat sources have been addressed in a 40-page study report entitled, "The Socio-Legal Problems of Solar Collectors", by Faul Kenyon, J. D. , California Polytechnịc State University, San Luis Obispo, California, par $\overline{\mathrm{t}}$ of Ref. 26.

\subsubsection{Market Penetration}

It was estimated by the MITRE Corporation in December 1973 (Ref. 84) that the use of solar energy for process-heat application will be somewhat less in magnitude compared with projected use of solar energy for the heating and cooling of buildings. Total solar energy conversion to process heat, exclusive of central power generation, is expected to be approximately one-half of the amount used in comfort space conditioning.

For a variety of reasons discovered during the survey of each particular industry category and from the overall views given by the MITRE, Corporation (Ref. 84) at the close of 1973, it was inferred that the potential for process heat-applications of the CPC would not be implemented on a wide scale in the United States in the next decade.

Fragmentation in many industries and the specialized uses for process heat will make it difficult for any one supplier of solar energy collectors to capture more than a small portion of the market in the forsee- 
able future. In some cases, where solar energy becomes econonically feasible, the application of the CPC may be suitable for near-term commercialization. However, no instances are foreseen in this study until 1980 or 1985, when collector optical and heat transfer technology might be advanced sufficiently for wide diffusion of advanced technology to take place. Only one example of an emergent application was identified and is reported in Appendix B, as is the sunbaking application. This last application was conceptualized and reported because it represents the highest grade of heat $\left(425^{\circ} \mathrm{F}\right)$ identified in this study as a potential CPC application.

The solar systems that may be considered for CPC process heat applications, in addition to those identified earlier in this section, were identified as follows:

- Heat Engines - Ormat turbines have operated over a million hours

- Irrigation pumping systems - 15 in Africa, 1000 going into Mexico

- Saline water stills - (conceptual stage)

- Baking ovens - (conceptual stage)

- Wood kiln drying

- Food drying, tunnel/conveyor

- Various steam boilers

Potential applications are listed by Industry Section and by grade of heat required in Table $2-2$.

\subsubsection{Conclusion}

All perceived applications of the CPC design concept for generating 
process heat are considered at this time to be of secondary impor- tance as prospects for near-term commercialization. The primary areas for near term application of the CPC solar collector will be mainly in the space heating and cooling of commercial and residential buildings. 
Table 2-2

Applications by Industry and Grade of Heat

\begin{tabular}{|c|c|c|c|}
\hline Industry Sector & SIC & $\begin{array}{l}\text { Applications for Low } \\
\text { Grade Heat } \angle 212^{\circ} \mathrm{F}\end{array}$ & $\begin{array}{l}\text { Applications for Medium } \\
\text { Grade Heat } 212^{\circ}-400^{\circ} \mathrm{F}\end{array}$ \\
\hline Agricultural production & 01,02 & $\begin{array}{l}\text { Desalination-single stage } \\
\text { still }\end{array}$ & $\begin{array}{l}\text { Desalination-multi stage distillatio } \\
\text { (none are presently commercially" } \\
\text { viable) } \\
\text { Irrigation water pumping }\end{array}$ \\
\hline Agriculture & 09 & Freshwater heating & - \\
\hline Mariculture & 09 & Seawater heating & \\
\hline $\begin{array}{l}\text { Controlled environment } \\
\text { agriculture (greenhouse) }\end{array}$ & 0182 & $\begin{array}{l}\text { Space heating, hydroponic } \\
\text { heating }\end{array}$ & $\begin{array}{l}\text { Cooling at periods of peak } \\
\text { insolation }\end{array}$ \\
\hline Poultry and egg production & 025 & Space heating, incubation & $\begin{array}{l}\text { Cooling at periods of peak } \\
\text { insolation }\end{array}$ \\
\hline Animal husbandry & - & Space heating & $\begin{array}{l}\text { Environmental control for } \\
\text { animals and plants }\end{array}$ \\
\hline Agricultural services & 0723 & Grain drying & $\begin{array}{l}\text { Precooling fruits and vegetables } \\
\text { ice-making, refrigeration }\end{array}$ \\
\hline Special services & & UV concentrated irradiation & Peanut roasting, IR irradiation \\
\hline Construction, concrete & 17,1771 & $\begin{array}{l}\text { Space heating for winter } \\
\text { construction work. }\end{array}$ & $\begin{array}{l}\text { Accelerated curing of concrete } \\
\text { Refrigeration of dams, soils and } \\
\text { foundations }\end{array}$ \\
\hline $\begin{array}{l}\text { Manufacturing of food and } \\
\text { kindred products }\end{array}$ & 20 & $\begin{array}{l}\text { Hot water-washing, air } \\
\text { preheating, drying and } \\
\text { dehydration. Space heating. }\end{array}$ & $\begin{array}{l}\text { Process steam, hot water, } \\
\text { scalding, washing, sterilizing, } \\
\text { freezing and ice-making }\end{array}$ \\
\hline Meat packing & 201 & Curing & $\begin{array}{l}\text { Canning, cooking, refrigera- } \\
\text { tion, freezing, space cooling }\end{array}$ \\
\hline Poultry and egg processing & - & Cleaning & $\begin{array}{l}\text { Canning, , cooking, drying, re- } \\
\text { frigeration, freezing, and space } \\
\text { cooling }\end{array}$ \\
\hline
\end{tabular}


Table 2-2 (Cont'd)

\begin{tabular}{|c|c|c|c|}
\hline Industry Sector & SIC & $\begin{array}{l}\text { Applications for Low } \\
\text { Grade Heat }<212^{\circ} \mathrm{F}\end{array}$ & $\begin{array}{l}\text { Applications for Medium } \\
\text { Grade Heat } 212^{\circ}-400^{\circ} \mathrm{F}\end{array}$ \\
\hline Dairy products & 202 & Pasteurization, space heating & $\begin{array}{l}\text { Ice cream and freezing desserts } \\
\text { Dry milk processing }\end{array}$ \\
\hline $\begin{array}{l}\text { Canning and preserving } \\
\text { fruits and vegetables }\end{array}$ & 203 & Space heating & Blanching and cooking processes \\
\hline Drying fruits and vegetables & 2034 & \multirow{4}{*}{\multicolumn{2}{|c|}{$\begin{array}{l}\text { Food drying, truck \& tunnel } 165^{\circ} \mathrm{F} \\
\text { belt conveyor systems } 200^{\circ} \mathrm{F} \\
\\
\text { Fast freezing of fruits, vege- } \\
\text { tables and juices } \\
\text { Freezing food specialties } \\
\text { Cereal, oil, seed processing } \\
\text { inversión of sugar, flash drying } \\
\text { of starch }\end{array}$}} \\
\hline $\begin{array}{l}\text { Freezing fruits and } \\
\text { vegetables }\end{array}$ & 2037 & & \\
\hline Freezing specialties & 2038 & & \\
\hline Grain, sugar, fats, oils & $\begin{array}{l}204,206 \\
207\end{array}$ & & \\
\hline Baking & 205 & & $\begin{array}{l}\text { Baking bread and cakes in ovens } \\
\text { to } 425^{\circ} \mathrm{F}\end{array}$ \\
\hline Brewing malt beverages & 2082 & . & Steam requir ements \\
\hline Distilling liquors & 2085 & $\cdot$ & Steam requirements \\
\hline $\begin{array}{l}\text { Miscellaneous food } \\
\text { preparation }\end{array}$ & 209 & Space heating & Coffee roasting \\
\hline $\begin{array}{l}\text { Manufacturing ice for com- } \\
\text { mercial and consumer } \\
\text { markets }\end{array}$ & 2097 & 1 & $\begin{array}{l}\text { Freezing of water, unattended ice } \\
\text { vending machine processing }\end{array}$ \\
\hline Textile milling & 22 & Space heating & \\
\hline Pulp and paper making & 26 & & Process steam \\
\hline Chemicals, drugs & 28 & Salt making by evaporation & $\begin{array}{l}\text { Process steam, ovens, } \\
\text { refrigeration }\end{array}$ \\
\hline
\end{tabular}


Table 2-2 (Cont'd)

\begin{tabular}{|c|c|c|c|}
\hline Industry Sector & SIC & $\begin{array}{l}\text { Applications for Low } \\
\text { Grade Heat }<212^{\circ} \mathrm{F}\end{array}$ & $\begin{array}{l}\text { Applications for Medium } \\
\text { Grade Heat } 212^{\circ}-400^{\circ} \mathrm{F}\end{array}$ \\
\hline $\begin{array}{l}\text { Lea ther tanning and } \\
\text { finishing }\end{array}$ & 29 & Spa $=e$ heating & Process steam \\
\hline Public wa rehousing & 422 & Heating for storage space & $\begin{array}{l}\text { Refrigerator warehousing, } \\
\text { freezers and meat lockers, } \\
\text { other space cooling }\end{array}$ \\
\hline Liquid waste disposal & 495 & - & Concentrating liquid wastes \\
\hline Steam supply & 4961 & Ice melting, space heating & $\begin{array}{l}\text { Steam supply utility service, } \\
\text { refrigeration, space cooling }\end{array}$ \\
\hline Irrigation service industry & 4971 & - & Pumping irrigation water \\
\hline $\begin{array}{l}\text { Wholesale trade- } \\
\text { non-durable goods }\end{array}$ & 51 & $\begin{array}{l}\text { Spaze heat for proper } \\
\text { stozage }\end{array}$ & Space cooling, refrigeration \\
\hline Launderies & 721 & Space heating & Wash water and steam cleaning \\
\hline Car washes and steam & 754 & Make-up hot water & Steam cleaning \\
\hline $\begin{array}{l}\text { Health services, hospitals, } \\
\text { clinics }\end{array}$ & 80 & Space heating & $\begin{array}{l}\text { Steam, hot water, sterilization, } \\
\text { space cooling }\end{array}$ \\
\hline $\begin{array}{l}\text { Zoological gardens, } \\
\text { aquaria, etc. }\end{array}$ & 842 & Space heat, hot water & $\begin{array}{l}\text { Radiant heating for climate } \\
\text { simulation and space and water } \\
\text { conditioning as well }\end{array}$ \\
\hline
\end{tabular}




\section{ANL PROGRAM SUMMARY}

\section{1 BACKGROUND}

Argonne National Laboratory and the University of Chicago are performing proof-of-concept investigations of the Compound Parabolic Cuncentrator. The profile curve of the CPC, consisting of two distinct parabolas, has been known for several years in a truncated cone-shaped curved reflector used to concentrate or gather Cherenkov radiation. These conical concentrators are coupled with radiation detectors. Professor Roland Winston, with his associates at ANL and University of Chicago, have, in a sense, "unwrapped" the coned concentrators to form concentrating compound parabolic troughs for the collection of solar energy. Coincidentally, what appears to be an independent but almost simultaneous effort at developing the CPC design concept is taking place in the Soviet Union.

3.2

LABORATORY PROTOTYPE TESTING

The Argonne program has, to date, involved six empirical laboratory tasks plus theoretical studies on the performance of CPC solar collectors (Ref. 9, 10, 131). This work has been at the proof-of-concept level and, as such, has included studies, designs and tests of prototype collectors. To date little has been accomplished toward designing a mass producible, commercial CPC solar collector - a task of significant importance for future work.

The six laboratory tasks undertaken by ANL to date are as follows:

- A CPC with a concentration ratio of 8 was used to concentrate solar radiation on a strip of photovoltaic cells. The CPC reflectors were surfaced with $0.001^{\prime \prime}$ aluminum sheet (commercially marketed as "Alzak" by Alcoa) which has a reflectivity of about 75\%. Losses attributed to surface reflectivity reduced the effective concentration ratio to about 6.4 . It was also found that although the. CPC is a 
non-imaging concentrator, radiation peaks do exist in the fucal region for certain angles of incidence. Figure 3-1 illustrates calculated values of this radiation peaking effect. Such peak effects, however, were less accentuated in empirical studies. A prototype $48 \times 48$ inch CPC flat plate collector was fabricated and tested at ANL in late 1974. The collector assembly (shown in Figure 2-1) consisted of a single plexiglas cover, 20 cast epoxy CPC reflector bars with a concentration ratio of $\mathrm{X} 3$ and a roll-bond aluminum absorber coated with a non-selective black paint. The assembly was contained in an aluminum box insulated on the sides and back. The reflectors were surfaced with vacuum deposited aluminum having a reflectivity of $88 \%$ over the sola $r$ spectrum.

A report of the design and testing of this X3 CPC prototype collector has been published by ANL (Ref. 10). Results of the tests have been extrapolated by ANL to arrive at the expected performance shown in Figure 2-6. The expected performance of this X3 CPC appears well suited for an energy source for the absorption cooling and solar Rankine systems discussed in Section 2.1 of this report.

- Two prototype CPC solar collector troughs having a concentration ratio of $\mathrm{X} 10$ were fabricated and tested at ANL during January-May 1975. Each collector was 12 inches wide at the aperture, 36 inches high from the focal region to the aperture, 1. 2 inches wide at the focal region and 48 inches long. The reflector surfaces were "Alzak" aluminum sheets having a reflectivity of $75 \%$ over the solar spectrum. The heat receiver in each trough was a non-selective black tube of 


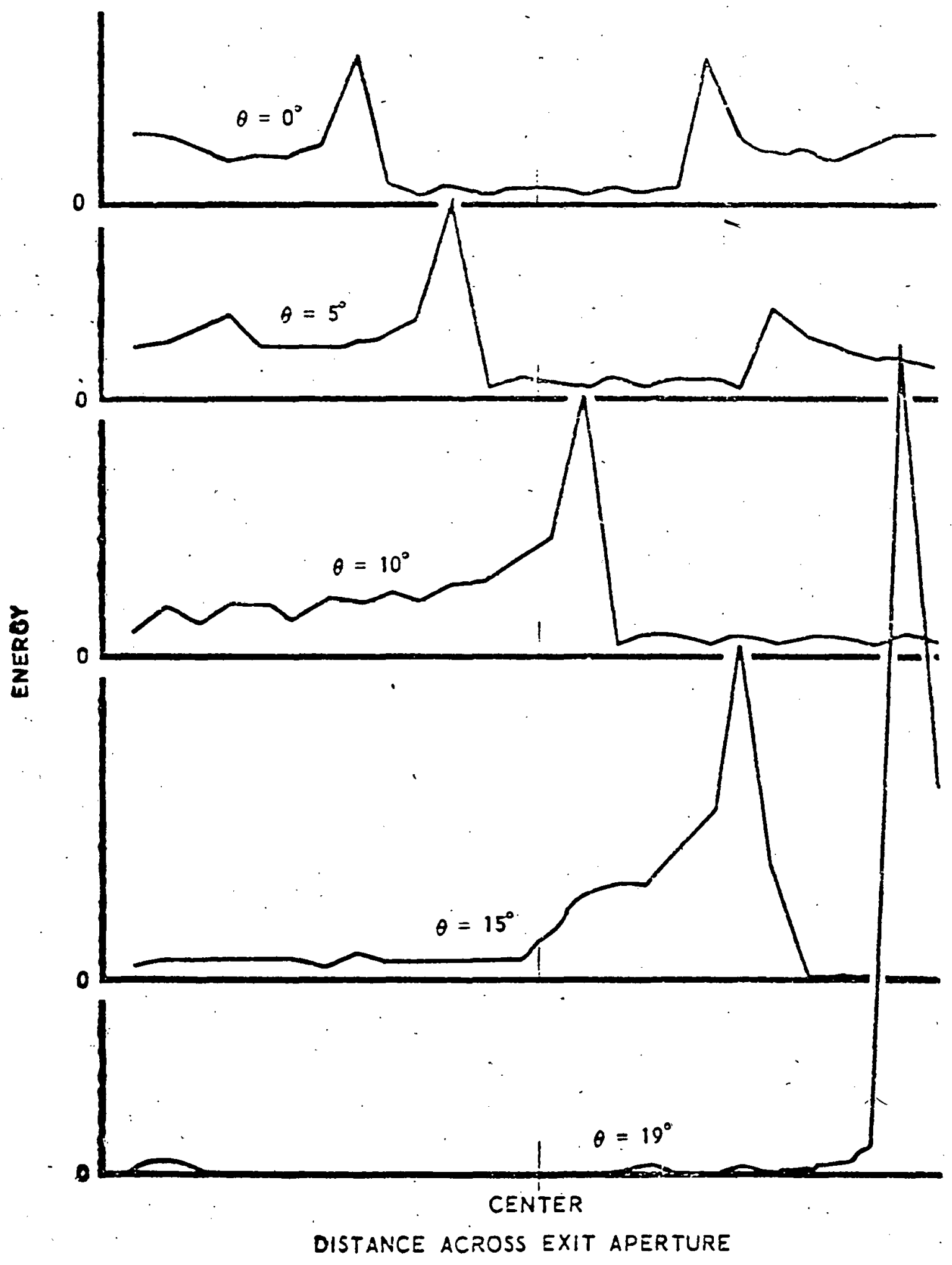

Figure 3-1. Computed Ir radiation Distribution Across Exit Aperture Compound Parabolic (Concentrator CPC) 
$3 / 8$ inch diameter brazed onto a $1 \frac{1}{4}$ inch copper tube cut in half lengthwise to form a semi-cylindrical base at the bottom of the trough.

The results of the X 10 CPC tests (Ref. 9) indicate that this device is significantly more efficient than flat plate collectors for high temperature applications but, because of a limited incident radiation acceptance angle of $10^{\circ}$, frequent reorientation of the concentrator is likely to be required.

- Using cast epoxy CPC reflector bars from the earlier X3 collector, a prototype collector was fabricated with a serpentine tube receiver in the focal region in place of the previous roll-bond sheet. This configuration was designed to reduce the surface area of the receiver thereby reducing heat losses attributed to infrared reradiation. Testing was underway in June 1975 and preliminary results indicate that: (a) the prototype's collection efficiency of $80 \%$ is about equal to that of the original roll-bond receiver prototype at a condition of zero thermal loss, and (b) the overall heat loss coefficient has been reduced from $0.65 \mathrm{Btu} / \mathrm{hr} \mathrm{\textrm {ft } ^ { 2 }}{ }^{\circ} \mathrm{F}$ for the roll-bond receiver prototype to $0.58 \mathrm{Btu} / \mathrm{hr}$ $\mathrm{ft}^{2} \mathrm{O}_{\mathrm{F}}$ for the serpentine receiver prototype (Ref 130). The back loss for both units was-determined to be $0.25 \mathrm{Btu} / \mathrm{ft}^{2} \mathrm{hr}{ }^{0} \mathrm{~F}$, and could be reduced to less than $0.1 \mathrm{Btu} / \mathrm{ft}^{2} \mathrm{hr}{ }^{\circ} \mathrm{F}$, by improved insulation. This improved performance further enhances the compatibility of the X3 CPC solar collector with both absorption cooling and solar Rankine cycle systems

- A prototype CPC solar collector having a concentration ratio of X10 is presently being fabricated at ANL. It is approximately 3 feet high from the focal region to the aperture and consists of a black cavity receiver and CPC reflectors made of "Kinglux" aluminum sheet fastened to wood ribs. A slit cylindrical cavity receiver has been incorporated into the design to reduce infrared reradiative losses while improving absorption of incoming radiation. Heat is extracted from the cavity receiver in a fluid circulated through several tubes 
brazed to the exterior of the cavity wall. The "Kinglux" aluminum sheet is expected to have a reflectivity of about $85 \%$ - an improvement of $10 \%$ over the "Alzak" sheet previously used. Cavity geometry is advantageous when the size of the internal surface area is large compared to the aperture area of the cavity.

- A prototype CPC collector identical in design to the above device except having a concentration ratio of $\mathrm{X} 5$ is concurrently being fabricated at ANL.

ANL is currently subcontracting the fabrication of prototype CPC collector modules having a concentration ratio between X5 and X6. Chamberlain Manufacturing Company of Waterloo, Iowa, and American Science and Engineering, Inc. of Cambridge, Massachusetts, have submitted designs to ANL for the fabrication of these prototypes.

The Chamberlain design, having extruded aluminum reflectors and receivers, appears too complex and costly for consideration as anything but a laboratory prototype for experimental use. However, Chamberlain has now designed a roll-formed collector that is more suitable for mass production. The AS\&E reflectors a re made from bending and rolling sheet metal then surfacing them with a good reflective aluminum sheet such as "Kinglux". The reflectors are snapped in place over the receiver sheet. AS\&E's design is suited for large quantity production but has some inherent heat transfer problems (i.e. a cooling fin effect caused by fixing. metal reflectors directly to the heat receiver) that should be studied further.

\section{3 ANL COLLECTOR TEST FACILITY}

ANL has constructed a sophisticated facility dedicated to testing solar collectors. The facility is installed in and on a mobile trailer and is fully instrumented to record rates of heat collection, ambient wind and temperature conditions, insolation, and collector thermal response. The instrumentation plan is to automate facilities for test data reduction with a minicomputer and using a printer for data logging. 
3. 4

THEORETICAL PERFORMANCE STUDIES

ANL has studied the theoretical heat transfer aspects of CPC solar collectors and has incorporated these studies into computer algorithms to predict the performance of these devices. Environmental Consulting Services, Inc. of Boulder, Colorado have also developed computer programs for ANL that serve to predict CPC performance. Reports of both studies were published in February 1975 by ANL as Report No. NSF/RANN/SE-AER-75-01065/PR/75/4, entitled, "Solar Energy Concentration." Data used in developing Figure 2-2 was produced from the ANL computer program (with the exception of the performance curve for the double-glass cover flat plate collector, Ref. 90). Laboratory tests of prototype CPC collectors have demonstrated a close correlation between computerized theoretical performance predictions and empirical performance.

$3-6$ 


\section{Sectiun 4 \\ CPC MASS PRODUCTIÓN}

\subsection{DESIGN}

The literature abounds with the idea that for small scale systems, the most significant single cost element in a solar thermal energy system is the solar collector. It is important, therefore, that collectors are designed to be durable, efficient and low cost. This last goal will assist in minimizing the total system cost. The goals of the ANL CPC solar collector develupment program should be directed toward satisfying these design considerations.

4.1.1 Durability of Materials Contributes to Product Reliability

A lifetime of 20 years has been estimated as a requirement for mass produced collector design (Ref. 48). For CPC flat panel collectors, componénts including the transparent cover, reflectors, receiver, insulation, frame, seals and adhesives should all be designed to meet the 20-year durability standard. Durability aspects of each of these items are discussed below:

- Transparent cover: The collector cover should be designed to withstand the destructive effects of wind pressure, hail, snow loads and thermal cycling and erosion. High transmissivity of the cover should also be maintained. In particular, the effects of UV radiation (which is detrimental to both transmittance and strength in certain materials) should be considered in choosing collector cover material and coatings.

- Reflectors: The compound parabolic reflectors should be designed to remain highly reflective and to maintain their parabolic shape throughout the prescribed collector lifetime using shapes that fully use the available strength of materials. Reflective coatings that deteriorate with age (i.e. some silvered surfaces) should be avoided. If the flow of the heat extraction fluid should fail, very high equilibrium temperatures will be reached at the heat receiver. Unless the reflectors can be adequately insulated from the receiver, they should be designed to withstand these very high temperatures. 
Reflectors should also'be designed to withstand extreme thermal cycling during normal collector operations.

- Receiver: The heat receiver should be designed to withstand thermal cycling, high no-flow equilibrium temperatures, corrosion, fouling, clogging, freeze-ups, and to maintain high solar absorptivity throughout the 20-year life goal. Aluminum receivers will be subject to galvanic corrosion in multimetal systems. The use of chromate inhibitors or sacrificial aluminum ion traps in the heat transfer fluid loop are potential solutions to the galvanic corrosion problem (Ref. 89). $\mathrm{Ph}$ control of boiler water in contact with aluminum is essential to avoid problems of this nature.

- Insulation: Many CPC collector designs considered to date require insulation to minimize heat losses through the back side. This insulation should be designed to maintain low conductivity and rigidity when subject to high no-flow equilibrium temperatures and thermal cycling inherent to normal operation. A potential problem arises when dealing with common metal receivers above $250^{\circ} \mathrm{F}$ in contact with most organic foam insulations. At these temperatures, the insulation material degrades and produces, among other by-products, hydrochloric acid and hydrofluoric acid. The use of foamed plastic insulation on common metal CPC receivers should, therefore, be avorded (Ref. 89).

- Frame, Seals and Adhesives : All seals, adhesives and frame components designed for incorporation into CPC collector assemblies should be selected to withstand the destructive effects of wind, precipitation, moisture, temperature, and the rmal cycling throughout the prescribed 20 -year lifetime. For applications to new residential and commercial construction, it is likely that the collectors will be integrated into the building design and will be required to function as "building skin" (i.e. planar components separating the buildings's inner space from the external space). As such, the collectors should be designed to perform the following functions reliably throughout their lifetime: 
- Support themselves against wind and gravity loads

- Thermally insulate the buildings' interior space from exterior space

- Resist the movement of wind, precipitation, and water vapor into the building and control the point of moisture condensation

- Control light and sound transmission

- Provide exterior surface aesthetics

To avoid leakage between the collector panels (which will tend to respond to insolation fluctuations with dynamic thermal expansions and contractions while installed on a relatively stable building structure), the following methods of inter-panel seals have been suggested (Ref. 48 ).

- sealant with backing strip.

- "zipper" gasket of hard neoprene

- gasketed metal cover strip

\subsubsection{Efficiency}

Optimal collection efficiency should be designed into CPC solar thermal collectors to compensate their relatively high cost. The collector efficiency is particularly sensitive to the design of the transparent cover, reflectors and receiver. Proper insulation to minimize back and side losses is also an important design criterion which has been discussed above in Section 4. 1.1 . Following is a discussion of cover, reflector and receiver design considerations that may be addressed in upcoming CPC development programs.

- Transparent Cover: To achieve maximum efficiency the collector cover should have high transmittance of incident solar radiation and low transmittance of infrared reradiation from the receiver. Common window glass and water-white glass have these transmittance characteristics and should be investigated on a cost-benefit basis in upcoming CPC studies. A low extinction coefficient to incident sola r radiation can be obtained in glass by keeping its iron oxide 
$\left(\mathrm{Fe}_{2} \mathrm{O}_{3}\right)$ content low. Certain plastics (e.g. Tedlar by Dupont) also. demonstrate the desired transmittance relationships and merit consideration because they are not subject to breakage to the degree of glass. With plastics, cost and deterioration rates should be investigated carefully.

Certain optical coatings may also be applied to collector covirs to enhance their performance and should be investigated for use with CPC collectors. Antireflection coatings have been demonstrated to halve reflective losses at glass plates. When applied to a solar collector cover, theoretical collection efficiency improves from $33.1 \%$ to $39.4 \%$ (Ref, 128). Transparent low emittance coatings have also demonstrated the potential for enhancing collector performance when applied to cover plates. A theoretical collector normally operating at $33.1 \%$ efficiency improves to $38 \%$ and $43 \%$ efficiency when transparent low emittance coatings are applied to the inside and outside cover surfaces, respectively (Ref. 128). (The $43 \%$ figure will be somewhat reduced in actual practice because of convective losses to the ambient air at the outer surface).

Dirt and dust accumulation on the cover surface does not appear to present a significant design problem. Tests have shown that occasional rains maintain cover transmittance within $4 \%$ of its unobstructed value (Ref. 48).

Reflectors: In particular, two characteristics of CPC reflectors are important to the design of an efficient solar collector: (a) that their surfaces be highly reflective; (b) that they do not serve as convective cooling fins to dissipate heat from the receiver.

Upcoming CPC studies should investigate reflective materials and coatings on a cost-benefit basis (keeping in mind prescribed life goals discussed earlier). High reflectance not only enhances solar concentration but also minimizes potentially detrimental heat absorption by the mirrors. Thin optical film coatings may also be investigated for use on CPC reflector surfaces to enhance 
concentration particularly for photovoltaic applications. Certain. photovoltaic cells (e.g. silicon cells) respond to radiation of ábout $0.9 \mu$ and above. Radiation below $0.9 \mu$ serves only to heat the cell and thereby degrades its performance without contributing to its electrical output. A "cold mirror" optical coating on the CPC reflectors would reflect about $81 \%$ of the useful radiation above $0.9_{\mu}$ while reflecting only about $21 \%$ of the detrimental radiation below $0.9 \mu$ (Ref. 128). Such coatings and the inherent consequences of mirror heating (caused by the $79 \%$ of radiation below $0.9 \mu$ that is absorbed by the mirror) should be investigated for application to CPC collectors.

The potentially detrimental convective cooling fin effect of the reflector bars may be reduced by careful collector design including:

- thermally insulating the heat receiver from the reflectors and

- fabricating the reflectors from material with low the rmal conductivity.

These criteria should be incorporated into CPC designs if convective heat dissipation from the reflectors is considered to be a problem. In the case of photovoltaic applications using "cold mirror" reflector coatings (as discussed earlier in this section) convective reflector cooling may be an advantage.

- . Receivers: Many receiver designs have been proposed for CPC applications, each with inherent advantages and disadvantages (Ref. 10, 47, 67, 130, 131). The concept of mounting a receiver plate with integral tubes vertically in the base of the CPC trough (See Figure 4-1) appears particularly attractive because the rmal losses from the back of the collector would be effectively eliminated(Ref. 67). Receivers should be designed to be high absorbers 


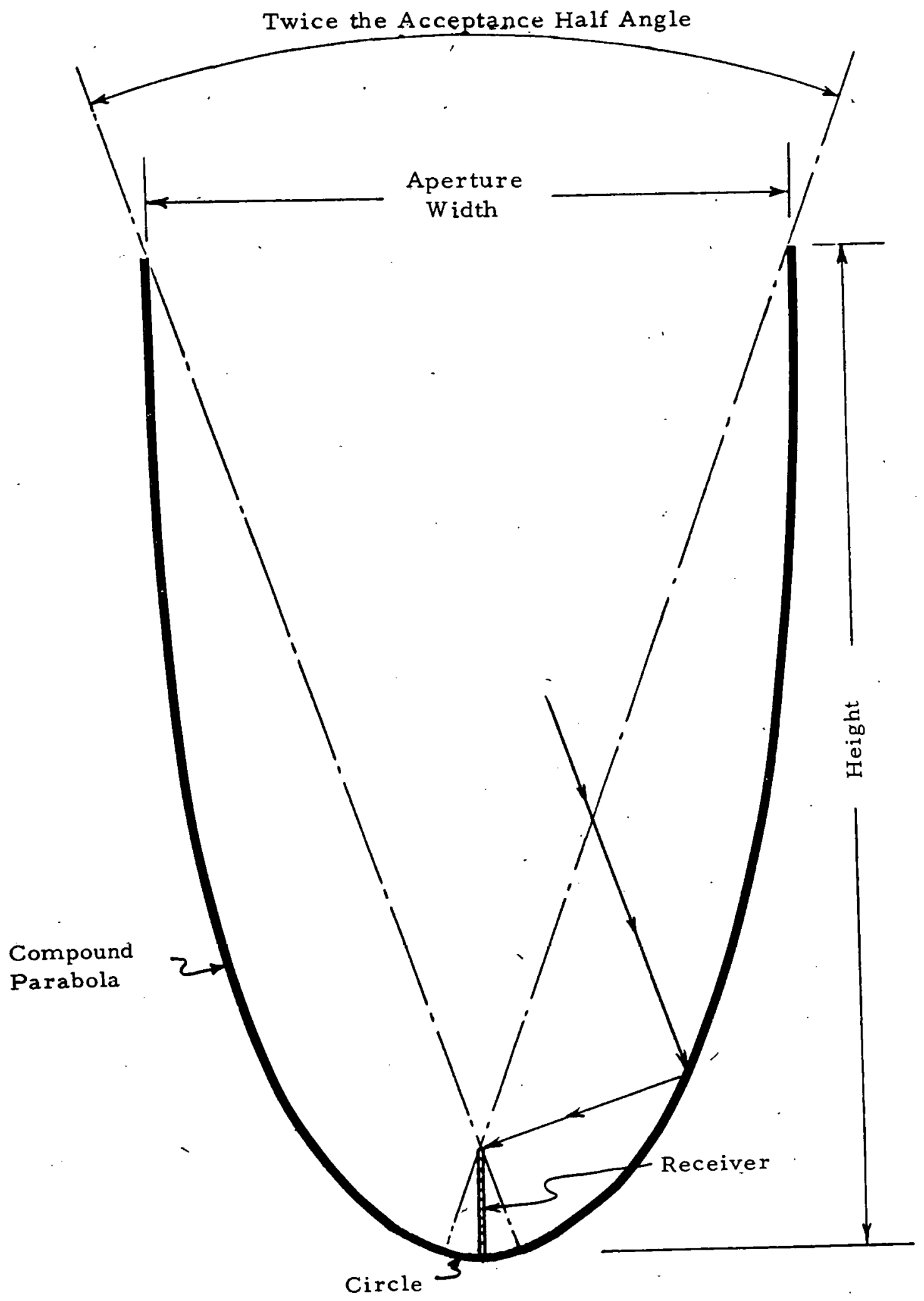

Figure 4-1. CPC Collector with Receiver Within Trough

4- 6 
of incoming radiation and low emitters of infrared radiation. Cavity designs and the use of selective black coatings may enhance receiver performance.

Using elongated dimensions, such as in long thin tubes, can reduce end losses. A length of up to 20 feet is the maximum practical. For the same reason, minimal cross-sectional areas should be used at the ends.

Selective black coatings are available today that absorb about $96 \%$ of incident solar radiation and emit about $6 \%$ of infrared (Ref. 128). All receiver coatings should be investigated for angular dependence of their propertie's when considered for CPC application, because of the many incidence angles in the concentrated radiation.

Evacuated transparent receivers (e.g. the Corning glass tube collector) will reduce convective loss at the receiver and may be coated with optical films (e.g. antireflection, low emittance, and selective absorber coatings) or used with black heat transfer fluids to improve collection efficiency. As discussed in Section 3.2, tests at ANL have indicated that serpentine receivers are advantageous to flat, integral tube plate receivers in that heat losses a re reduced. The above concepts represent potential designs for enhancing the performance of receivers to be integrated with CPC solar thermal collectors. CPC development studies should include directions for investigating such receiver designs.

The design of a receiver for $u$ se in CPC photovoltaic applications should be developed with the goal of resolving problems of concentrated radiation peaks on the cell surface and heat accumulation in the cell as discussed in Section 3.2. One potential solution to the problem of power loss due to radiation "shadows" caused by grid wires on the cell face lies in the current development of transparent conductive coatings (Ref. 128). 
Concurjent and interacting with the effort to design durable and efficient CPC solar collectors, must be a program to investigale their profitable, low cost mass production. The manufacturers of prototypes have strongly indicated that, to achieve significant cost reduction, CPC collectors should be highly automated. The final product should be structurally integrable panels with adequate strength, durability and fire-retardance to supplant major portions of structure in accordance with applicable building codes.

\subsubsection{Structural Integrability}

The CPC collector product should be manufactured in sizes that facilitate structural integrability. For high-volume use in new construction, it is recommended that modular dimensioning be adopted, with consideration being given to metrification. For low-volume use, and for retrofit, dimensioning may be based on manufacturing and handling considerations, assuming that special primary or intermediate support.will be provided. How ever, the concept of replacing "early generation" collectors with more refined units suggests early adoption of dimensions with long foreseeable utility.

It is anticipated that legislation generating metrification of the construction industry may be enacted in the foreseeable future. It may be assumed that there will be a metric equivalent of the present $4^{\prime} \times 8^{\prime}$ material sheet. The equivalent will probably be generated by the same process as the $4^{\prime} \times 8^{\prime}$ sheet, that is, a multiple of a standard spacing of light framing members. The basic concept of modular construction is that the modular dimension is between centerlines of joints.

Reduction of the number of attachment points increases the required stiffness of the panel, and the required strength of each attachment point. 
This increases factory effort while decreasing field effort. This is consistent with industry trends, and should permit an improved quality versus installed cost relationship.

It must be recognized that the frame to which panels are attached will be partially field-fabricated. Further, the shop fabrication must be assumed to be "custom", permitting a relatively low level of dimensional control, a condition expected in building construction. Attachment devices should therefore incorporate slotted holes, rotation, cam action, friction clamps, or a combination of these techniques.

\subsubsection{Fabrication Methods}

Five potential manufacturers of CPC solar collectors were contacted to investigate fabrication methods being considered. Following are brief summaries of these investigations:

- Environmental Consulting Services, Inc., Boulder, Colorado (Ref. 67) is considering two methods of fabricating large X2. 7 CPC collectors. One method involves screwing "Kinglux" aluminum reflector sheets onto a wood frame cut to the CPC shape and supported by aluminum tie bars. A 6" high roll-bond receiver is then to be slid into place vertically in the collector trough as shown in Fig. 4.1. One glass cover is used. Each concentrating trough is 50 inches high from base to aperture, 45 inches across at the aperture and 8 feet long. Because of the receiver placement within the trough, no insulation is required. The delivered, but not installed, cost of these collectors is reportedly $\$ 13 / \mathrm{ft}^{2}$ for 20 units, $\$ 7.50 / \mathrm{ft}^{2}$ for 1,000 units and $\$ 6.70 / \mathrm{ft}^{2}$ for 100,000 units. (See Append̀ix B for specific examples of commercial design.)

The second fabrication method involves all stamped and rolled sheet metal. The receiver design is also as shown in Fig. 4-1. The trough height is reduced to six inches and the aperture width reduced to six inches to maintain a X2.7 concentration. The length is 20 feet. Costs are estimated to be no more than $\$ 6.57 / \mathrm{ft}^{2}$ for $1,000,000$ square feet. The size of these CPC collectors creates a problem of structural integrability. 
- RAM Products, Sturgis, Michigan currently manufactures mirrored acrylic sheets that are snapped into a parabolic frame to form a solar concentrator. The mirror surface is second-surface vacuum deposited aluminum that is reportedly $4 \%$ more reflective than glass mirrors. The material is manufactured in $4^{\prime} \times 8^{\prime}$ sheets of $1 / 8^{\prime \prime}$ thickness (the most popular @ $\$ 2.39 / \mathrm{ft}^{2}$ ), 3/16', and 1/4'. The mirrored acrylic is salt, wind and hail resistant. One problem appears to be an operating temperature limit of $200^{\circ} \mathrm{F}$ above which the mirror degrades. If used with CPC collectors, the material would have to be well insulated thermally from the heat receiver (Ref. 78).

- Chambérlain Co. of Waterloo, Iowa is investigating the mass production of CPC collectors from roll-formed aluminum sheet. They anticipate using machines capable of forming 300 to 400 feet per minute of premirrored flat stock. The product may be a unitary trough with the top edge on one side turned under to facilitate fastening to an adjacent trough. A flattened pipe may be the receiver placed in the CPC focal region. CPC assemblies may be placed in a standard roll-formed aluminum frame having a cross-section 4 inches high and 2 inches wide (Ref. 124).

Talley Industries of Mesa, Arizona are interested in the CPC solar collector as a potential heat source for residential absorption air conditioning and power generation. They envisage producing CPC's from polished sheet aluminun of $20 \mathrm{ga}$. wall thicknès or less. Rather than a unitary trough, Talley plans to form aluminum sheets - into unitary back-to-back compound parabolas of adjacent troughs.

- Tinsley Laboratories of Berkeley, California is a producer of precision lenses and mirrors for industry. They discussed two potential CPC fabrication methods using polyurethane to form CPC cores. One method involves using a metal extrusion die with chilled walls to produce continuous lengths of the CPC trough from polyurethane foam. The chilled die walls give the exterior walls of the extrusion 
- a dense, hard and smooth surface. A problem here is instability of the material at high temperatures.

The second method involves molding the polyurethane foam under pressure to form CPC troughs. This method produces a much greater skin density than the extrusion method but is not as adaptable for high volume production. Instability at elevated temperatures remains a problem with this method as well.

The reflector surface on the polyurethane CPC cores would be $1 / 16 "$ single-strength mirrored glass that would be vacuum drawn onto the core and bonded with epoxy. The uniform vacuum load. - will prevent breakage of the glass during bending and any residual stresses may be removed by heat treatment while the vacuum is applied.

While resolving the convective heat loss problem of the previously discussed metal reflectors, the potential high cost of these methods and the instability of polyurethane at CPC operating temperatures are problems needing resolution (Ref. 114).

\subsection{COST AND PERFORMANCEE}

As shown in Figure 2-2, the CPC solar thermal energy collector is appreciably more efficient than a non-concentrating flat panel collector for applications requiring heat at temperatures above about $150^{\circ} \mathrm{F}(\mathrm{e} . \mathrm{g}$. solar absorption air conditioners and solar Rankine systems). This added efficiency permits CPC collector costs to be higher than the cost's of less efficient collectors while maintaining equivalent market capture potential.

\subsubsection{Non-Concentrating Collector Economics}

Several studies have been performed to project economic costs for nonconcentrating flat plate collectors (notably the NSF Phase Zero studies 
on "Solar Heating and Cooling of Buildings" by G.E. (Ref.48), Westinghouse (Ref. 125), and TRW (Ref. 116). According to G. E. study, the installed costs of mass produced non-concentrating collectors were estimated to be $\$ 5.80 / \mathrm{ft}^{2}$ for double-glazed panels and $\$ 4.70 / \mathrm{ft}^{2}$ for single-glazed panels $*$.

Based on the above collector costs, several candidate solar systems (including three of the systems described in Section 2.1 as potential CPC applications) were studied by G.E. to determine economic feasibility for ' nine geographic regions in the U.S. in 1980. Economic feasibility was ascertained if the life cycle cost ratio of the solar to conventional system was less than unity (i.e. the lifetime cost, including capital, operating and maintenance costs, of the solar system was less expensive than that of the most cost-effective conventional system serving identical functions).

Using the conventional fuel costs for 1980 shown in Fig. 4-2, G. E. calculated life cycle cost ratios for the solar Rankine heat pump (Fig. 2-4), lithium-bromide absorption cooling (Fig.2-6) and combined solar heating/absorption cooling (Fig. 2-7) systems - each having single or double glazed non-concentrating flat plate collectors. Figure 4-3 shows the geographic centers for which feasible life cycle ratios were determined for the given systems. Figure 4-3 indicates favorable relative eronomics for solar systems using non-concentrating flat plate collectors having single glazing (@ $\$ 4.70 / \mathrm{ft}^{2}$ ) or double glazing (@ \$5.80/ft ${ }^{2}$ ). In Section 4.3.2, a method is presented for determining the additional allowable installed cost of CPC solar collectors that may be used in these systems and maintain the same degree of economic feasibility.

\footnotetext{
* Panels are 4'x8', engineered for high production, 1 million panels to be produced annually, having plastic covers, selective black receiver plate and rigid foam insulation, 1974 dollar value.
} 


Oil $\frac{\text { Gas }}{2.76-3.51}$ Electricity

Boston

Charleston

Fort Worth

Los Angeles

Madison

Omaha

Phoenix

Washington
$2.13-3.10$

$2.76-3.51$

$1.99-2.84$

$.97-1.71$

$.78-1.57$

$1.58-2.12$

$1.40-1.84$

$.93-1.71$

$.78-1.57$

$1.65-2.60$

$2.69-3.31$
$9.43-9.63$

$6.98-7.46$

$8.80-11.32$

$6.19-8.17$

$8.49-11.66$

$7.33-10.35$

$8.80-11.32$

$10.33-14.89$

Figur̀e 4-2. Conventional Fuel Costs Used in General Electric Study (Ref. 48) 


\begin{tabular}{|c|c|c|c|c|c|c|}
\hline \multirow[t]{2}{*}{ - } & \multicolumn{2}{|c|}{$\begin{array}{c}\text { Solar } \\
\text { Heat Pump (Fig. 2-4) }\end{array}$} & \multicolumn{2}{|c|}{$\begin{array}{l}\text { Li Br Absorption } \\
\text { Cooling (Fig. } 2-6 \text { ) }\end{array}$} & \multicolumn{2}{|c|}{$\begin{array}{l}\text { Solar Heating w/ } \\
\text { Li Br Cooling (Fig. 2-7) }\end{array}$} \\
\hline & Economic & $\begin{array}{c}\text { Un- } \\
\text { economic }\end{array}$ & Economic & $\begin{array}{c}\text { Un- } \\
\text { economic }\end{array}$ & Economic & $\begin{array}{c}\text { Un- } \\
\text { economic } \\
\end{array}$ \\
\hline Residence & & & None & A11 & $\mathrm{OW}$ & $C, F W, L A, P$ \\
\hline $\begin{array}{l}\text { Multi-Family } \\
\text { Residence }\end{array}$ & & C, $\mathrm{FW}$ & $" 1$ & " & $\mathrm{MA}, \mathrm{O}, \mathrm{W}$ & \begin{tabular}{|l|l|l|l|}
$C, F W$, & $L A$ \\
\end{tabular} \\
\hline Office Bldg. & $\mathrm{F} \cdot \mathrm{W}$ & C] & $" 1$ & $" 1$ & $\begin{array}{l}\mathrm{LA}, \mathrm{MA} \text {, } \\
\mathrm{O}, \mathrm{W}\end{array}$ & C. FW, \\
\hline Industrial Bldg. & $P$ & & $" 1$ & $"$ & LA, MA, W & $\mathrm{C}, \mathrm{FW}, \mathrm{P}, \mathrm{P}$ \\
\hline Educational Bldg & & & $"$ & $"$ & $\begin{array}{c}\mathrm{FW} \text { LA } \mathrm{LA} \\
\mathrm{O}, \mathrm{P}, \mathrm{MA}\end{array}$ & \\
\hline Retail Store & & \begin{tabular}{|l|l|l|}
$C$, & $F W, P$ \\
\end{tabular} & 11 & " & $\begin{array}{l}\text { EW, MA, } \\
\text {, W }\end{array}$ & \begin{tabular}{|l|l|l|}
$C$, & $L A$, & $P$ \\
\end{tabular} \\
\hline
\end{tabular}

Key to Cities:
$B=$ Boston
MI = Miami
$\mathrm{C}=$ Charleston
O = Omaha
$\mathrm{FW}=$ Fort Worth
$P=$ Phoenix
LA $=$ Los Angeles $\mathrm{W}=$ Washington, $\mathrm{D} . \mathrm{C}$.
MA = Madison

$\square$ : Boxed Cities use single-glazed collectors@ $\$ 4.70 / \mathrm{SF}$; Others are double glazed@ $\$ 5.80 / \mathrm{SF}$

Figure 4-3. Geographic Centers Where Solar Systems Using Nonconcentrating Collectors Are or Are Not Economic in 1980 (Ref. 48) 


\subsubsection{CPC Collector Economics}

Following is a development (related to competing conventional costs)

of the allowable cost increment above non-concentrating flat plate collector cust goals that may be afforded by CFC collectors based on their improved efficiency.

Shown in Fig. 4-4 is a model of a system that collects, stores, transfers and converts solar energy into a form of energy that can be substituted for conventional fuels. From the model it is seen that the amount of delivered useful solar energy is given by:

$$
\mathrm{QE}=\mathrm{I} \times \mathrm{A} \times \eta \mathrm{c} \times \eta_{\mathrm{s}} \quad \mathrm{MMBtu} / \mathrm{YR}
$$

and its cost is:

$$
C E=\frac{\left[\left(C^{\prime} \times A\right)+C s\right] R+O M}{Q E} \quad \$ / M M B t u
$$

where $\mathrm{R}=$ annual capital cost amortization rate and $O M=$ annual system operating \& maintenance costs.

By substituting and rearranging terms the unit installed collector cost can be given as:

$$
C c^{\prime}=\frac{C E \times I \times \eta c \times \eta s}{R}-\frac{O M}{R \times A}-\frac{C s}{A}
$$

where CE now represents the competing cost of conventional fuels. By taking the derivative of the above collector cost relationship with respect to the collector efficiency, the following is obtained:

$$
\frac{d C c^{\prime}}{d \eta c}=\frac{C E \times I \times \eta_{s}}{R}
$$

This can be written in discrete form as:

$$
\Delta C_{c}^{\prime}=\frac{C E \times I \times \eta s}{R} \Delta \eta c
$$

which shows the allowable added collector cost that can be invested to produce an efficiency increase of $\Delta \eta \mathrm{c}$ and remain competitive with competing conventional fuels. 
SOLAR INSOLATION

$I\left(\mathrm{MMBtu} / \mathrm{yr} . \mathrm{ft}^{2}\right)$

官
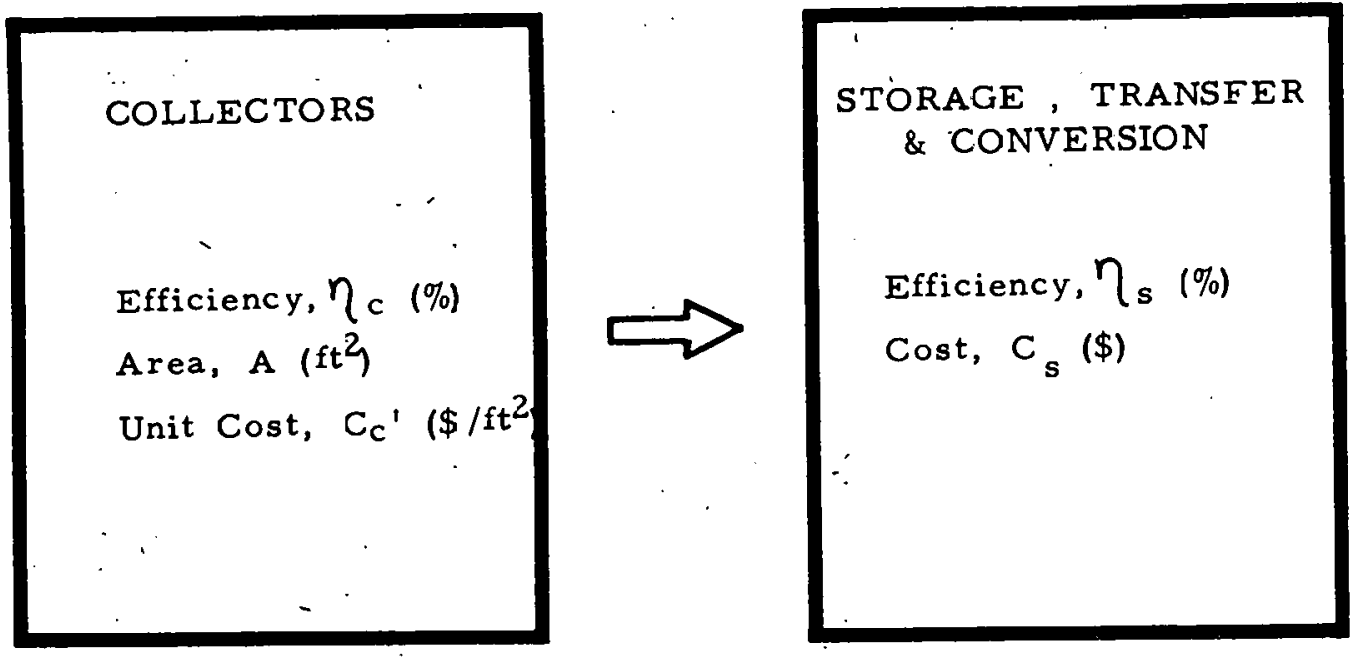

USEFUL ENERGY,

$\longrightarrow \mathrm{QE}_{\text {(MMBtu/YR) }}$

COST OF USEF'JL

ENERGY CE (\$/MMBtu)

Figure 4A. Solar Energy Conversion System Model 
Using the above equation, Fig. 4-5 was developed to illustrate the relation between allowable added costs of CPC collectors over cost projertions for non-concentrating flat plate collectors and competing conventional fuel costs.

The anticipated costs of competing conventional fuels and electricity are discussed in Section 6 of this report. The annual solar insolation, I, is assumed to be about $0.6 \mathrm{MMBtu}$ per year per square foot for average U.S. locations (Ref. 125). The annual amortization rate was calculated from the tollowing expression used to compute annuities of a principal subject to an interest rate, $i$ :

$$
R=\frac{i}{1-(1+i)^{-n}}
$$

Using an interest rate, i, of $9 \%$ (3) and the prescribed collector lifetime, $\mathrm{n}$, of twenty years (Ref. 48), the amortization rate, $\mathrm{R}$, is about $10.9 \%$. The storage, transfer and conversion subsystems efficiency, $\eta_{s}$, is taken as being $100 \%$ by assuming that heat losses from the storage tank and fluid transfer pumping power are negligible and that thermal energy is the useable energy form. Subsystem conversion efficiencies other than $100 \%$ can easily be factored into the values taken from Fig. $4-5$ if desired.

The allowable CPC cost increments derived from Fig. 4-5 represent installed costs which include not only the added manufacturing costs but also:

- manufacturers' ${ }^{\prime}$ gross margin of $30-32 \%$

- distributors' gross margin of 17-20\%, and

- dealers' gross margin of 29-33\% (Ref.48).

This accounts for installation of the collectors by the dealer but not the integration of the collectors into the building structure which would be the builders' responsibility. To estimate the manufacturing cost increments alone, the installed cost increments in Fig. 4-5 should be divided by about 2.1 to account for the above gross margins. 


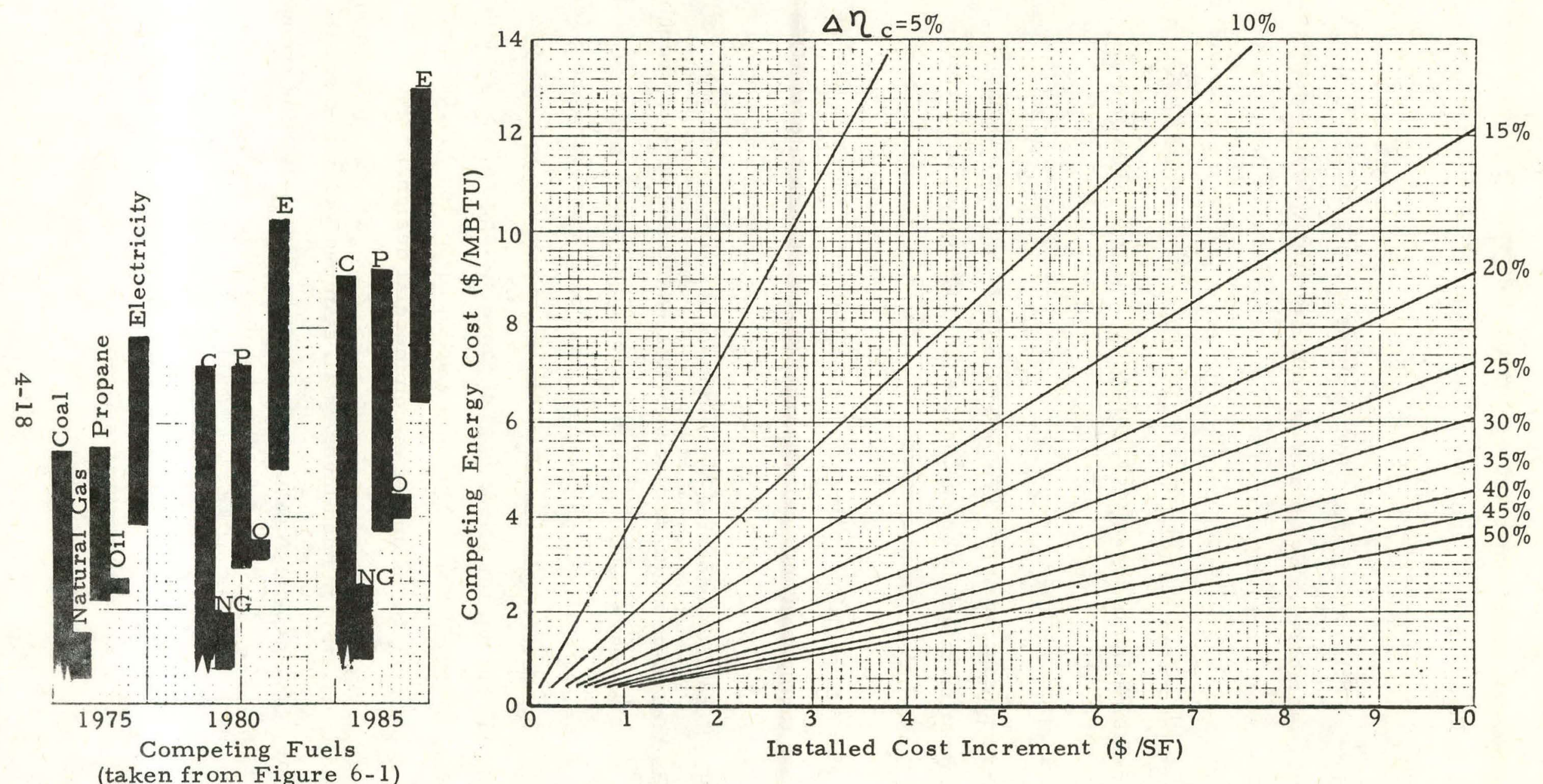

Figure 4-5. Ircremental Cost Versus Efficiency for CPC Solar Collectors 


\subsubsection{CPC Cost Goals}

To appropriately utilize the CPC cost allowance data in Fig. 4-5, a study is required of the effective efficiency increase of CPC collectors compared to non-concentrating collectors over a full year's operation. In the absence of such data, a rough cut of CPC cost goals may be made by using instantaneous efficiency data such as is illustrated in Fig. 2-2. For example, the residential solar heating/solar lithium bromide absorption cooling system requires collector absorber temperature of about $200^{\circ} \mathrm{F}$. 'At this temperature," the CPC collector is about $27 \%$ more efficient than a double glass collector at the instantaneous conditions specified in Fig. 2-2. Referring to Fig. 4-5 and assuming that natural gas is the competing fuel source in 1980 at a representative value of $\$ 1.70 / \mathrm{MMBtu}^{*}$, the projected allowable installed cost of CPC collectors will be about $\$ 2.50 / \mathrm{ft}^{2}$ above the cost of a double glass non-concentrating collector.

According to the G. E. Study results (Ref. 48) shown in Fig.4-3, at $\$ 5.80 / \mathrm{ft}^{2}$ double-glass non-concentrating collectors used with a residential solar heating/solar lithium-bromide absorption cooling system will be economically viable in 1980 in Omaha and Washington regions. Therefore, a

$\therefore$ CPC collector having an installed cost of $(\$ 5.80+2.50=) \$ 8.30 / \mathrm{ft}^{2}$ should also be economically viable for this system in 1980 in these regions. Accounting for the manufacturer's, distributor's and dealer's gross margins discussed in Section 4.3.2, the manufacturing cost goal of CPC collectors for this application would be of the order of $\$ 3.95 / \mathrm{ft}^{2}$.

*Given in Reference 48 
Manufacturing costs decrease with mass production until a certain high volume of production is attained. This minimal cost level can be used as a production target in setting design cost goals. The point where economies in large-scale production no longer drive down costs for three types of collectors has been estimated, as follows:

Flat piate collector '(X1 concentration) module $\quad$ - 60,000 units (Ref. 123) CPC single trough (X2.7 concentration) 4'x4'x8' - 100,000 units (Ref. 67) Corning evacuated solar collector (Xl concentration) tube - 150,000 units(Ref. 123)

Competing devices, such as the Corning Glass tubular evacuated solar collector, undoubtedly will be designed to achieve similar cost goals. It is unlikely that a competing device would be produced in large quantity until 1980 because of production line inertia. Therefore any significant reduction in costs attributed to mass production is unlikely before the period 1980 to 1985 . It a ppears doubtful that a proven device capable of delivering solar heat reliably at $300^{\circ} \mathrm{F}$, can be installed commercially for less than $\$ 10 / \mathrm{ft}^{2}$ in the near future. (Office of Technology Assessment has estimated this 1975 cost (less profits) and projected a cost of $\$ 9 / \mathrm{ft}^{2}$ in 1985). 
Section 5

\section{A COMPARISON OF SOLAR COLLECTORS}

\subsection{INTRODUCTION}

To determine appropriate $R \& D$ goals for the compound parabolic concentrator (CPC), its performance, among many other factors, must be evaluated and compared to that of other solar collectors. Such a performance comparison together with cost information would help in assessing the competitiveness of the CPC for various solar energy applications.

In general, the evaluation of collector optical and thermal performance involves a number of design parameters. These include the flow rate of the collector coolant, the absorbance and emittance of the receiver surface, the transmittance of cover sheets, the number of cover sheets, the reflectance of mirrored surfaces, concentration ratio, acceptance angle, tracking versus nontracking, etc. These parameters, when assigned values for a given collector design, determine collector performance. In addition to design parameters, environmental parameters such as insolation, wind, dust, etc. also affect performance.

Collector thermal and optical performance can be measured by a number of parameters. These include the quantity of energy collected, the heat losses, net heat output, receiver temperature, and the temperature difference between the receiver and ambient air $(\Delta T)$. These parameters are not all independent of each other. For example, collector heat losses are directly related to $\Delta \dot{T}$.

In general, receiver temperature, a measure of the "quality" of the heat collected, should be considered. 
Another parameter, collector efficiency (the ratio of heat output to the total amount of radiant energy falling on the collector), accounts for the quantity of energy collected, heat losses, and heat output. Consequently, collector efficiecy and receiver temperature are used as the primary measures of collector performance in the comparison.

Three additional performance parameters are useful in comparing the CPC to other solar thermal collectors. These are optical efficiency (theorétical maximum percentage of collected global radiation that is conveyed to an absorbing surface where the energy is converted into thermal energy), concentration ratio, and acceptance angle. Since, for a flat plate collector the collecting surface is also the abosrbing surface, the optical efficiency is $100 \%$; for a concentrating collector, only the di-rect portion of the global radiation is concentrated onto the absorbing surface and the optical efficiency is less than $100 \%$. The acceptance angle is defined as the maximum angle from the normal direction at which radiation is accepted.

The objective of this section is to present the results of a first order performance romparison. Since the number and variety of solar collectors are so extensive, it is necessary to group them into three basic design categories: the flat plate collector, the concentrating collector, and the CPC. The comparison focuses on the performance characteristics that are inherent in the design approach of each collector category. The flat plate collector is treated as a generic class. Because of limited performance data on concentrating collectors, the Honeywell parabolic trough collector is taken as a representative concentrating collector. The comparison is summarized in table form in Section 5. 5, where collector efficiency, receiver temperature, optical efficiency, concentration ratio, and acceptance angle are the five performance parameters that are compared. 


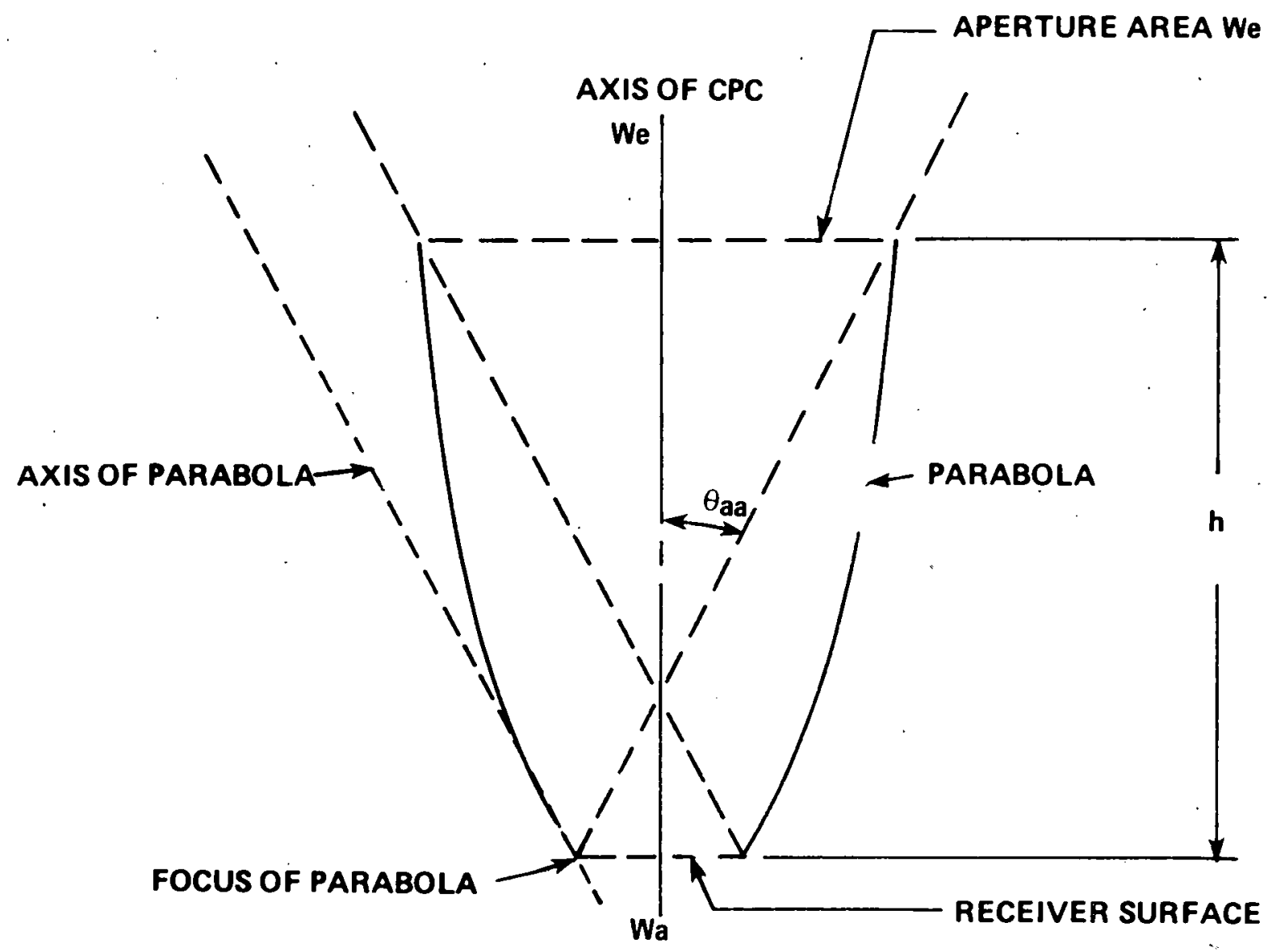

Figure 5-1. Cross Section of the Basic Optical Element of the CPC (Ref. 10) 
The basic optical element of the CPC consists of two sections of a parabola as shown in Figure 5-1 (Ref.10). The axis of each parabola is oriented $\theta$ aa degrees on each side of the collector's centerline, where $\theta$ aa is the acceptance half angle. This cross-sectional shape permits all direct radiation entering at angles less than $\theta$ aa from the normal direction to be concentrated on the bottom absorbing surface, either by direct impingement on the surface or by reflection from the parabolic sides. In addition, any diffuse radiation that impinges directly on surface is also collected.

The acceptance half angle, $\theta$ aa, depends on the ratio of the aperture area to the absorber area and can be expressed by the relationship $\theta a a=\sin ^{-1}\left(\frac{W a}{W e}\right)$, where $W e$ is the aperture area and $W a$ is the receiver area. The depth of the collector $h$ depends on the ratio $\frac{W a}{W e}$. To reduce the cost, the'depth can be truncated from what the concentration ratio would dictate without seriously affecting collector performance. This truncation reduces the number of reflections of noimally incident light and results in an average number of reflections that is typically:less than one.

Many variations of the basic CPC design are possible. The most common variation results from the trading of angular acceptance for. concentration. Concentration ratios greater than $\mathrm{X} 10$ are usually not considered because of the small acceptance angles.

Several variations in receiver design have been considered to reduce infrared reradiation and to optimize the heat transfer from the receiver to the coolant. Also, it has been proposed that photovoltaic cells be used for the radiation absorbing surface (receiver) of the CPC. One of the difficulties encountered has been the non-uniform distribution of solar flux 
on the cell surface, resulting in poor performance. Different urientations of the cell in the absorbing area and radiation scattering lechniques have been considered as improvements for this application.

A transparent cover sheet of high transmittance can be put over the a perture to minimize reradiation out of the collector. For the receiving. surface, both selective and non-selective coatings have been considered.

Since the CPC can collect radiation at all angles up to the acceptance angle, daily tracking of the sun is not necessary, although a seasonal adjustment of its orientation may be desirable. To facilitate such seasonal adjustment, the reflecting surfaces of the CPC can be moved to accommodate the seasonal angle of the sun, as shown.in Figure 5-2 (Ref.131).

Winston has proposed a cylindrical mirror for concentrating radiation onto a tube of a flexible design (Ref.133). The cross-section of the tube may, for example, be circular, oval, rectangular, or even fin-like. The concentration achieved is $\frac{d}{S}=(1 / \sin \theta a a)$, where $S$ is the circum ference of the tube and $d$ is the width of the collector aperture. This design may have advantages for certain types of receivers, both solar -thermal and photovoltaic.

In addition to the CPC design variations already discussed, several "hybrid" collectors that utilize CPC's have been proposed to enhance the concentration ratio (Ref.131). Figure 5-3 illustrates three such hybrids that use a CPC as a second stage concentrator. The first design combines a CPC with a tracking parabolic trough collector. The second design uses a stationary CPC-receiver second stage, but employs motor driven Fresnel-type mirrors to track the sun. The 


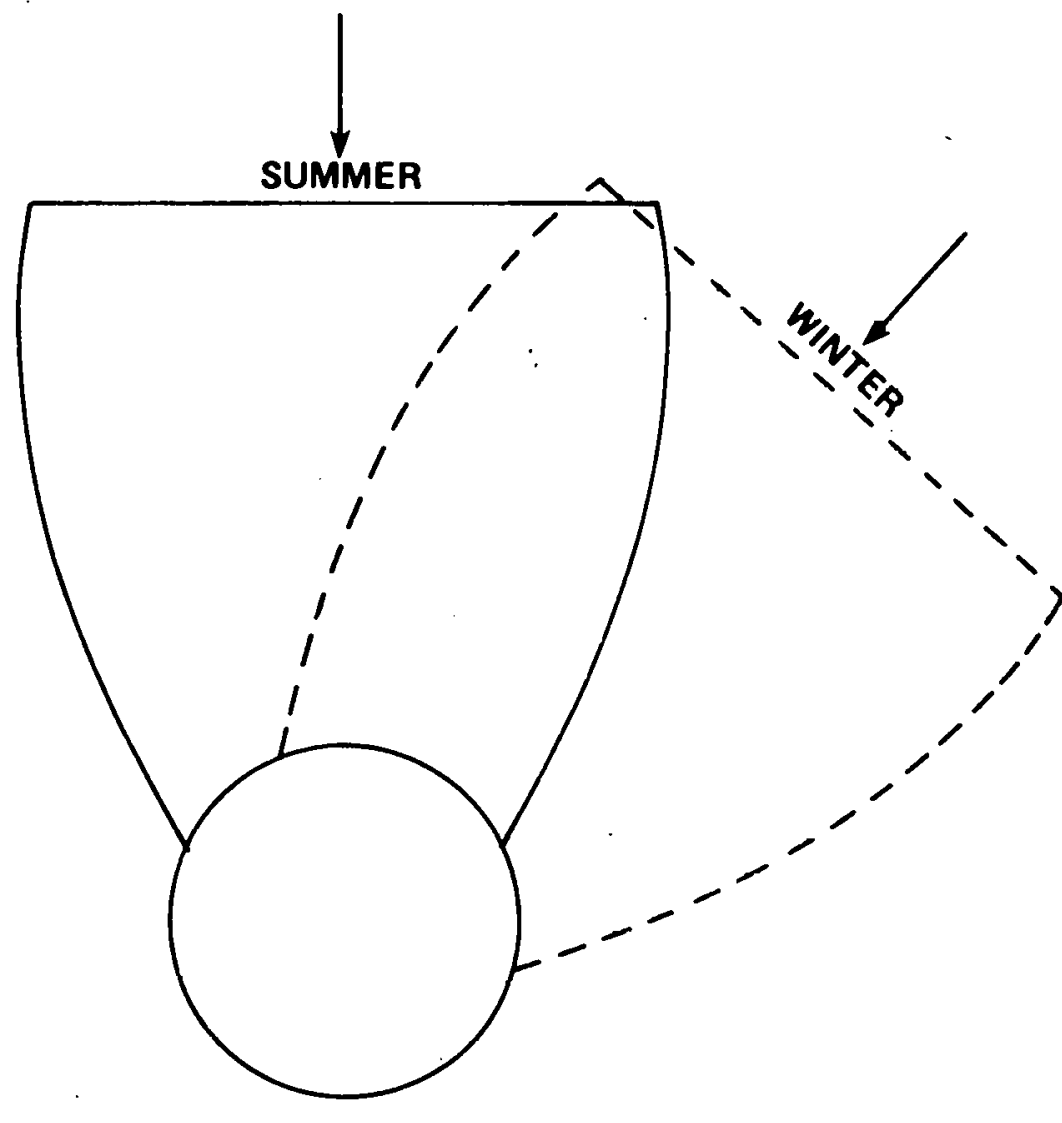

Figure 5-2. Seasonal Collector Orientations (Ref 131) 

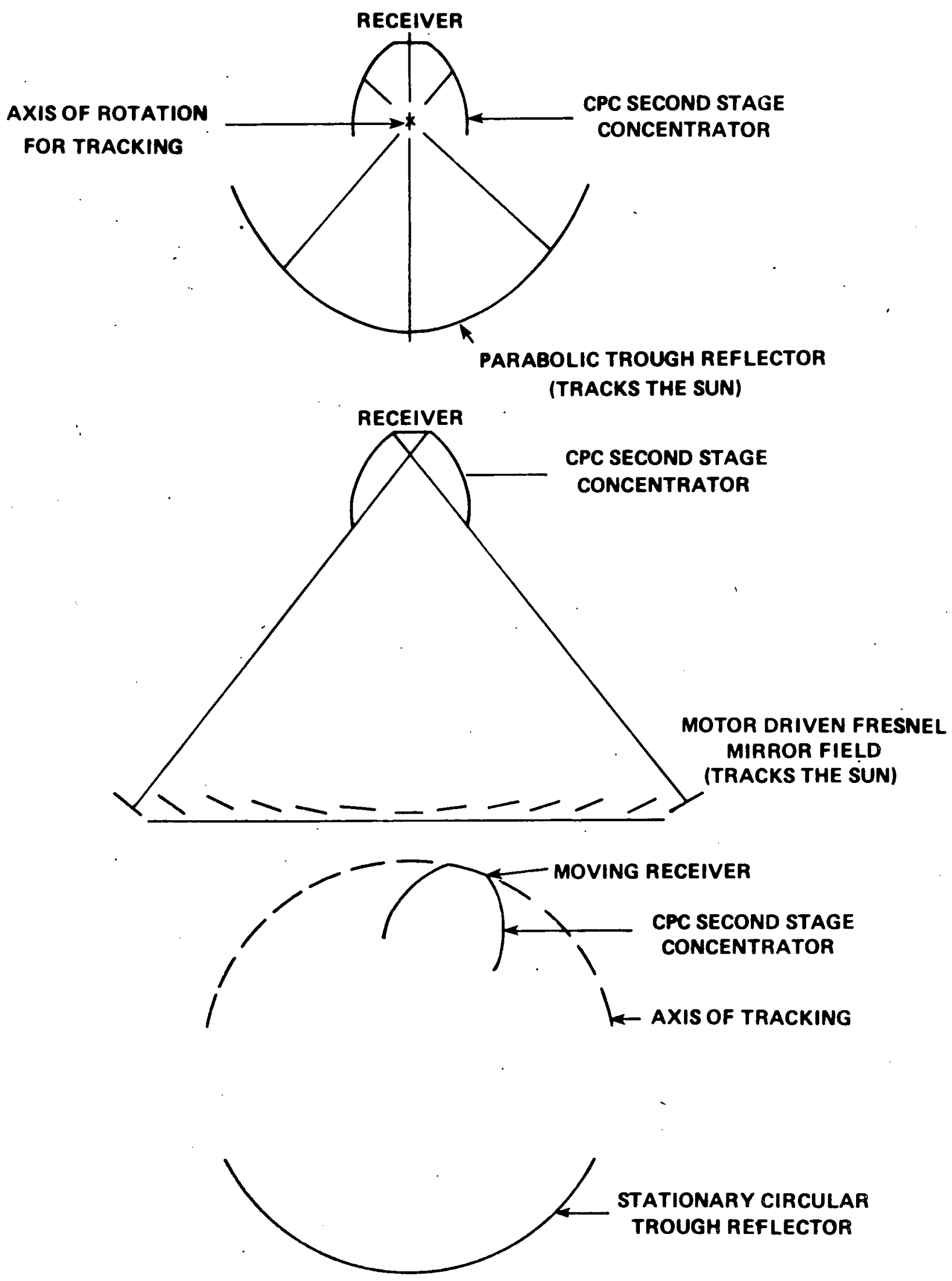

Figure 5-3. Three Hybrid Collectors Using the CPC as a Secondary Stage (Ref. 131) 
third hybrid collector consists of a stationary circular trough collector and a moving CPC-receiver that is capable of moving along a path that is an extension of the primary collector circle. In the last two hybrids the purpose of the CPC secondary is reportedly to increase concentration from $\mathrm{X} 30$ to $\mathrm{X} 60$.

To evaluate the performance of the CPC and compare it to that of th? flat plate collector, Argonne National Laburatury (ANL) has calculated total theoretical heat losses from a flat plate collector and from CPC's of concentrations X3, X5, and X10, assuming the same absorbing surface for all four. Results are presented in Table 5-1 (Ref. 10). It can be seen from this table that the CPC's suffer less heat losses than the flat plate. The flat plate in this case is a degenerate case of a CPC with a concentration ratio of $\mathrm{Xl}$.

It is also.evident from the table, the heat loss diminishes as concentration ratio is increased for all three receiver temperatures considered. Figure 5-4 shows the relationship between collector efficiency and $\Delta \mathrm{T}$ (receiver temperature minus air temperature) for the four collectors, as again calculated by ANL (Ref. 10, fig. 7, pp 3-37). It can be seen that efficiency improves with concentration ratio at higher temperatures.

Environmental Consulting. Services, Inc. has calculated theoretical CPC performance as a function of hours from solar noon (Ref. 44, fig. 8, p. 27). Figure 5-5 shows the change in absorber temperature, collector efficiency and the useful energy delivered by the collector during a period of 5 hours from solar noon. 
TABLE 5-1

TOTAL HEAT LOSSES IN Btu/ft $/ \mathrm{fr}^{-2}$ FOR FLAT PLATE AND

CPC AS FUNCTION OF CONCẸTRATION AND ABSORBER TEMPERATURE

\begin{tabular}{|c|c|c|c|c|}
\hline \multirow{2}{*}{$\begin{array}{c}\text { Absorber } \\
\text { Temperature }\end{array}$} & Flat Plate & $\begin{array}{c}\text { CPC } \\
\text { X3 }\end{array}$ & $\begin{array}{c}\text { CPC } \\
\text { X5 }\end{array}$ & $\begin{array}{c}\text { CPC } \\
\text { X10 }\end{array}$ \\
\cline { 2 - 5 } & 199.0 & 97.8 & 70.0 & 44.8 \\
\hline $300^{\circ} \mathrm{F}$ & 394.7 & 191.3 & 135.3 & 83.2 \\
\hline $400^{\circ} \mathrm{F}$ & 655.8 & 314.1 & 219.5 & 131.2 \\
\hline
\end{tabular}

(Transparent front cover temperatures for these conditions range from $52^{\circ} \mathrm{F}$ to as high as $186^{\circ} \mathrm{F}$, as a function of the forward heat losses.) 


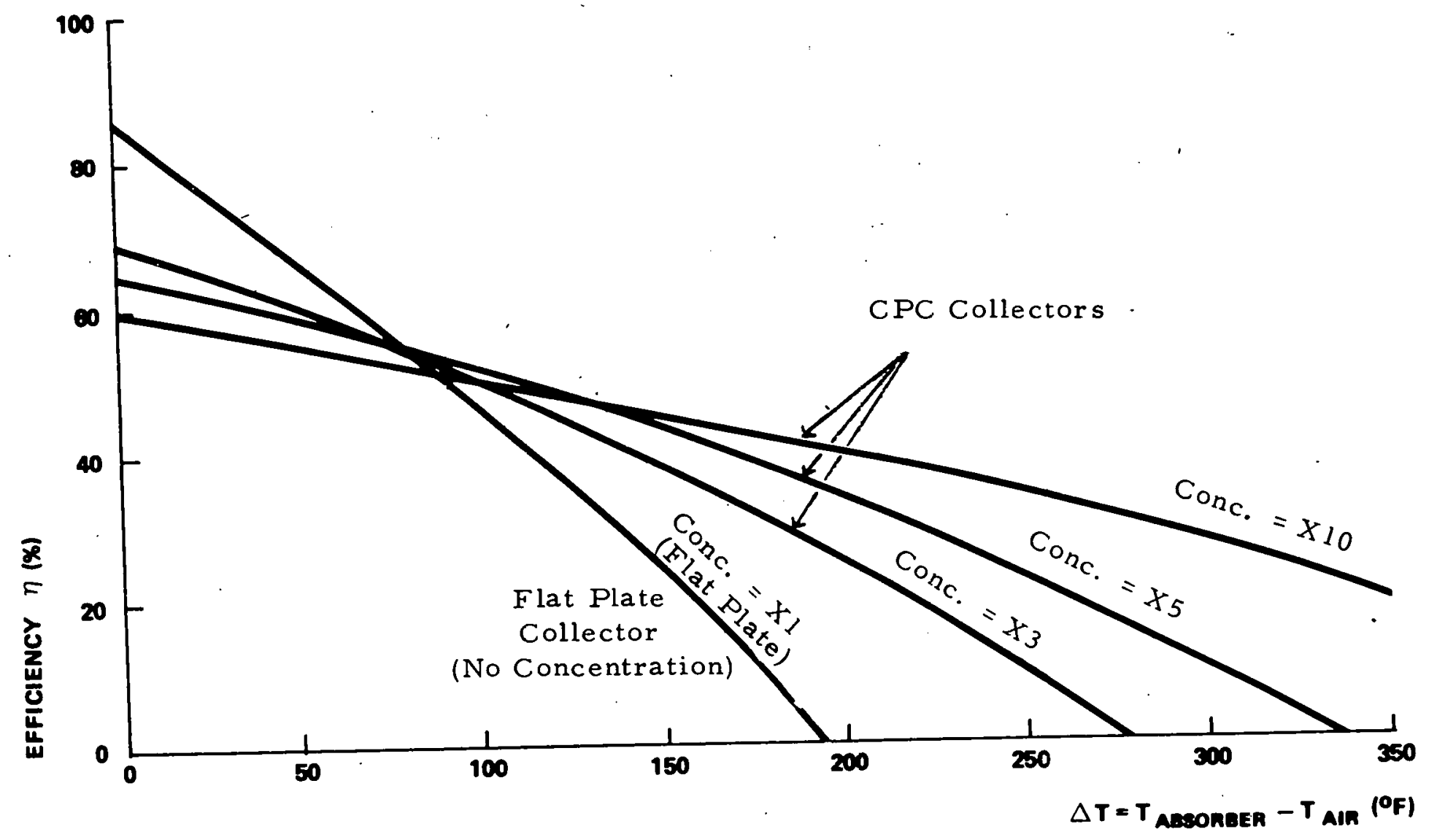

Collection Efficiency $\boldsymbol{\eta}$ of CPC Solar Collector

As Function of $\Delta \mathrm{T}=\mathrm{T}_{\text {absorber }}-\mathrm{T}_{\text {air }}$ for Concentration Equal to $\mathrm{X} 1$

(Ordinary Single Cover Flat Plate Collector), X3, X5 and X10. (Ref.10)

Figure 5-4. Solar Collector Efficiency 


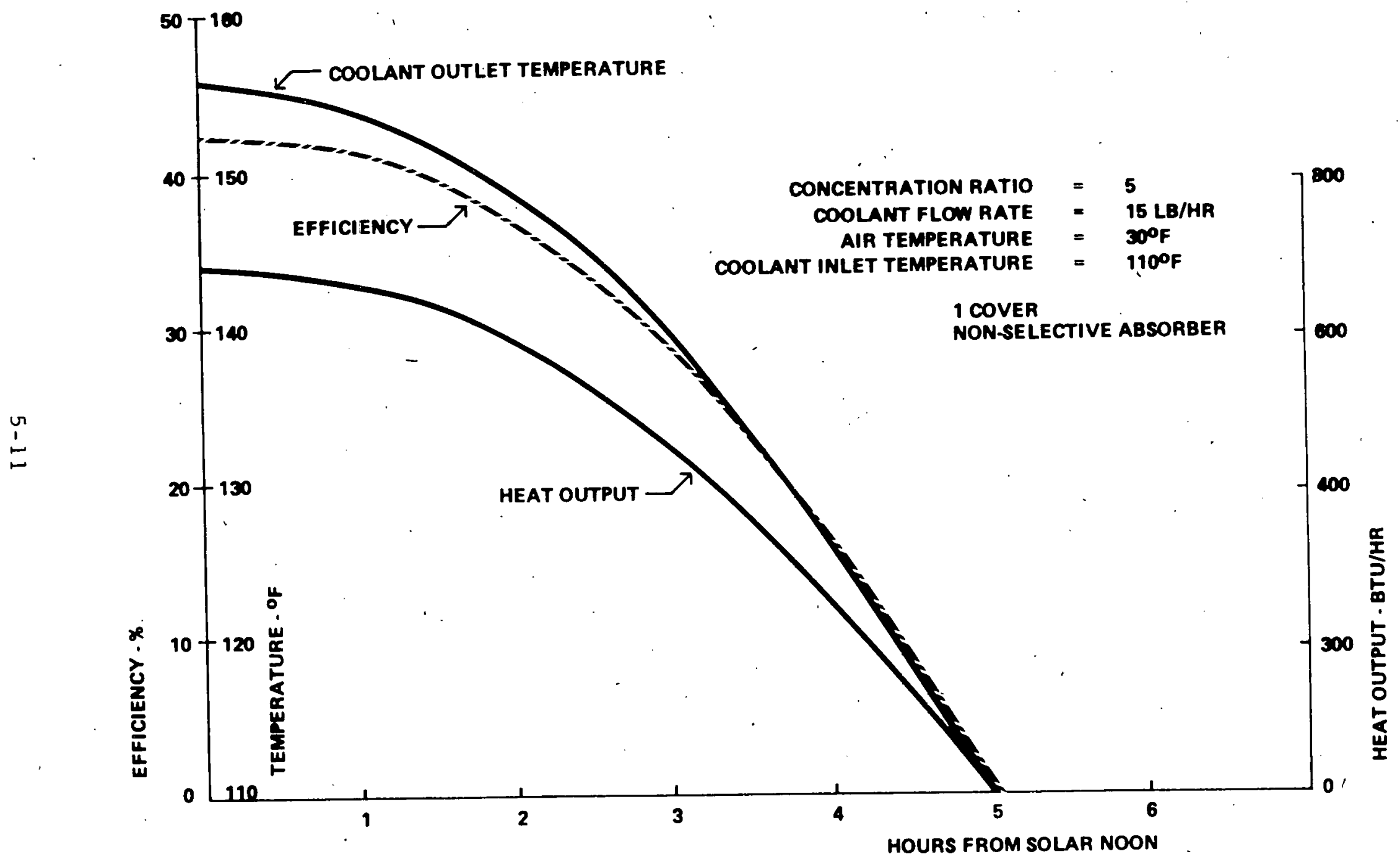

Figure 5-5. Computed Hourly Performance for a CPC (Ref. 44) 
TABLE 5-2

OPTICAL EFFICIENCIES OF THREE CPC DESIGNS (X3, X5, X10) AS A FUNCTION OF PERCENTAGE OF GLOBAL RADIATION THAT IS DIFFUSE

CPC Conc. Ratio

$\times 3$

X5

X10

\begin{tabular}{lllll} 
\% Diffuse Radiation \\
\hline 10 & $\underline{20}$ & $\underline{50}$ & $\underline{70}$ & $\underline{100}$
\end{tabular}

93.3

86.6

66.7

53.3

33.3

92

84

60

44

20

91

82

55

37

10 
For a given intensity of total diffuse radiation, $I_{d}^{O}$, the diffuse light absorbed by the CPC, $I_{d}^{\prime}$ decreases as the concentration ratio $X$ increases, as expressed by the relationship (Ref. 1):

$$
I_{d}^{\prime}=\frac{I_{d}^{O}}{X} \quad(\text { Ref. 131) }
$$

Table 5-2 shows how optical efficiency varies with concentration ratio of the CPC collector for that part of the global (direct and diffuse components) radiation that is diffuse.

It can be seen from this table that an increase in the amount of diffuse radiation that can be collected by a CPC is gained at the expense of concentrating capability.-

A flat plate solar heat collector comprises a radiation-absorbing flat plate beneath a transparent cover usually with the underside of the absorbing plate being insulated to reduce downward heat losses. Provision is made to circulate air or water (or other fluid) through the system to remove the absorbed heat.

The design of flat plate collectors can be varied in a number of ways, as illustrated in Figure 5-6 (Ref.7, fig. 10, pp 59.12).

Heat losses from flat plate collectors are conductive, convective, and radiative losses. The loss from the absorbing surface upward to the bottom glass plate is by radiation from the absorbing surface and by convection in the air gap between the plate and the bottom of the glass cover. Conduction losses occur through the various components of the collector, mostly through the casing and coolant piping. 


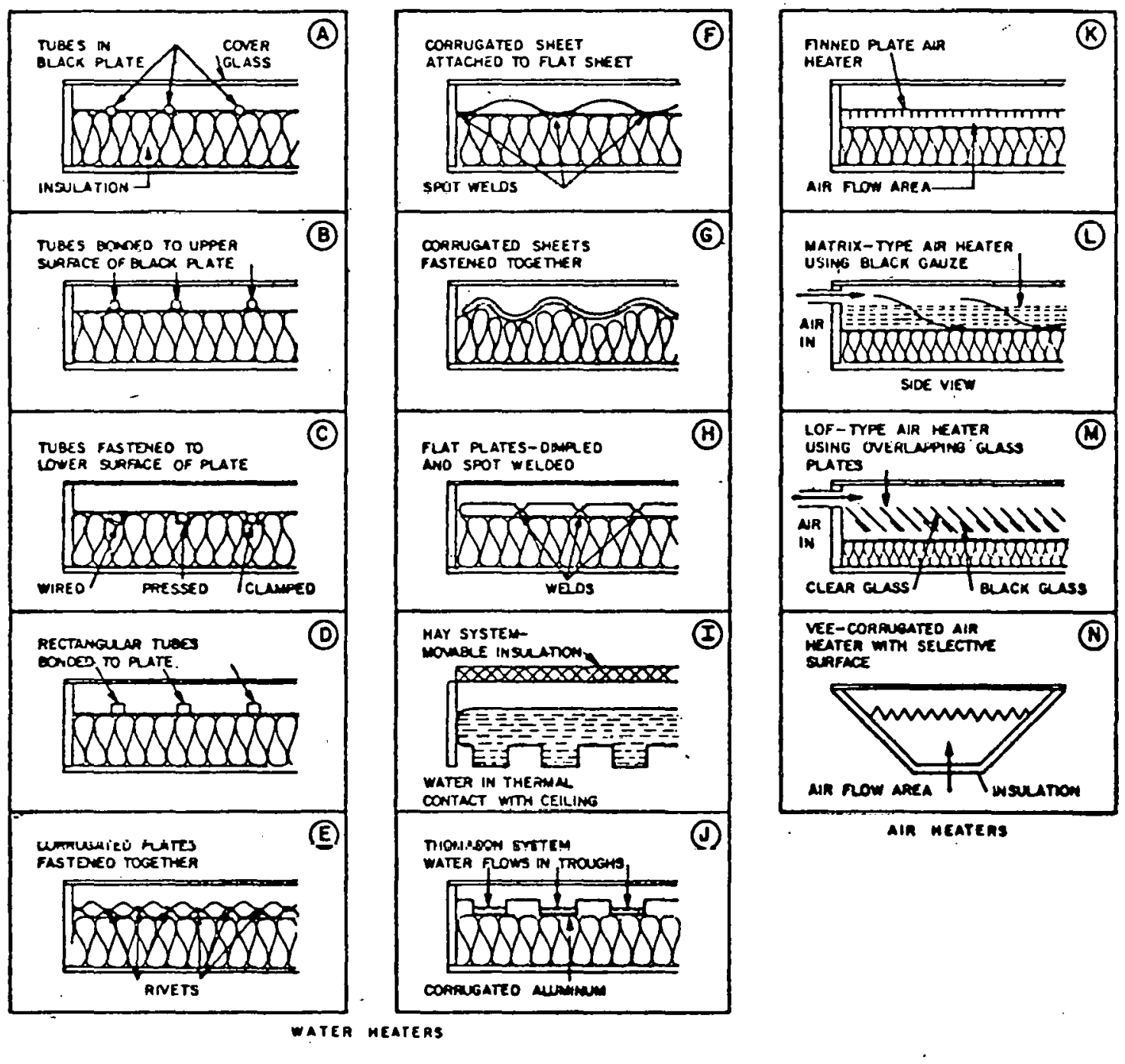

Figure 5-6. Variations of Flat Plate Collector Design (Ref.7) 
A heat balance, expressed in terms of unit area of flat plate collector surface may be stated as:

$\begin{aligned} & \text { incident } \\ & \text { insolation }\end{aligned}$
$\begin{aligned} & \text { gain } \\ & +\begin{array}{l}\text { heat loss upward } \\ \text { from collector }\end{array}\end{aligned}$

The loss due to reflection from the cover glass or glasses is approximately $4 \%$ of the energy passing through each air-glass interface, for incident angles up to 35 degrees. Thus, $8 \%$ is lost for a collector having a single cover sheet; $15 \%$ is lost for 2 sheets; and $22 \%$ is lost for 3 sheets.

There is a marked reduction in collection efficiency with increasing temperature difference between the collector inlet temperature $T_{\text {in }}$ and the ambient air $\mathrm{T}_{\mathrm{amb}}$. Efficiency at relatively high temperature differ ential is enhanced by the use of two cover glasses when the absorber has a non-selective surface. When a good selective surface is used, collection efficiency is improved still further, and a single cover glass is adequate. Figure 5-7 (Ref. 100, fig. 6) shows the variation of collector efficiency as a function of the collector parameter $\left(\mathrm{T}_{\text {in }}-\mathrm{T}_{\mathrm{amb}} / \mathrm{q}_{\text {ins }}\right.$, where $q_{i n s}=$ solar insolation rate in $B t u / h r-f t^{2}$ ) for different combinations of glass covers and absorber coatings.

The use of a solar transparent honeycomb material is experimentally shown to provide greater collection efficiency for both flat black and selective black coatings in the vicinity of $200^{\circ} \mathrm{F}$ (Ref.36) For low temperature application, the performance advantages of honeycomb material over those of other coverings are not substantial. 


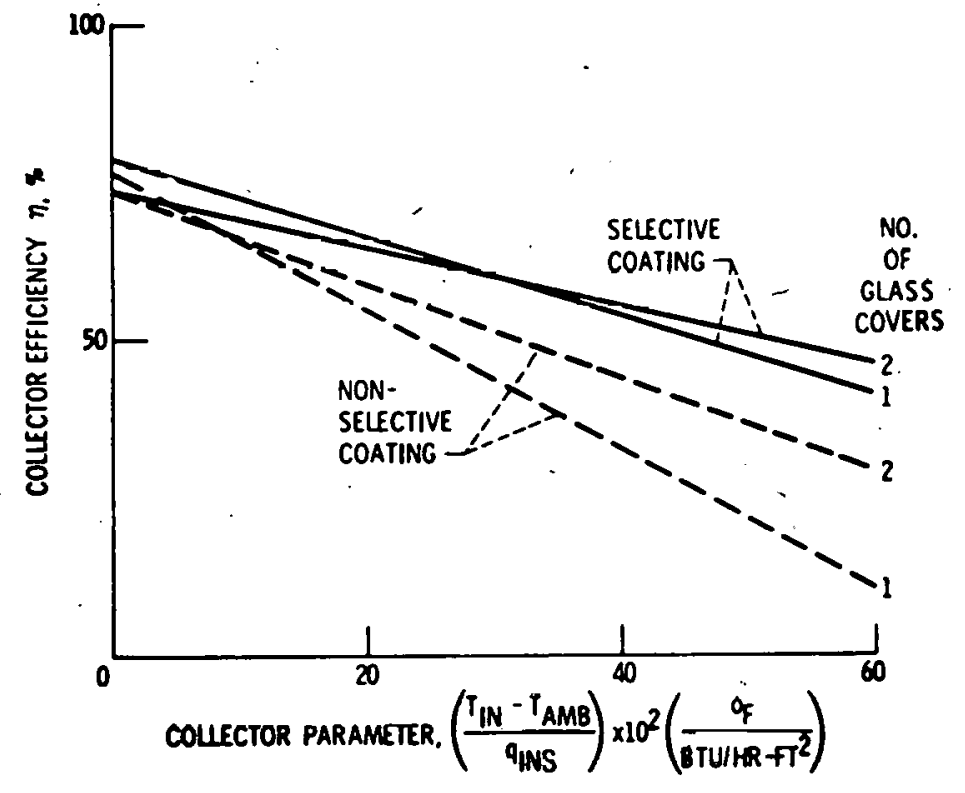

Figure 5-7. Theoretical Flat Plate Collector Efficiencies (Ref. 36) 
An important variable in the design of flat plate collectors is the air gap dimension between the absorbing plate and a transparent cover sheet and the air gap between the first and second cover sheets (if two cover sheets are used).

As a variation of the flat plate collector, Corning Glass Works has developed a tubular solar collector (Ref. 34) incorporating a selectivelycoated flat absorber plate housed within a highly-evacuated glass tube.

The tubes are arranged side-by-side and mounted in manifold racks at each end. The tubes are fabricated with high purity, high strength durable glass having an overall transmittance of $92 \%$. Because only one layer of glass (1/10 in. thick) is required, reflective and absorptive losses are minimized. Furthermore, due to the high vacuum inside the tube, convection and conduction losses are also greatly reduced. In addition, the selective absorber coating reduces reradiation losses. Corning claims that tracking is unnecessary to achieve working temperatures as high as $300^{\circ} \mathrm{F}$ with good efficiency (Ref. 34). This collector is reported to operate with its glass envelope at temperatures approaching ambient, i.e. almost tepid to the touch.

The efficiency of a horizontal, flat plate collector has a maximum value at solar nison that varies depending upon the number of cover glasses, selective or flat black absorber coating, other design parameters, and environmental conditions. For example, figure 5-8 (Ref. 68,-fig. 4, p. 5 . shows the change in collector efficiency during the day for both selective and non-selective absorber surfaces as reported by the University of Pennsylvania for a test conducted on January 9, 1973. For these conditions the maximum efficiency is $70 \%$. On the other hand, Figure 5-9 (Ref. 104, fig. 4, p. 40) shows a corresponding theoretical efficiency as calculated by Honeywell, Inc. under a different set of conditions to be only $55 \%$. 


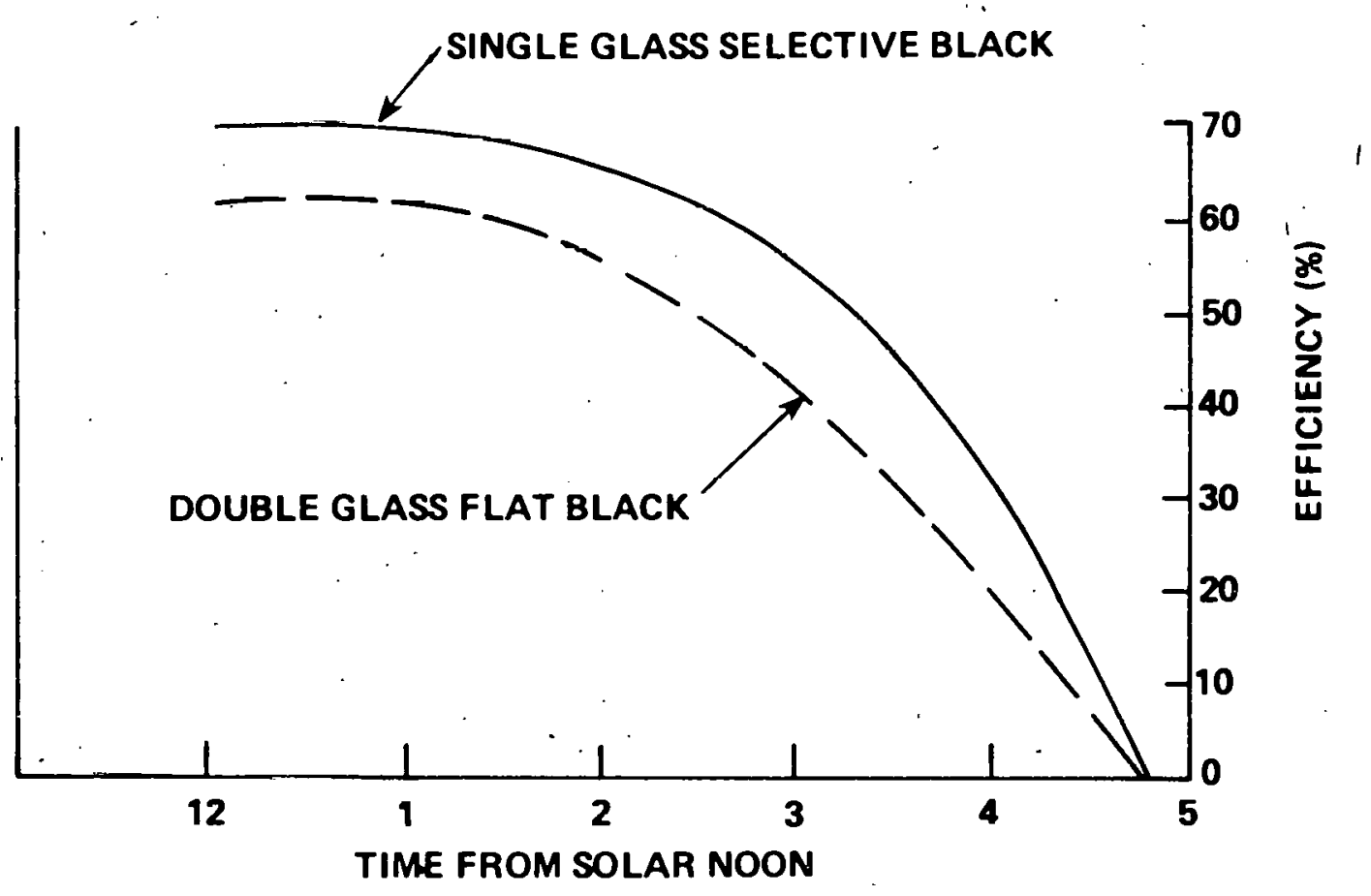

SOLAR COLLECTION TEST JANUARY 9, 1973

Figure 5-8. Experimental Efficiencies of a Flat Plate Collector (Ref.68) 


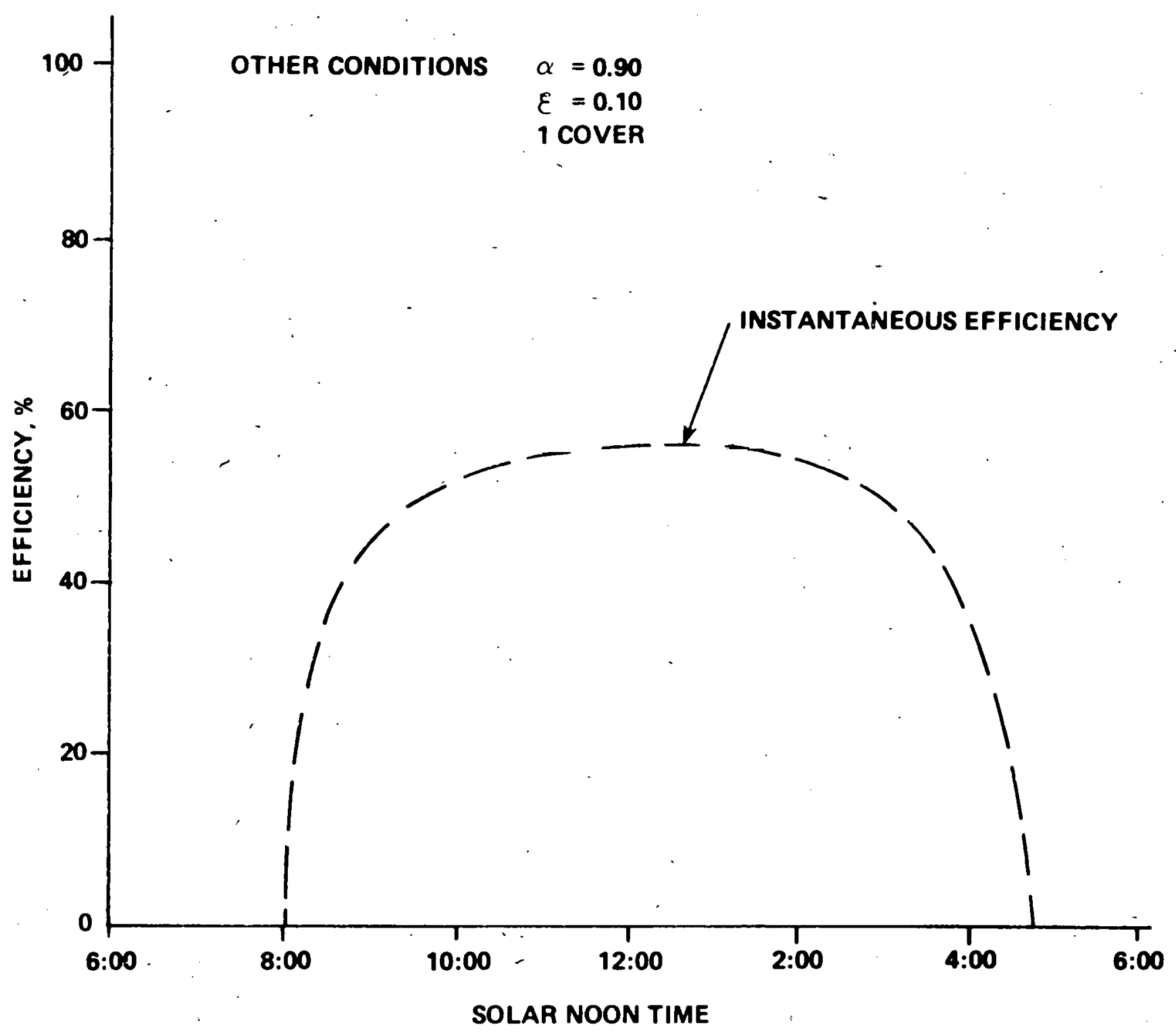

Figure 5-9. Diurnal variation of Theoretical Efficiency for a Flat Plat Collector with a Selective Surface and Cover (Ref. 104)

$5-19$ 
A consideration when comparing the flat plate collector with other types of collectors is the extent to which the collector tracks the sun on a daily basis. If the collector is stationary in a horizontal position, the plate will suffer cosine angle losses in the early morning and in the late afternoon. That is, the total collector area exposed to the direct radiation of the sun is effectively reduced by the cosine of the angle of incident light. Figure 5-10 (Ref. 37, fig. 9, p. 28) shows that if a flat plate collector is always normal to the sun rays (by tracking the sun), the energy collected. will be substantially higher. Cosine angle losses are common to all collectors that do not track the sun.

\section{4 CONCENTRATING COLLECTORS :}

Temperatures far above those attainable by flat plate collectors can be reached if a large amount of solar radiation is concentrated upon a rel-. atively small receiver area. Temperatures within a range of $300^{\circ} \mathrm{F}$ to $1200^{\circ} \mathrm{F}$ are easily obtainable with concentrating collectors (Ref. 4l). Even higher temperatures are possible, up to $6300^{\circ} \mathrm{F}$ with circular parabolic mirrors, if they are fabricated with a high degree of optical perfection (Ket. 3\%, p. 57). Hellustals drlälyed in a collcction field and dir. ected to focus on a central receiver can produce $1250 \mathrm{psig}, 950^{\circ} \mathrm{F}$ steam for thermal power production (Ref. 73). Because of the apparent movement of the sun across the sky, conventional concentrating collectors must be able to follow the sun during its daily motion. They can use only the direct rays of the sun because diffuse radiaticn cannot be focused.

Many different kinds of concentrating collectors have been proposed. Paraboloid concentrators, resembling searchlight reflectors, can attain extremely high temperatures, but they require very accurate tracking 


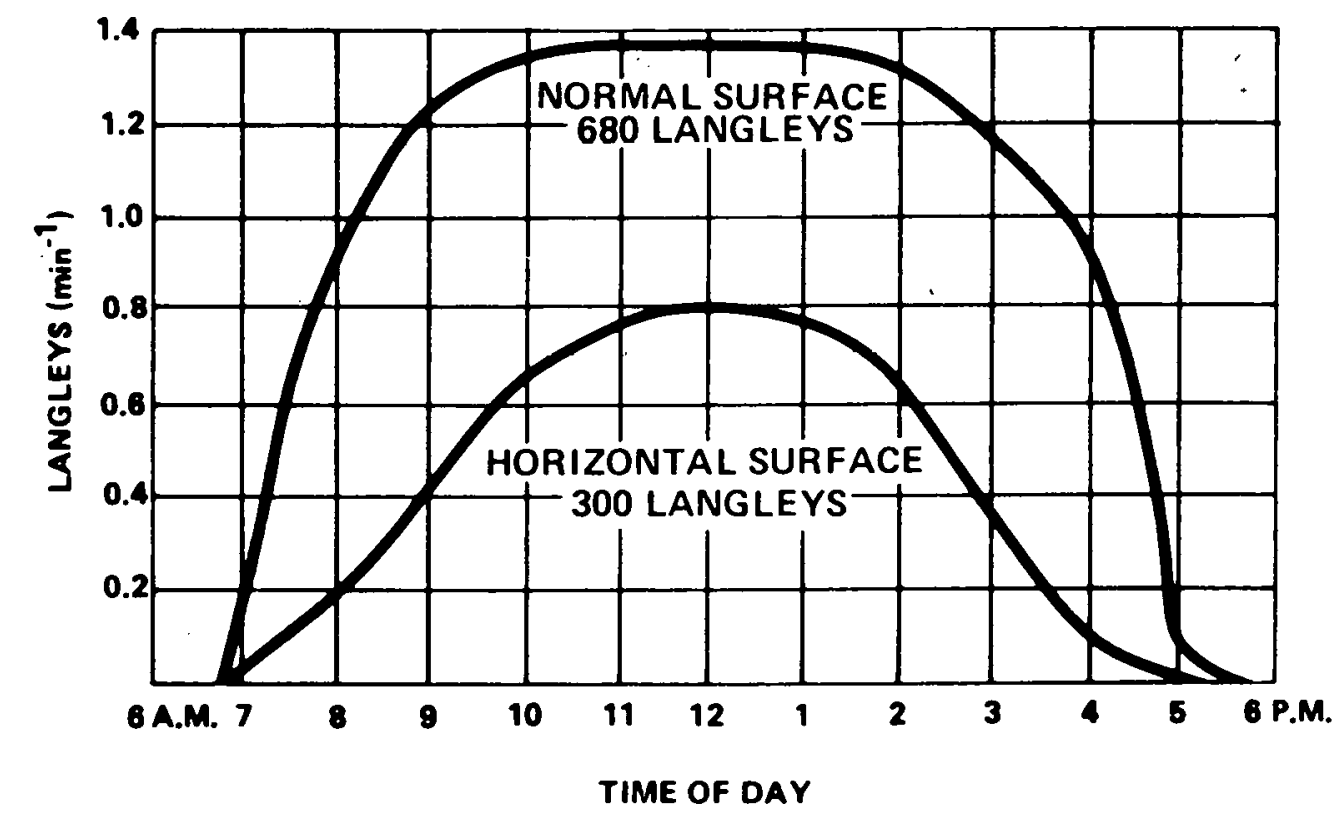

Figure 5-10. Radiation Received on a Normal Surface and a Horizontal Surface in Late October at Madison, Wisconsin. Latitude $43^{\circ} \mathrm{N}$. (Ref. 37) 
systems. Reflective troughs with parabolic cross-sections, running east and west, require the minimum amount of adjustment, because they need only to be adjusted each week or day so that the receiver is in focus for most of the day (Ref. 37, fig. 9, p. 28).

The cross-section of a concentrator need not be a parabola, so spherical or other dish-shaped concentrators have been considered. One variation of the spherical shape has been proposed with a tracking receiver and a stationary reflector, as illustrated in Figure 5-11 (Ref.109). Instead of focusing to a point, the spherical cross-section focuses along a line, and the theoretical concentration ratio (ratio of projected frontal area to sun image area) is approxima tely 200.

Other concentrating collectors in addition to the compound parabolic concentrator ( $C P C$ ) are designed for concentration ratios between $\mathrm{Xl}$ and X10. Wormser Scientific Corporation has designed an optical collector system applicable to home heating and cooling with concentration ratios that range from $X 2$ in the summer to $X 3.3$ in the winter (Ref. 134). The Solergy collector (Ref.110) is a cylindrical reflecting concentrator with an inward-spiraling cross-section. The sun's rays, once entering the spiral, cannot escape and are reflected deeper into the spiral, ultimately striking the absorber. The concentration ratio varies during the day from below $\mathrm{Xl}$ in the early morning and late afternoon to. X5. 5 at noon.

Another cylindrical reflecting concentrator that is similar in appearance to the CPC is the University of Houston grooved collector (Ref. 59, fig. 6, p. 21). This collector consists of long parallel grooves of trapezoidal cross-section as illustrated in Figure 5-12. Concentration ratios between $X I$ and $X 3$ are 


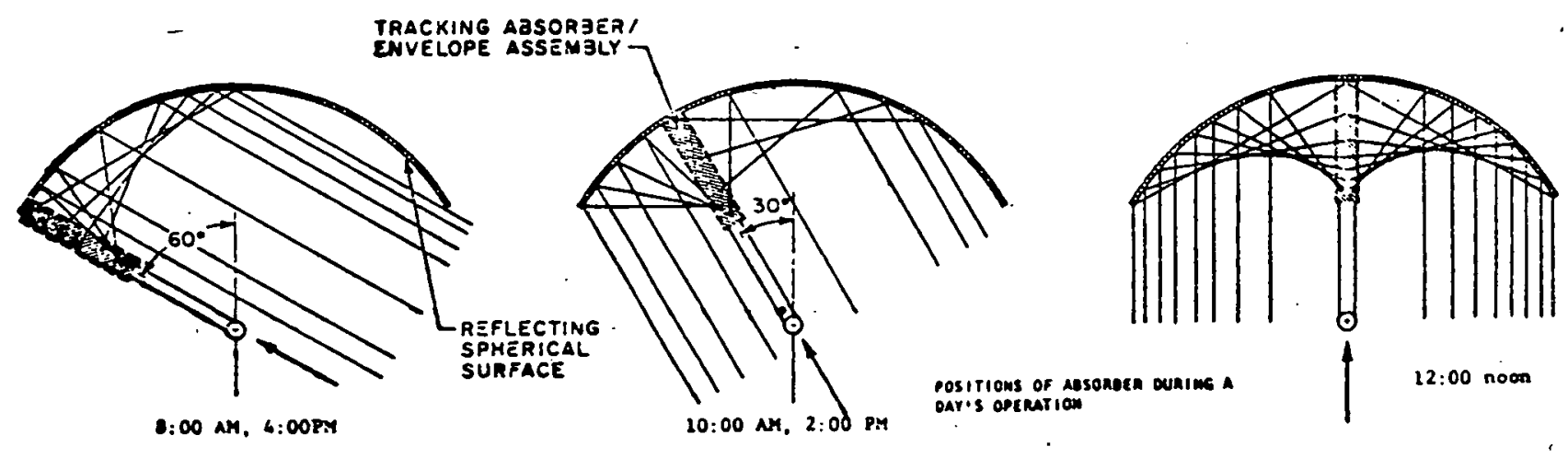

Figure 5-11. Stationary Spherical Concentrator with a Moving Receiver (Ref. 109)

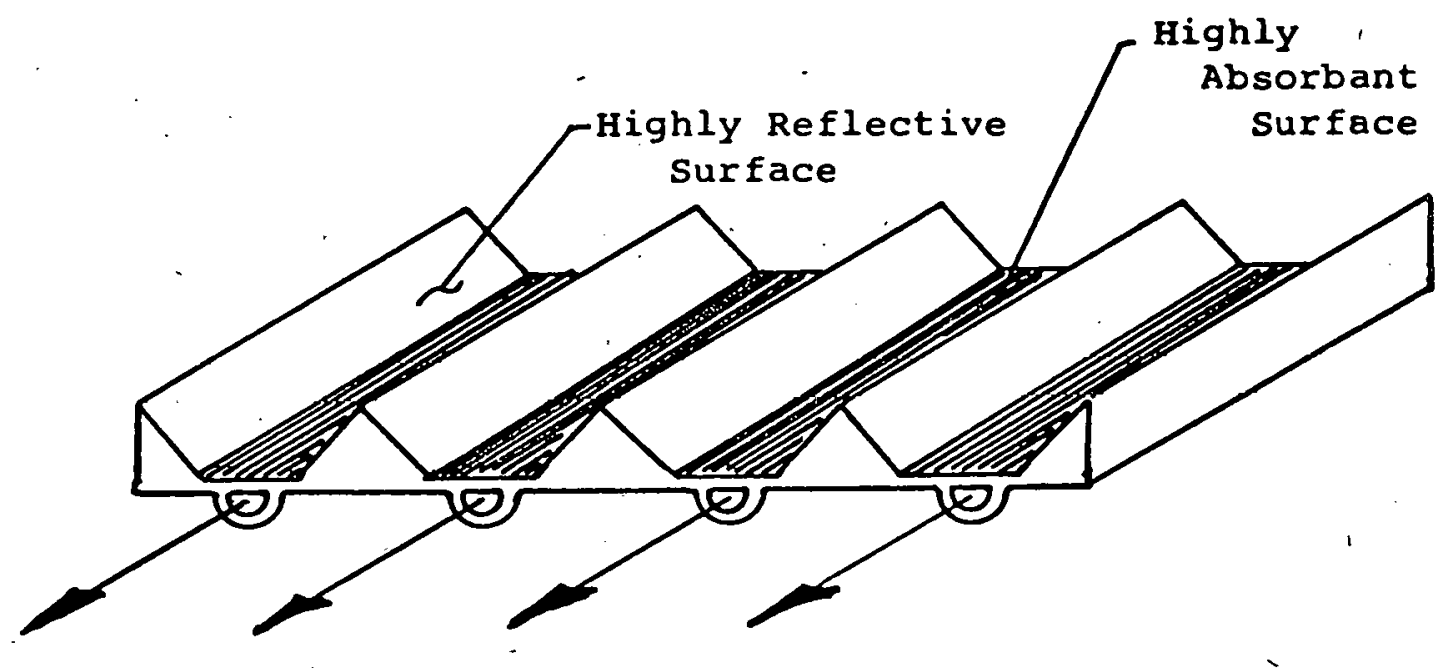

Figure 5-12. Moderately Concentrating Grooved Collector (Ref. 5.9) 
obtainable with his design (Ref 59). The University of Houston has evaluated variations of the basic geometry and analyzed optimal designs. Their work has been directed at moderate collection temperatures (i.e. , $200^{\circ}$ to $400^{\circ} \mathrm{F}$.).

\section{A COMPARISON OF EFFICIENCIES AS A FUNCTION OF $\triangle T$ (RECEIVER TEMPERATURE MINUS AIR TEMPERATURE)}

Figures 5-13(Ref. 59, fig. 6, p. 21) is a comparison of theóretical collector efficiencies for various collector designs, including a grooved collector having a concentration ratio of close to X3 (X2.8). Since the assumed conditions for these curves are similar to those used for the CPC performance curves in Figure 5-4, a comparison of collector efficiencies can be made at different $\Delta T^{\prime} s$, as given in Figure 5-14. For the four types of collectors shown (the dot dashed curve is Corning's published performance) the assumed heat loss coefficient and assumed solar insolation are approximately the same. A CPC with a concentration ratio of $\mathrm{X} 3$ was selected for the comparison because it has a concentration ratio that nearly equals that of the grooved collector. It is apparent from Figure 5-14 that collector efficiencies are higher for the X3, CPC than for the grooved collector. Two additional disar. vantages of the grooved collector, with planar reflectors, when compared to a similar CPC, are more reflections (on the average) and more mirror area for the same concentration ratios. The evacuated tube collector is shown to have the highest efficiencies, although having a selective absorber gives it an advantage over the other three collectors. The use of vacuum appears to have produced a significant improvement.

The parabolic trough collector that was designed and tested by Minneapolis Honeywell, has an optimal concentration ratio of X20 (Ref. 81 , p. 4) and 


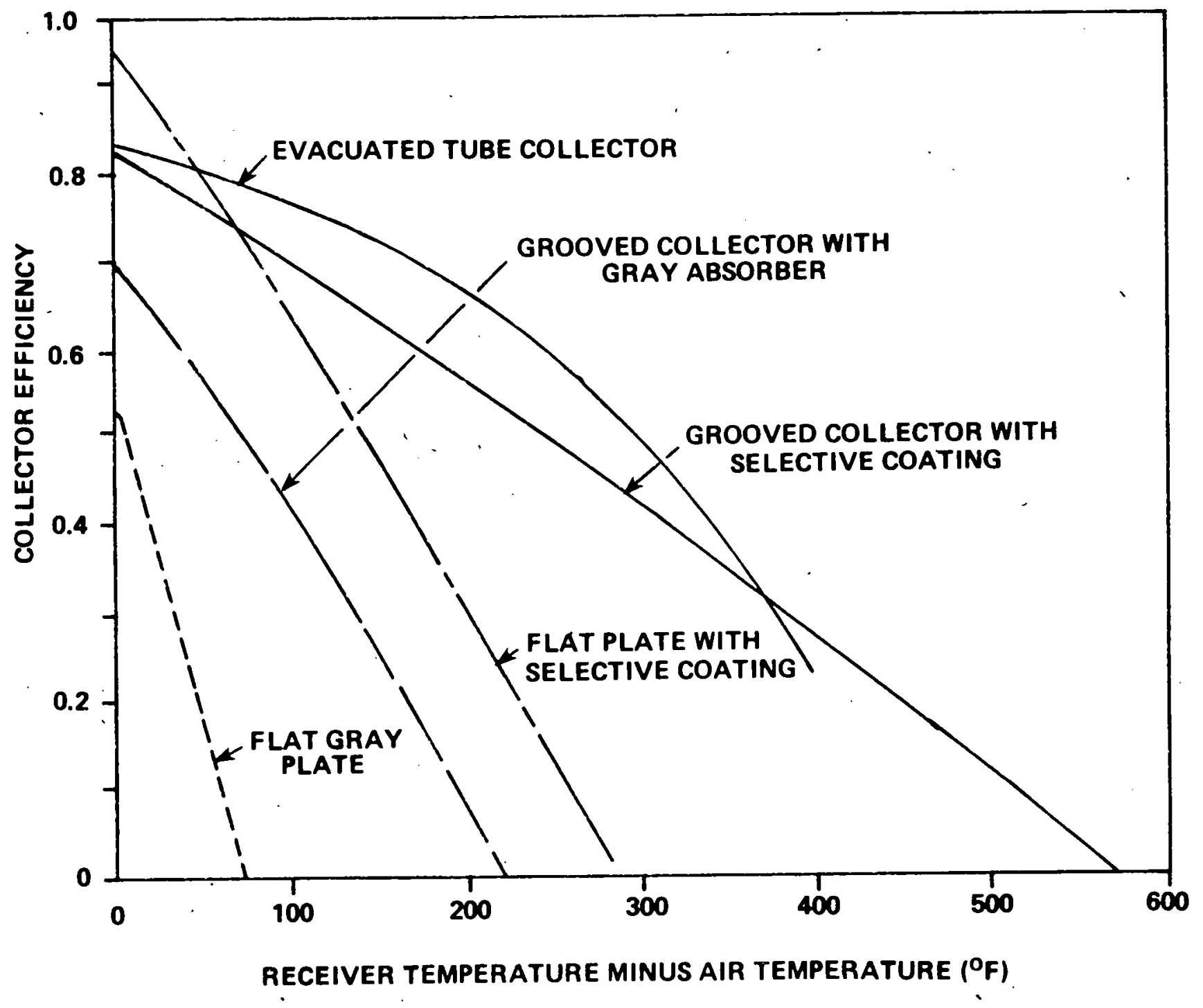

Figure 5-13. A Comparison of Collector Efficiencies for Various Collector Designs (Ref.59) 


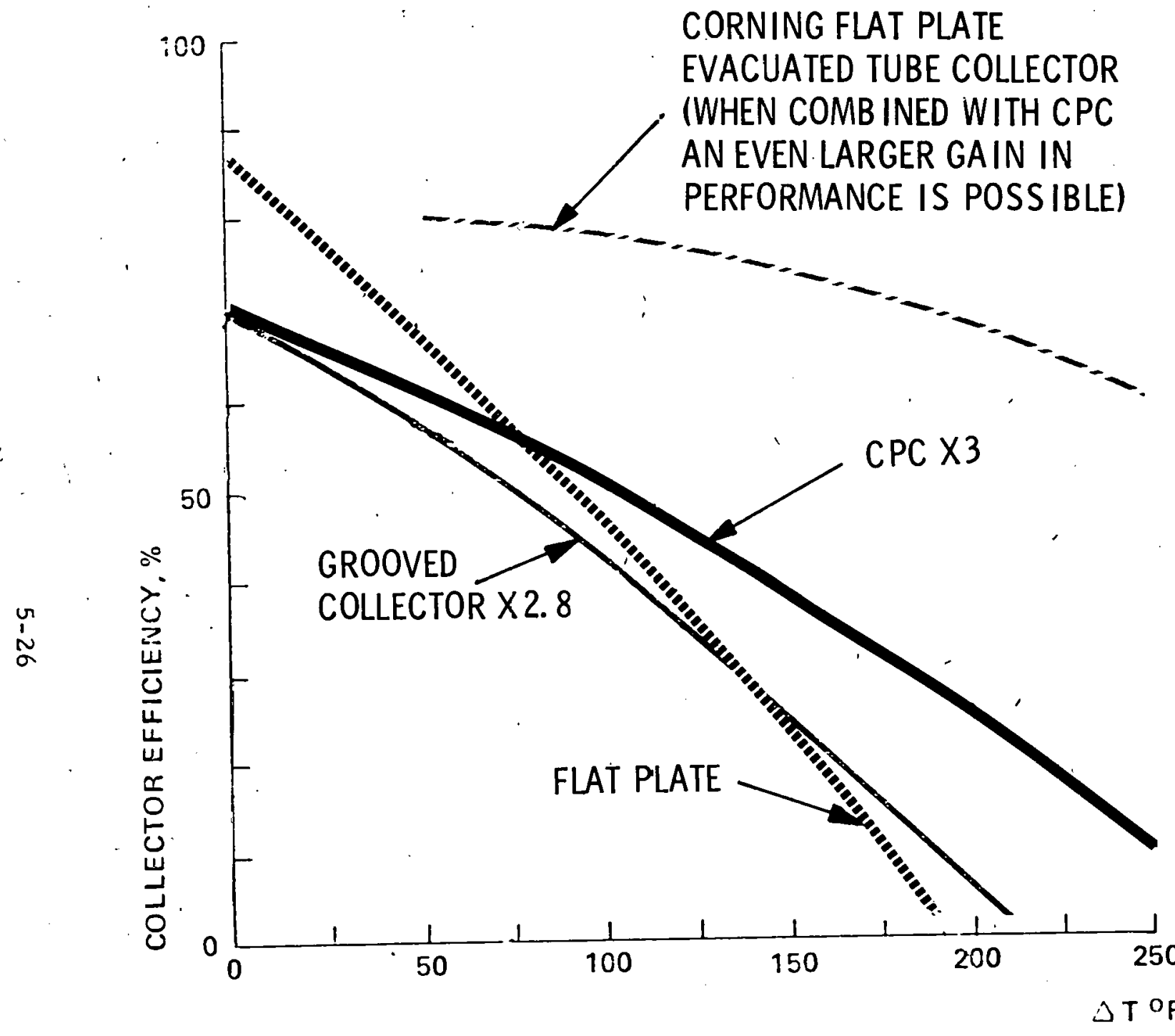

FIGURE 5 - 14

A COMPARISON OF CFFICIENCIES AS A FUNCTION OF $\triangle T$ (RECEIVER TEMPERATURE MINUS AIR TEMPERATURE) FOR FOUR COLLECTOR DESIGNS. 
operates with receiver temperatures as high as $570^{\circ} \mathrm{F}$. When the collector's axis is aligned in the east-west direction, the maximum collector efficiency is about 50\%. Figure 5-15 (Ref. 83, figs. 3-10, pp. 3-16) shows an experimental plot of efficiencies versus time of day for the east-west collector orientation. In the north-south orientation, the collector efficiency reaches a minimum at solar noon, as shown in Figure 5-16 (Ref. 83, figs. 3-5, pp. 3-11) because the sun-trough angle reaches a maximum then. In both orientations the collectors were operated to track the sun continuously.

Since good performance data a re available for the Honeywell collector, it is chosen as a representative concentrating collector for comparison in Section 5.5. In some instances, references are also made to a generic class of concentrating collectors.

\section{5 "A SUMMARY COMPARISON}

The performance of the three basic collector designs, as defined in previous sections, is compared qualitatively in Tables 5-3 and 5-4. Two tables were included to compare the relative effects of tracking and non-tracking on the performance of the three collector designs. Only diurnal tracking is considered. The tables are intended to be rough guidelines for comparing collectors. They include general statements about the relative performance of one collector compared to another. Ŕanges in values are indicated where appropriate, and in some cases, these ranges may overlap for the three collectors being compared. Further studies will be required to quantify the information presented here. In addition the matrix should be expanded as required to include a large number of attractive candidates in each basic category. In Table 5-3, collector efficiencies and temperature are divided into two 


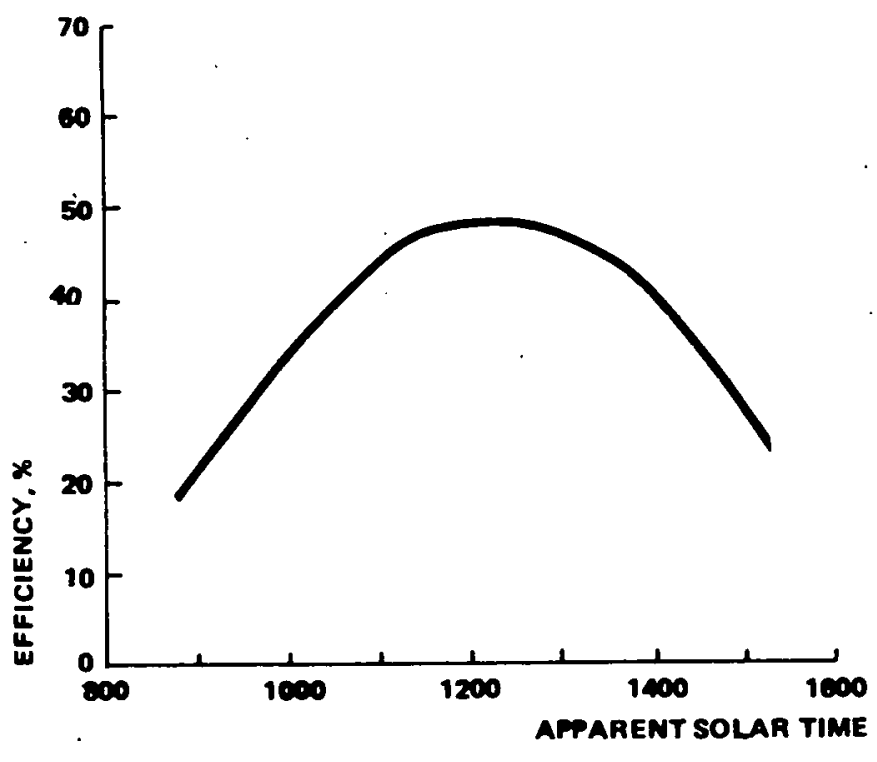

Figure 5-15. Efficiency Curve for the Honeywell Parabolic Trough Collector in the East-West Orientation $570^{\circ} \mathrm{F}$ Receiver Temperature (Ref. 83) 


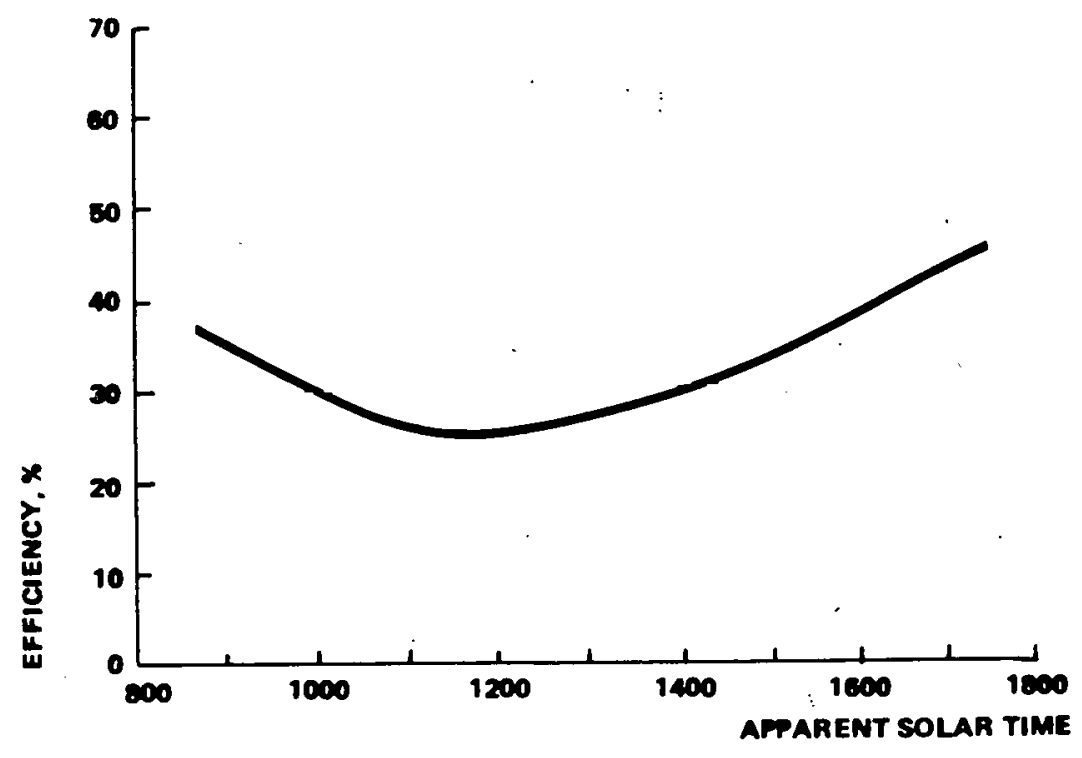

Figure 5-16. Efficiency Curve for The Honeywell Parabolic Trough Collector in the North - South Orientation $570^{\circ} \mathrm{F}$ Receiver Temperature (Ref. 83.) 
TABLE 5-3

STATIONARY COLLECTORS

\begin{tabular}{|c|c|c|c|c|c|c|c|c|}
\hline \multirow[t]{2}{*}{, } & & \multicolumn{2}{|c|}{ Collector Efficiency } & \multicolumn{2}{|c|}{ Receiver Temperature } & \multirow{2}{*}{$\begin{array}{l}\text { Optical } \\
\text { Efficiency }\end{array}$} & \multirow{2}{*}{$\begin{array}{l}\text { Concentration } \\
\text { Ratio }\end{array}$} & \multirow[b]{2}{*}{ Angular Acceptance } \\
\hline & & Solar Noon & Intograted Over Day & Solar Noon & Integrated Over Day & & & \\
\hline un & $\begin{array}{l}\text { Ermpound } \\
\text { farabolic } \\
\text { Cor:entrator } \\
\text { (CPC) }\end{array}$ & $\begin{array}{l}\text { 1. Higher } \\
\text { than flat } \\
\text { plate at } \Delta T \\
>100^{\circ} F \text { (a) } \\
\text { 2. Heat losses } \\
\text { are less than } \\
\text { for flat plate (b) }\end{array}$ & $\begin{array}{l}\text { 5. Higher than Iat } \\
\text { plate for large } \\
\text { acceptance angle } \\
\text { 6. Heat losges are } \\
\text { legs than for flat } \\
\text { plate }\end{array}$ & $\begin{array}{l}\text { 8. Higher } \\
\text { temperature } \\
\text { capability than } \\
\text { flat plate } \\
\text { collector due } \\
\text { ta ability to } \\
\text { concentrate } \\
\text { radiation }\end{array}$ & $\begin{array}{l}\text { 10. Temperature will } \\
\text { drop when } \theta>9 a a \text { (f) }\end{array}$ & $\begin{array}{l}\text { 12. Collects } \\
\text { all direct. } \\
\text { and some } \\
\text { diffuse radi- } \\
\text { ation }\end{array}$ & $\begin{array}{l}\text { 14. Nominal } \\
\text { range is from X3 } \\
\text { to } X 10 \text { (g) }\end{array}$ & $\begin{array}{l}\text { 16. Nominal range is } \\
\text { from } 5.7^{\circ} \text { to } 19.5^{\circ} \\
\text { (corresponding to con- } \\
\text { centration ratios of } X 10 \\
\text { and } X 3 \text {, respectively) } \\
\end{array}$ \\
\hline$\omega$ & $\begin{array}{l}\text { Flát Plate } \\
\text { Collector }\end{array}$ & $\begin{array}{l}\text { 3. Higher } \\
\text { than CPC at } \\
\triangle \mathrm{T}<100^{\circ} \mathrm{F} \\
\text { (ace 1) } \\
\text { 4. Flat plate } \\
\text { with oelective } \\
\text { absorber has } \\
\text { efficiency re- } \\
\text { ported to be } \\
\text { as high as } 70 \% \\
\text { (c) }\end{array}$ & $\begin{array}{l}\text { 7. Low efficiency } \\
\text { in early morning } \\
\text { and late afternoon } \\
\text { due to cosine argle } \\
\text { loso (d) }\end{array}$ & $\begin{array}{l}\text { 9. Low tem- } \\
\text { peratures, } \\
150-300^{\circ} \mathrm{F} \text { (e) }\end{array}$ & $\begin{array}{l}\text { 11. Low tempera. } \\
\text { tures compared to } \\
\text { CPC }\end{array}$ & $\begin{array}{l}\text { 13. Collects } \\
\text { all direct } \\
\text { and diffuse } \\
\text { radiation }\end{array}$ & 15. Equalo $X_{1}$ & 17. Approaches $90^{\circ}$ \\
\hline & $\begin{array}{l}\text { Concentrating } \\
\text { Collector }\end{array}$ & & performance of atat & onary (i) concont & ating collectors is insur & icient for com & parison. & \\
\hline
\end{tabular}


TABLE 5-4

DIURNAL TRACKING COLLECTORS

\begin{tabular}{|c|c|c|c|c|c|}
\hline & $\begin{array}{l}\text { Collector } \\
\text { Efficioncy } \\
\text { (Integrated) }\end{array}$ & $\begin{array}{l}\text { Receiver } \\
\text { Tomporature } \\
\text { (Integrated) }\end{array}$ & $\begin{array}{l}\text { Optical } \\
\text { Efficiency }\end{array}$ & $\begin{array}{l}\text { Concentration } \\
\text { Ratio }\end{array}$ & $\begin{array}{l}\text { Angular } \\
\text { Accoptanco }\end{array}$ \\
\hline $\begin{array}{l}\text { Compound Parabolic } \\
\text { Concentrator (CPC) }\end{array}$ & $\begin{array}{l}\text { 1. Higher than flat } \\
\text { plate due to lower } \\
\text { heat los se } \\
\text { 2. Higher compared to } \\
\text { stationary case } \\
\text { 3. Does not have } \\
\text { cosine angle loss }\end{array}$ & $\begin{array}{l}\text { 7. Higher temperatures } \\
\text { than flat plate } \\
\text { 8. Higher temperature } \\
\text { compared to otationary } \\
\text { case }\end{array}$ & $\begin{array}{l}\text { 11. Intercepts all } \\
\text { direct light, even } \\
\text { at } \theta>-8 \mathrm{aa}\end{array}$ & $\begin{array}{l}\text { 14. No change from } \\
\text { stationary case }\end{array}$ & $\begin{array}{l}\text { 19. Wide tolerance } \\
\text { for tracking accuracy }\end{array}$ \\
\hline $\begin{array}{l}\text { Flat Plate } \\
\text { Collector }\end{array}$ & $\begin{array}{l}\text { 4. Higher compared } \\
\text { to otationary case (j) } \\
\text { 5. Does not have } \\
\text { cosine angle loss }\end{array}$ & $\begin{array}{l}\text { 9. Higher temperatures } \\
\text { compared to otationary } \\
\text { case (j) }\end{array}$ & $\begin{array}{l}\text { 12. No change from } \\
\text { stationary case }\end{array}$ & $\begin{array}{l}\text { 15. No change from } \\
\text { stationary case }\end{array}$ & 20. N/A \\
\hline $\begin{array}{l}\text { Concentrating } \\
\text { Collector }\end{array}$ & $\begin{array}{l}\text { 6. Highest efficiencies } \\
\text { (Hone ywell collector) } \\
\text { occur at noon in E-W } \\
\text { orientation and in early } \\
\text { morning and late after- } \\
\text { noon (k) in N-S orienta- } \\
\text { tion. }\end{array}$ & $\begin{array}{l}\text { 10. High temperature } \\
300-1200^{\circ} \mathrm{F}(\mathrm{e})\end{array}$ & $\begin{array}{l}\text { 13. Collects min- } \\
\text { imal amount of dif- } \\
\text { fuse radiation. }\end{array}$ & $\begin{array}{l}\text { 16. Ranges from } 1+\text { to } \\
1000 \text {, depending upon } \\
\text { degign (l) } \\
\text { 17. Equals } 20 \text { for Honey } \\
\text { well collector (m) } \\
\text { 18. Concentrates only } \\
\text { direct radiation. }\end{array}$ & $\begin{array}{l}\text { 21. Narrow tolerance } \\
\text { for tracking accuracy (n) } \\
22 \text {. Approaches } 90^{\circ} \text { for } \\
\text { long troughs in } E-W \\
\text { orientation (Honeywell). }\end{array}$ \\
\hline
\end{tabular}


Footnotes for Tables $5-3$ and $5-4$

a. Refer to Figure 5-4

b. Refer to Table 5-1

c. Based on the maximum efficiency given in Figure 5-8 for solar noon assuming a selective black absorber surface and one cover.

d. Refer to curve for horizontal flat plate in Figure 5-10.

e. See Reference 41 , Table 1, p. 47.

f. When angle of direct ray is greater than the acceptance angle, no direct and only some of the diffuse light will be collected. Hence temperature will decrease rapidly.

g. See Reference 131.

h. See Reference 10, Table II

i. The Honeywell stationary collector will not focus incident light on the receiving a rea except at one time during the day (when the collector is aimed directly at the sun). Consequently, receiver temperatures and collector efficiencies will be low during most of the day. This will be true for all concentrating collectors that are designed to track the sun.

j. Refer to Figure 5-10.

k. Refer to Figures 5-15 and 5-16.

1. See Reference 37, p. 63.

m. See Keference 81 , p. 4

n. See Reference 83 , Figs. 3-10, p. 3-16, Figure 3-14. 
columns, one at solar noon and the other integrated over the collection period of a day, because the three stationary collectors compare differently at different times of the day. The collector efficiency and temperature at solar noon is the same for tracking collectors as for non-tracking collectors; and thus, the "solar noon" columns are deleted from the table in Table 5-4. A column for the number of reflections is not included in the tables, but its effect is included in the collector efficiency.

The words "about.equal", which are used in describing the comparative performances of collectors in Tables 5-3 and 5-4, mean that there are no large differences in performance, although the performance of one collector may be slightly better than another's, depending upon variations in design and conditions. Specific references a re made to the Honeywell collector whenever its performance is used to represent the class of concentrating collectors. In all other cases, concentrating collectors are treated as a generic class.

Tables 5-3 and 5-4 summarize the major features of the CPC's performance when compared to the flat plate and concentrating collector classes. Those performance characteristics of the CPC that excel over the other collector classes are highlighted below. Both performance and cost considerations are discussed in relation to potential CPC applications in Section 4. The CPC is expected to be competitive in those applications that fully exploit the following high performance characteristics:

- Higher temperatures are possible with the CPC than with the flat plate collector. 
- At receiver temperatures greater than $100^{\circ} \mathrm{F}$ above ambient air temperature, collector efficiencies are higher than for flat plate collectors.

- The CPC collects light entering at all angles less than its acceptance angle, whereas a concentrating collector focuses only the light entering parallel to its axis of symmetry.

- The basic optical element of the CPC can be adapted to either line focus (troughs) or point focus (dishes). Unlike a concentrating collector which must track the sun to perform satisfactorily, the CPC performs well as either a stationary collector or a tracking collector.

- The design of the CPC can be adapted to local climatological conditions. For example, in locations having some cloudy weather, CPC designs with lower concentration ratios (to accept more diffuse light) would be appropriate. Conversely, higher concentration ratios may be desirable where clear weather is prevalent and where there is a need for the higher collection temperatures required by absorption air conditioning. In addition, the CPC can be combined with secondary concentrating collectors to obtain concentration ratios far greater than X10. 


\section{Section 6}

\section{CONVENTTIONAL ENERGY COMPETITION}

\subsection{GENERAL}

Retail prices of various forms of energy to the consumer vary considerably, depending on distribution net, location, tax structure, profit margin, type of consumer, and on the dictates of the Organization of Petroleum Exporting Countries (OPEC). This study limited the initial information search to residential, commercial and industrial prices for coal, gas, heating oil and electricity on a national average. The price range for energy competition with the major CPC solar applications in 1975-1985 will be at the average consumer level, stated in terms of 1975 dollars per million Btu.

\section{2 OIL AND GAS}

The Federal Energy Administration (FEA), Monthly Energy Review, February 1975 (Ref 85), provided data on heating oil for November 1974. These data have been converted to $\$ / \mathrm{MMBtu}$ at $143,000 \mathrm{Btu} / \mathrm{gal}$ and are shown below:

\begin{tabular}{lc} 
No. 2 Fuel Heating Oil (November 1974) \\
\hline$\frac{\text { \$/MMBtu }}{2.65}$ \\
Residential & 2.65 \\
Institutional \& Utility & 2.37 \\
Industrial & 2.53
\end{tabular}

The U.S. Department of Labor, Bureau of Labor Statistics, (Ref 102) presents retail price data for No. 2 fuel oil and residential heating gas for March and April 1975. When these data are converted to $\$ / M M B t u$ the following are the results.

Oil and Gas (April 1975)

$\$$ /MMBtu

No. 2 Fuel Oil

2. 64

Gas, Residential Heating

1. 57 
It should be noted that the Bureau of Labor Statistics also lists a retail price index combined for fuel oil and coal. The list is a single column of indices by states that represents both fuel oil and coal. The conclusion is that the retail price of fuel oil and coal are parallel. Data on the retail price of coal were not included.

The American Gas Association provides data on U.S. total gas sales and revenues for 1973 and 1974 (Ref 3). When these data are converted to \$/MMBtu at $1,000 \mathrm{Btu} / \mathrm{SCF} *$ the following table may be developed.

\begin{tabular}{lll}
\multicolumn{1}{c}{ Natural Gas } & $(1973-1974)$ \\
& $\frac{1973}{193 B t u}$ \\
Residential & 1.25 & $\frac{1974}{1.38}$ \\
Commercial & 0.95 & 1.08 \\
Industrial & 0.50 & 0.64
\end{tabular}

\section{3 PROPANE - SPECIAL CASE}

Propane (bottled gas) is a special case which is very much in transition. A National Liquid Propane Gas (LPG) Association spokesman states that the current wide variance in prices can be attributed for the most part to the FEA price regulations in effect since Iray 15, 1973. The efferts of fuel allocation policies, availability of Canadian and offshore product and the pending proposals before the FEA to establish two separate price levels for propane contribute enormously to the uncertainty of future price levels. Surveys by the Department of Agriculture on farm use of propane and by the Butane-Propane News of Arcadia, California, point out that the wide discrepancies in pricing and availability are likely to continue in the near future. However, a stabilizing factor is seen in the possibility of administratively controlling the price of offshore propane landed in the U.S. to 30 to 35 cants per gallon, to which must be added both transportation charges and normal mark-up for sale to the consumer. At $91,000 \mathrm{Btu} /$ gallon, the landed price of offshore product would create a price

*Btu/SCF: British Thermal Unit per Standard Cubic Foot. 
floor of from $\$ 3.30$ to $\$ 3.85$ per MMḄtu. In summary, FEA price regulation is designed to benefit the rural heating market. For commercial and industrial users, and, in particular agricultural users, where dependency on this fuel is acute, the outlook is for diminishing domestic supplies of natural gas, from which propane is stripped, and for continuing volatility in the market for propane during the next decade. Present price ranges of industrial propane reported by $\mathrm{Cal}$, Gas for the west, rocky mountain and southeast is 2.20 to 5. $49 \$ /$ MMBtu.

\section{4 COAL}

The price of fireplace grade coal for residential consumption was not considered to be germane to the purposes of the study, as its market is not significant. No suitable reference to the price range for coal has been given in this report.

\section{5 SUMMARY - CURRENT PRICE LEVELS}

The following are estimates of the ranges in prices of various fuels for residential, commercial and industrial heating purposes as a national average. The prices are customer retail for the period of late 1974 or early 1975 in terms of dollars per million Btu. The upper level is representative of hou sehold or residential use while the lower value is representative of commercial use.

Various Energy Forms $(1975)$-Representative U.S. Price Ranges
$\begin{array}{ll}\text { Coal } & \frac{\$ \text { MMBtu }}{\text { N. A. to } 5.42} \\ \text { Natural Gas } & 0.56 \text { to } 1.48 \\ \text { Propane (Bottled Gas) } & 2.20 \text { to } 5.49 \\ \text { Oil } & 2.37 \text { to } 2.65 \\ \text { Electricity } & 3.85 \text { to } 7.82\end{array}$


6. 6

Numerous attempts have been made to project energy prices. Some of these rely on a prediction of the forces of supply and demand. In fact the price of crude oil in the United States in 1980 and 1985 may well be a consequence of political decisions and much less an outcome based on world market forces.

Since the present international price of crude oil is much higher than the so called "lifing cost" of most oil reserves, it could be expected that further, large fluctuations in international oil prices could occur.

For purposes of the initial phase of the goals study, current prices of various energy forms were projected in the accompanying Figure 6-1, using a price escalation factor of 7 percent over the next year, 6 percent in the following year and 5 percent thereafter, as suggested by Sherman H. Clark Associates, Consultants in Energy Economics, in a private communication. 


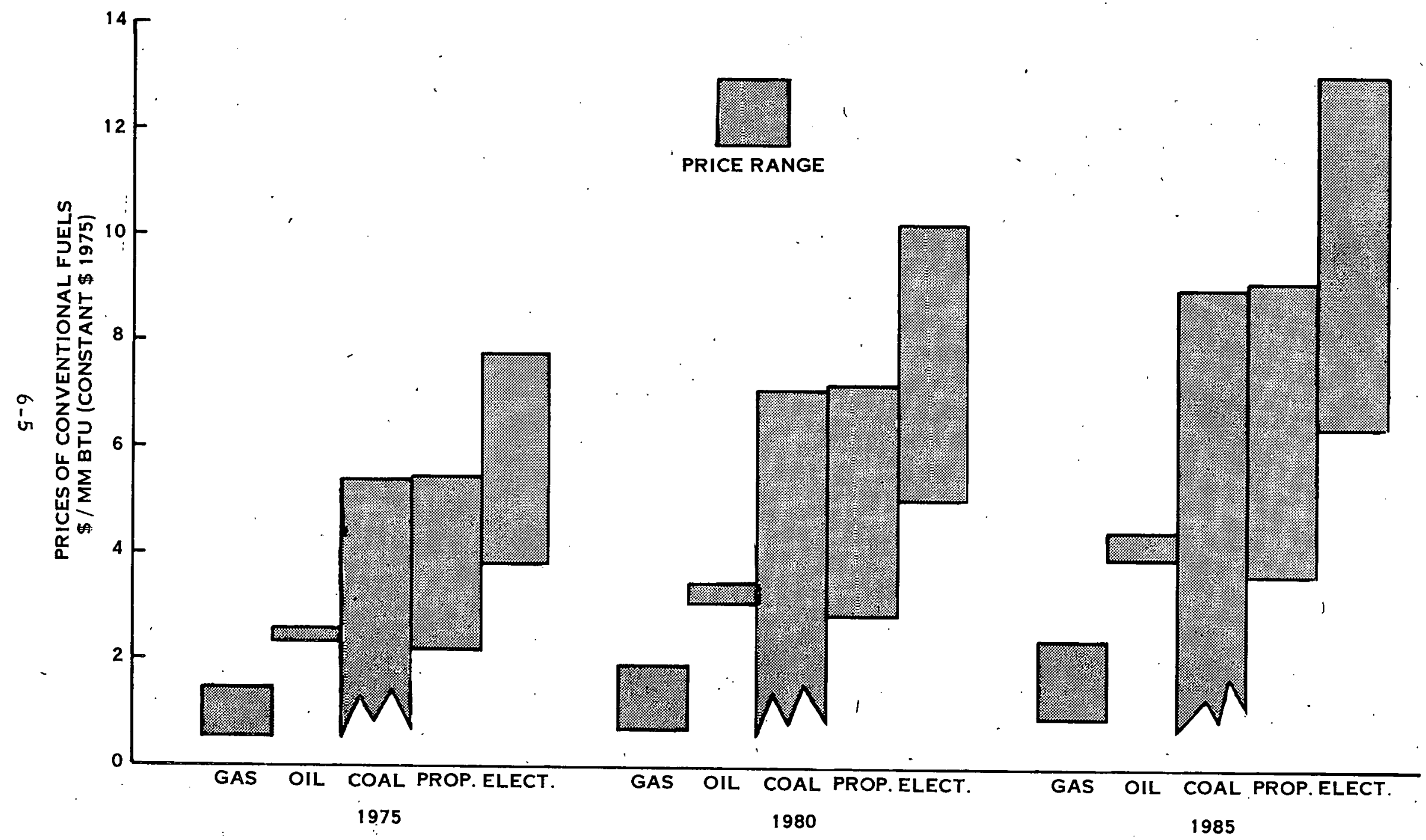

Figure 6-1. Fuel Price Projection for Residential, Commercial, and Industrial Heating 


\title{
Section 7
}

\section{INDUSTR Y INVOLVEMENT}

\begin{abstract}
"The best way to characterize the building process today is not as a series of trades or professions, but as a series of attitudes and positions."
\end{abstract}

Gary K. Stonebraker

Director of Research

Building Systems Development Inc. August 1967

\section{1 INTRODUCTION}

This section views the development of the CPC solar collector as a potential innovation in the building construction industry. It pertains mainly to sociological and technological factors and anticipates some of the problems of introducing innovation. Some of these are methodological, some political and others are, perhaps, unique to the housing industry, such as those concerning the aesthetics of a man's home.

\section{2 DESCRIPTION OF THE BUILDING INDUSTR.Y}

\subsubsection{Participants}

The building industry in the United States is made up of many relatively small organizations. These organizations form themselves into larger groups. Each of these groups is likely also to have its own requirements met prior to the introduction of a new product, such as solar energy sources into the building construction. The following is a 
profile of these groups together with descriptions of their activities and their requirements of a new product:

- Professional firms (architects and engineers). The architect/engineer is the building designer and specifier. He requires technical data on specific building products from the manufacturer for designing and specifying; support in the form of a guarantee or at the very least, the manufacturer's reputation and reliable cost information for preparing his budget.

- General contractors and their subcontractors. The general contractor oversees installation through his subcontractors. The subcontractor furnishes and installs the elements which comprise the building and adjusts installed equipment to operating condition. The needs of this group include reliable sources of supply, on-time delivery, qualified technicians, reasonable costs (particularly as a great percentage of the work is acquired through competitive bidding), gua rantees similar to those required by the architect/ engineer, and proven p̄erformance.

- Materials suppliers. The materials supplier furnishes products to the subcontractor. He is the manufacturer's wholesale distributor. He requires a reliable product that he can sell with confidence, reliable sources of supply and reasonable prices which will allow him to bid competitively.

- Manufacturers of building materials. The manufacturer develops, makes and markets his products. Manufacturers need a market for their products and a competitive 
lead in that market (either through patents or by being ahead of their competitiors in the introduction of new products) to make the necessary research and development economically feasible.

- Construction workers and their unions. Construction workers and their unions are principally concerned with employment and all of its benefits. A new product which would displace labor or disrupt the normal distribution of work amongst traditional trades would create problems with this group. Such problems, when anticipated, can usually be resolved by negotiation.

- Local, state and federal government. Government provides controls over building through legislation to protect the health, safety, and welfare of the population. Through legislation, government provides the means to make safe structures, to protect the health of the community through controlled development, to stimulate or slow the economy by controlling the building industry as need seems to indicate. Local and state agencies are concerned with the safety of buildings which they control through their building codes and inspections. They are also concerned with the protection of health and welfare. 'This is accomplished by controlling development through zoning which sets allowable land use, land coverage, building size in relation to its lot, and like matters. In reference to solar collectors, local and state authorities would be primarily concerned with safety. Can the collectors be soundly constructed and installed so as to resist normal wind and earthquake forces? Do they have adequate strength to support themselves plus additional loads such as snow? 
They would also be concerned as to the effects collectors might have on the quality of neighborhoods. Will they exceed height limits in order to catch the sun? Will they block views, require excessive land coverage, create disturbing reflections, or in any other way disrupt the continuity of an existing neighborhood? The federal government is concerned with the building industry as it affects particular social problems such as the production of low cost housing, the development of transportation systems, the renewal of our cities. The application of solar energy systems is of particular interest in light of our current energy crisis.

- Entrepreneurs initiate the development of property.

- Financial backers provide monies that are needed first for planning and construction (short term), and then long term mortgage money for the completed project.

- Brokers and realtors sell, rent, and manage property. Entrepreneurs, financial backers, brokers and realtors share the common concerns of financial soundness and marketability. Their primary interest in a technical innovation relates to its effect on these two factors.

Marketing requirements differ radically for different building types; those for housing, for example, have little similarity to those for office buildings, at least in the application of new technology. Tradition is strong in the mind of the home buyer. A solar collector which alters the traditional appea rance of a house could be a serious handicap in sales. In office buildings, on the other hand, the latest technology could be a sales asset as long as it does not conflict with what is currently in vogue nor too seriously affect costs or rents. 
7.2.2 Change and Innovation - A Review of Past Experience in the Building Industry

In considering the introduction of a new sola $r$ collector to the building market, it is well to have some understanding of how innovations have been brought about in the building industry in the past and some sense of the changes which are occurring in the industry today. It was previously mentioned that the building industry comprises a number of groups, each of which in turn is made up of many small firms. For example, in 1967 it was estimated that there were 35,000 general contractors in the United States and 9,800 architectural and engineering firms (Reference \#106). Unlike other major industries in this country, such as the automobile industry, no single group dominates the building industry, no single organization has the strength either in dollars or in a share of the market large enough to affect any major changes. Changes to date have been evolutionary rather than revolutionary. Many small changes have occurred over the years and many of these in turn have been organizational rather than technical. There is, however, a trend towards bigness in the building industry today and, as a result, a borrowing of certain techniques from other industries. The development of new factory-produced materials is causing the building industry to move away from the craft tradition and towards the tradition of factory production. For example, products such as gypsum board and plywood have replaced the hand applications of plaster for interior finishes and the nailing on of many small boards or shingles for exterior. Projects appear to be getting larger. Architects, engineers, planners, contractors, and so on often find themselves designing and building entire campuses rather than individual university buildings. Urban renewal projects can involve city blocks and more. The need to handle these projects has led to the need for increasingly larger engineering and contracting firms. The complexity 
of these large-scale projects, the social implications as well as the technical problems which they generate, are just beginning to be understood. New management techniques are required and are being brought into general use. These changes which have been evolving for the last ten to fifteen years are being accelerated by our current economic and energy crises.

\subsection{Underlying Concerns in the Industry}

Along with the tendency towards industrialization and towards consolidation in the building industry, there are many signs of portending change. Signs can be seen in the greater concerns for management displayed by contracting organizations; in the active search for new methods of design involving computer applications, team approaches and the inclusion of owners, community representatives and other than architectural disciplines in design decision-making; in ecological concerns as indicated by requirements for environmental impact statements; a developing interest in the effects of environment on behavior manifested by the new discipline of behavioral science and, of most importance to our subject, concern for the design of energy conserving buildings.

From the foregoing, we can see that the building industry is fragmented, that it is made up of groups with interests some of which encourage and some of which discourage innovation, that no single group dominates, that change has been evolutionary and that the process by which we acquire buildings is under serious scrutiny.

To say that the need for energy conservation and the search for new sources of energy are leading to significant changes in building design is to state a truism. It is equally evident that the se changes, though accelerated by current crises, are in fact part and parcel of general attitudinal changes. 


\section{3 SOLAR ENERGY AND THE BUILDING INDUSTRY}

\subsubsection{Economic Factors}

While the current energy crisis is bound to stimulate interest in the use of solar energy for space conditioning of buildings in the near future, solar devices for heating and cooling are unable to compete with traditional energy sources on a first-cost basis and, in the present state of their development, still require supplementation with conventional systems.

\subsubsection{Life Cycle Costing of Solar Systems}

It is only reasonable to evaluate the cost of a solar energy system today by the techniques of life cycle costing. This costing technique has been tested by the Department of Defense since 1965 (Reference 53). In summary, a cost analysis would include initial cost, maintenance and support cost, and useful life. Initial cost is relatively easy to determine. Useful life on tried and true products' is also easily established. Cost information on maintenance and support is not so readily acquired but the method has been developed to the extent where DOD feels that life cycle costing is a significant factor in the design of its buildings; while not applying it universally, they have used life cycle costing with satisfactory results on a number of buildings.

\section{3. 3 Dissemination of Solar Information to the Industry}

A very useful tool for the architect/engineer who has to specify a solar system would be a well-prepared brochure with factual information on such things as life cycle costing and guidelines for the determination

- of energy savings which would be realized by va rious modifications in building design as mentioned previously. Without these tools, solar energy systems could well be treated like wooden doors vs. metal doors 
or any other of those building parts which are specified in terms of their immediate impact with little, if any, thought for their long-term effectiveness.

\subsubsection{Incentives for Industry}

At the present, solar collectors appear to fall into that category of things which are socially useful but not immediately profitable enough to be marketed by a major manufacturer. This suggests the need for strong action on the part of government to encourage the use of solar energy systems. Government has a variety of tools that can be used to direct efforts to the immediate development and application of such useful products. These tools include monetary policy, fiscal policy, taxation, anti-trust laws, regulatory laws, development of standards, patent laws, procurement, labor laws, lending policy, control of natural resources, welfare programs, research and development, tariff, and quota programs. In reference to the application of solar energy, government can develop building standards for energy conservation, provide tax incentives, stimulate the use of these devices through its procurement policy for government buildings, offer loan incuranse, and many more. Some of these things are in effect today.

The foregoing has considered the structure of the groups which comprise the building industry and their primary criteria for the acceptance of solar energy systems. There remain design considerations, the questions of modularity and of responsibility.

\section{3. 5 Design Factors}

Solar collectors need full exposure to sunlight in order to function. As presently designed, collectors tend to be rather large. Plate collectors for example run in size between 25 and 50 percent of the 
total floor area of the building they serve depending on the extent of the energy generating system. The incorporation of objects so large into our built environment deserves the most serious design attention. As a generalization, architects tend to be interested in the formal and symbolic challenges to be found in the application of new technical devices with results which are sometimes good and sometimes not. The form an object takes will also affect its popular acceptance. Concern on the part of the general public regarding energy costs and energy conservation indicates no lack of public acceptance of solar heating and cooling systems. The popular concept of acceptable appearance, however, is frequently at odds with that of the designers.

\subsubsection{Aesthetics}

Many communities have design restrictions intended to maintain their character. Though it is difficult to enforce laws dealing with aesthetics, efforts to do so must still be acknowledged in the application of a new product.

\subsubsection{Integration with Buildings}

Solar collectors can be integrated into a structure, or placed on the ground nearby. They can be independent of, but on the roof of a building, or they can be incorporated into the roof such as in a gable or hipped roof house. As a general observation, the integrated approach would most likely be the appropriate one for houses, for the individual home owner has a very strong image of what a house should be.

Because of the need for the best orientation for sunlight, the incorporation of collectors into the roof of a building of necessity dictates the orientation of the building regardless of other factors, such as the slope of the land, which might otherwise suggest other orientations. 
In the case of buildings where the solar collector is its own structure, it need not be on axis with the building. With the collector as an independent device, the building can be oriented according to the sun. On tall buildings such as highrise office buildings, solar collectors might be designed to project from the walls acting both as sun shades and as collectors. This offers the double advantage of catching the summer heat outside rather than inside of the building while providing a large potential area for collection.

\subsubsection{Modula rity}

Much has been said of the need for modular sizes for solar collectors. The building industry has fallen into the $4 \mathrm{ft} \times 8 \mathrm{ft}$ module for historical reasons which need not be discussed here. In the application of a product, its size, in addition to functional requirements, should be dictated by the dimensions of the building. This is a way of saying that the custom sized part has the most general application. Where the manufacturing process does not economically permit the production of custom sizes, then some pre-determined.range of dimensions for the product must be established.

\subsubsection{Legal and Social Factors}

There are legal and social as well as aesthetic implications to archi- tectural design incorporating solar collectors. These were referred to briefly in the preceding comments about design controlled communities. Such things must be considered as the creation of undesirable reflections which would be a disturbance to neighbors and the protection of sun rights. 


\subsubsection{Maintenance Problems}

Dirt and dust appear to have a minimum effect on the effectiveness of solar collectors. The periodic washing that normal rainfall provides appears to be adequate.

\subsubsection{Criteria for Industry Acceptance}

Solar energy systems undoubtedly will be accepted as part of a total approach to better energy ulilization in design and construction of buildings. There are, however, conditions which apparently will have to be met for their acceptance. Proven performance is essential for the architects, engineers, and contractors who have ultimate responsibility for the design and construction of buildings. Government support will be required in research and development and in the creation of incentives for application through financial benefits. Restrictions on other forms of energy consumption may also arise, adding to the desirability of relying on solar energy. Attention will have to be paid to the architectural design, not so much of the collectors themselves, but of their installation for popular acceptance. Legal consideration must be given to such matters as the protection of sun rights and the general effect of solar collectors on the community as a whole.

\subsubsection{Recommendations}

To encourage the acceptance of the Compound Parabolic Concentrator, Argonne National Laboratory might do the following:

(1) Complete the ANL goals study. Include, among the many other aspects, the following:

- A look at solar energy systems in total with consideration for both technical and labor problems in installation, for cost and anticipated services, for zoning problems and related problems of general public acceptance. 
- Identify and recommend financial incentives and cost effective designs of solar systems to encourage the manufacture and use of solar energy equipment.

(2) Develop conceptual designs of promising systems incorporating

- the CPC design concept, including all structural details of significance, heating, ventilating, and air conditioning (H.VAC) details and cost analyses.

(3) Initiate hardware programs that will accelerate the commercial development of the CPC collector in close cooperation with industry:

- Develop conceptual and preliminary designs of the most promising CPC systems.

- Contract for the fabrication of prototypes.

- Continue testing the CPC collector prototypes at ANL.

- Initiate standard product testing of manufacturing prototypes.

(4) Undertake a major dissemination program within the building industry:

- Develop useful data and specification information to assist the architect/engineer. This information could include charts and other data enabling the designer to look at energy-using implications of his building as a whole.

- Publish a guide to the techniques of life cycle costing, using examples that apply to the major potential appli-. cation of the CPC collector.

These actions can contribute significantly to the acceptance of solar energy devices in general and the Compound Parabolic Concentrator in particular by both the public and the building industry. 


\section{PRIORITIES FOR DEVELOPMENT PROGRAMS}

In this section, the relative priorities for the photothermal collector development program and the photovoltaic collector development program are given.

8.1 PRIORITIES FOR PHOTOTHERMAL COLLECTOR DEVELOPMENT PROGRAM

\subsubsection{Complete CPC Goals Study}

The initial phase of the goals study was conducted on a level-of-effort basis in six weeks' time. It served to prepare cursory groundwork for. outlining the CPC development program. Potential applications have been identified, design and manufacturing criteria have been determined, and a methodology for setting cost goals has been presented.

To complete the goals study, the above topics should be examined further to convert qualified development criteria into functional quantified developmental goals. Topics including marketable production potential, CPC systems' performance and competitive costs should be investigated further to provide quantifiable goals.

\subsubsection{Engineer CPC Collectors Suitable for Commercialization} CPC solar collectors must be durable, efficient and low cost. The development program should be directed toward engineering mass producible collector panels that adhere to the above three goals. To insure a commercially acceptable product having a potential for . wide-scale market diffusion, the panels must be integrable into building structures and must satisfy all applicable building codes. 
8.1.3 Coordinate with the Development of Ancillary Components Incorporated into many of the potential CPC systems applications identified in this study are ancillary components that require development in varying degrees if they are to be compatible with the systems. It is necessary that a coordinated design effort be initiated between the CPC collector designers and potential suppliers of ancillary components needed to insure availability of potential applications systems.

8.1.4 Develop Plan for Providing Technical and Economic Data to Industry

For the CPC solar collector market potential to be realized, a plan should be developed to transfer both technical and economic data from researchers and designers to the industrial sector. Such data should be disseminated to potential fabricators, distributors, dealers, builders and consumers on a wide-scale.

8.2

PHOTOVOLTAIC COLLECTOR DEVELOPMENT

As stated earlier, it was not possible in this cursory goals study to examine in any detail the application of the CPC to photovoltaic devices. Application of the CPS solar collector technology to photovoltaic solar cells should reduce effective cost and/or increase current density in ribbon or other silicon cell arrays, in small circular Ga As wafer arrays, (Ref 135) or in arrays of the other photovoltaic cells currently under development. 
Appendix A

STA TEMENT OF WORK

\section{Purpose}

This appendix to the final report provides a suggested work statement which defines the scope of a program that would provide a more detailed and complete study and/or program for the development of the CPC through turnover to industry for commercialization. Included is a preliminary cost estimate as well as tentative schedules for the accomplishment of the program.

2. Scope of Work

\section{1 General Scope-Absorption Cooling System Development}

The evaluation contained in the body of this report suggests that a viable application for the CPC solar collector design would be in the field of air conditioning utilizing absorption cooling principles. The challenge to reduce to practice would probably be most promising for early application to cooling systems for residential and many commercial buildings; $i . e .$, in the range of 5 to 25 tons of cooling. Therefore, a program was constructed to accomplish the development of a prototype absorption cooling system in two phases, and is graphically displayed in the logic diagram contained in Figures 1 and 2 . The first phase involves the orderly establishment of system goals and objectives, followed by preparation and approval of detailed design requirements. Once the "design-to" requirements are approved, the preliminary design will be prepared and a thorough analysis will be conducted to provide evidence that the preliminary design can meet the design requirements. On completion of the work, a preliminary design review is held at which time a decision to proceed or not to proceed can be made. Only a modest investment in time and resources will have been committed up to this point. Most probably, ANL should engage the services of an experienced systems contractor to conduct the bulk of the work under Phase I.

Should ANL decide to proceed to Phase II, the program then would expand to cover detail design of system components. Most probably this would concentrate 
on the collector design and on specific changes to commercial systems from gasfired operation to water-fired operation. After these efforts are initiated, it appears that the balance of the system would contain commercially available compo nents arranged in a custom system design and therefore would not require any additional development effort. Those components requiring evaluation would be fabricated and subjected to component evaluation testing. On achievement of satisfactory results, the next step would be to assemble a prototype demonstration test system and to conduct testing in an actual application situation. On completion of this system demonstration, the fabrication, assembly, and installation drawings along with the test and evaluation data would be documented and turned over to industry for commercialization. The Phase II investment would be more substantial than that for Phase I, but industry participation might possibly be obtained to help defray the costs or industry conceivably could assume total cost at the onset or at any stage of the development program. As in Phase $I$, it is suggested that ANL engage the services of a systems contractor to head this effort, with overview by ANL.

2.2 Deta iled Scope - Absorption Cooling System Development

\section{2:1 Establish System Development Goals}

In this first step, ANL should prepare a system development goals description for inclusion in a Request for Proposal (RFP) for the Phase I preliminary design contract. It should outline the state of development of the CPC design, prior work conducted, and the desired goals for further development.

\subsubsection{Establish System Design Objectives}

In this second step and also to be included in a RFP for the Phase I preliminary design contract, ANL in conjunction with HUD and other interested government agencies and possibly in conjunction with a consultant or a systems design contractor, should prepare a systems design objectives document which specifies design guidelines for an absorption cooling system incorporating the CPC design. This document should specify objectives such as systems size, cooling capacity, proposed geographical regions for application, location for installation, design life, reliability, safety, maintenance, interfaces with other systems, etc. It 
should also specify the depth and scope of analysis required in preliminary design, the format and content of specifications, and the requirements for conduct of a preliminary design review. On completion, the RFP should be is sued for bids, the bids reviewed, and a systems contractor should be selected.

\subsection{3-2.2.5 Prepare Design Requirements Specifications}

The selected contractor will prepare a conceptual design diagram to identify the system, subsystems, and components. The design objectives will be translated into requirements first for the system and then the contractor will allocate these requirements further to the subsystem and component level. The result will be a set of specifications forming the basis for preliminary design.

\section{2. 6 Conduct Design Requirements Review}

On completion of the design requirements specifications, ANL in conjunction with HUD and other interested government agencies, should conduct a formal review of these documents with the contractor and formally approve them.

\section{2.7 Conduct Preliminary Design .}

The contractor, utilizing the design requirements specifications, will proceed to devise a detailed to-scale systems layout which identifies all system hardware including size, location, materials, packaging and mounting, and other mechanical and electrical details. This system as well as ensuing interations will be subjected to detailed engineering analysis in the areas of (1) thermal and fluid flow, (2) structures, (3) controls, (4) safety and reliability, (5) manufacturing and installation costs, and (6) operational and maintenance costs. Iterations may be required to achieve a preliminary design which can meet the design requirements. A detailed plan for Phase II will be devised which also contains estimated costs and schedules for its accomplishment. The results will be documented and forwarded to ANL for review.

\section{2.8 Conduct Preliminary Design Review}

On completion of the preliminary design, ANL in conjunction with HUD and other interested government agencies, should conduct a formal review, with the con- 
tractor, to assess the probability that the preliminary design can reasonably meet the design requirements. An important consideration will be the comparati economics of the designs and the possibilities for commercialization. Should this prove attractive, then an RFP for Phase II should be is sued, bids evaluated, and a contractor (preferably the Phase I contractor) selected for the accomplishment of Phase II.

\subsubsection{Conduct Detailed Component Design}

Detail design of nón-commercially available components will be conducted and fabrication drawings will be made. Most probably the CPC solar collector unit will be the prominent area of design although there can be unique controls and mounting structures also involved.

\subsection{Fabrication Prototype Components}

Prototype components for test evaluation will be ordered and/or fabricated. Also orders should be placed for long-lead components, if any, for the prototype demonstration system.

\subsubsection{Test Components and Analyze Test Results}

Prototype components will be subjected to test as necessary to provide evidence that these components meet the requirments of the design specifications and are suitable for inclusion in the demonstration system. Short lead items for the demonstration system should be ordered during this period.

\subsubsection{Assemble and Test Prototype Demonstration System}

One or more test sites including actual residential or light commercial buildings will be selected and a prototype system will be installed therein. Testing shall be conducted for a sufficient time duration to demonstrate adequately that the prototype system meets its design requirements, to the satisfaction of both manufacturers and consumers as well as ANL. 


\subsubsection{Analyze Test Results and Document Data .}

The results from the demonstration system test program will be analyzed, performance data and operating and maintenance experience documented, and a final report written and submitted to ANL for review and approval.

\section{2. 14 Release Data to Industry for Commercial Application}

After suitable government review of the report and consideration of the possibility of government sponsored incentives for commercialization, ANL should release all data to industry for commercial application.

\section{3 Other CPC Related Work Scope}

There are additional items of work related to the CPC design which ANL should consider for continuation and initiation in FY 1976 as follows:

- ANL has (in-house) in process, a testing and fabrication program for developing CPC prototype solar.collectors. This program should continue and is a significant source of data support for the preliminary design program described above. It should be conducted in accordance with the design goals and priorities for development outline in the body of this report.

- ANL should consider the initiation of a program for testing promising CPC prototype collectors evolving from the in-house program, at outside agencies such as NASA test facilities, Underwriters Laboratories, Consumers Union, etc. Standard, environmental and in situ testing should be required.

3. Estimated Costs and Schedules

A preliminary estimate and schedule for the accomplishment of Phase I is included herein. Phase II was not estimated as it was felt that this should be made during Phase $I$ to arrive at reasonably accurate results. The estimated schedule is shown in Figure 3, and it indicates that Phase I will require 12 months to complete. Table I contains the preliminary cost estimate (contractor only) 
and indicates that approximately $\$ 238,000$ would be required to fund the program.

The data in Figure 3 and Table I were developed by Bechtel solely for guidance to ANL in assessing the magnitude of the preliminary design effort and does not represent an offer by Bechtel to accomplish this work. 
REPRESENTA TIVE PREĹIMINARY COST ESTIMATE

(CONTRACTOR ONLY)

Labor

Project Manager

Mechanical Engineer

Ther modynamicist

Instrumentation \& Controls Engineer

Structural Analyst

Safety \& Reliability Analyst

Manufacturing Engineer

Cost Engineer

Specification Writer

Program Planner

Technical Writer

Clerical

Drafting
Man-Hours

1200

1600

640

640

640

640

640

640

480

240

320

800

Total

$\frac{640}{9120}$
$\$$

36,000

40,000

16,000

16,000

16,000

16,000

14,000

14,000

9,000

6,000

:6,000

10,000

$\frac{11,000}{210,000}$

Other Direct Costs

Materials \& Reproduction

Communications

Travel

Consultants

Computer

$\mathrm{R}$ eports

Total

1,000

4,000

4,000

6,000

10,000

$\frac{3,000}{\$ 28,000}$

Grand Total

$\$ 238,000 * *$

* Program equivalent to 4.4 man-years **Includes burden and fee 


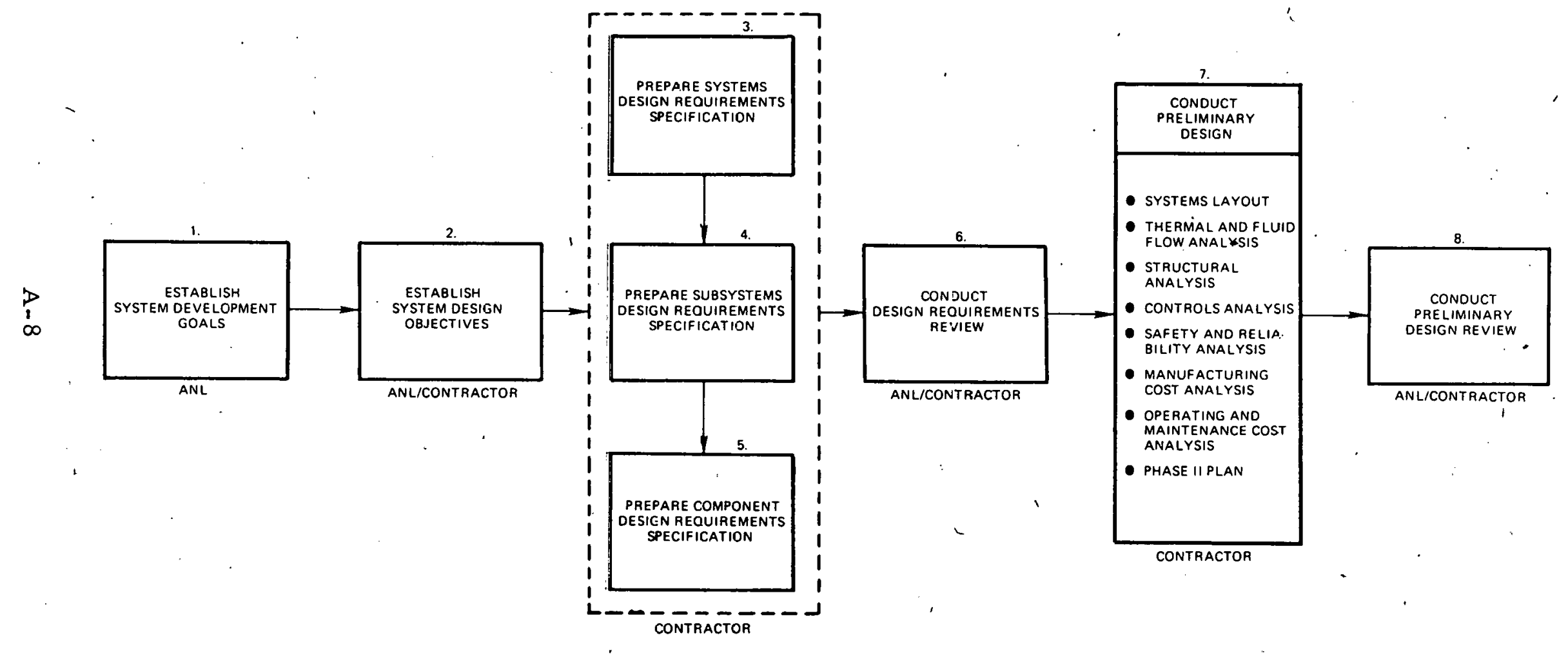

Figure A-1. Logic Diagram. Phase I- Preliminary Design 


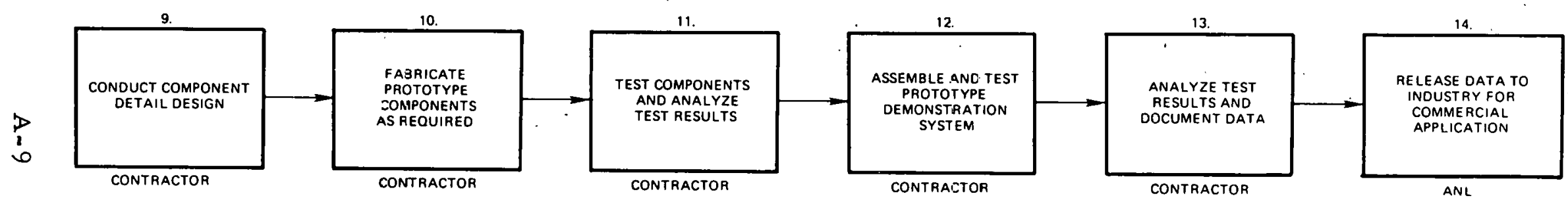

Figure A-2. Logic Diagram. Phase II - Detail Design and Evaluation 


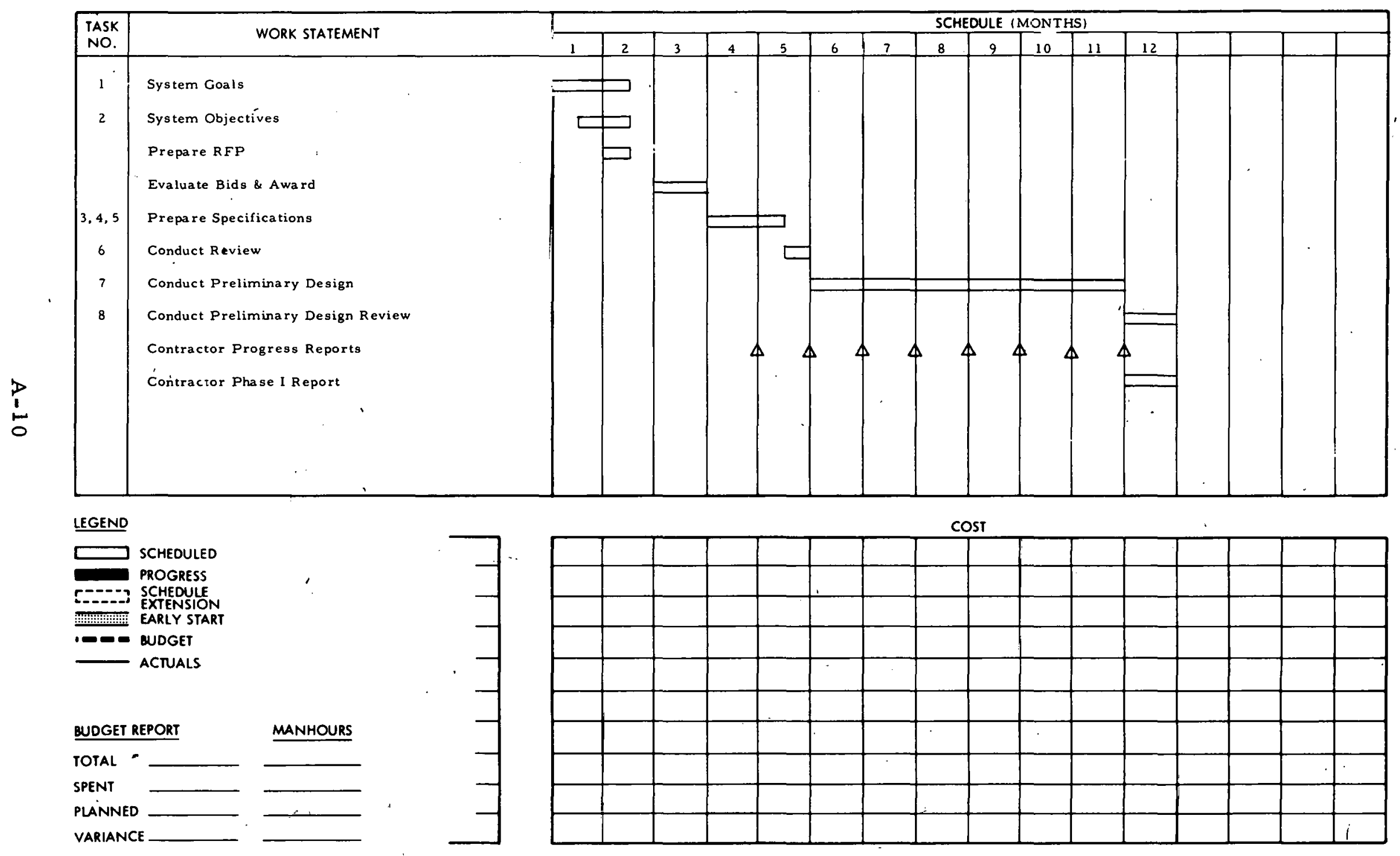

Figure A-3. Phase I Schedule 


\section{Appendix B \\ EXAMPLES OF PROCESS HEAT APPLICATIONS \\ OF THE CPC DESIGN CONCEPT}

\section{DEVELOPMENT OF INDUSTRIAL APPLICATION.}

Thus far, it has not been possible to identify a fully commercial use of the CPC design concept in an industrial application. However, at least one entrepreneurial firm is developing this concept into a product, as described in the following example.

\section{Description:}

A small industrial metal fabricating firm is about to introduce solar heating equipment for use-with wood waste, chemical or other industrial process industries. Earliest use may be in the forest products industry sectors; SIC 24 and 26.

Principal Function:

Production of low pressure steam or hot water using solar energy to supplement wood waste fuel-fired boiler heating in general heating applications, and also to stretch out diminishing supplies of natural gas in the face of threatened cutbacks in allocations of this fuel.

\section{Solar System Costs:}

Collector cost, estirriated at $\$ 3,600$ for a $3 \times 8 \mathrm{ft}$ panel. Vendor estimates that the payback period is from 10 to 12 years. Solar generated steam or hot water, in general, may represent only a small percentage of the total heat value. 
Solar Collector:

Flat panels producing steam or water.

Size and Location: Depends on specific application (prefab panel module, $3 \times \mathrm{ft}$.)

Performance: $60 \%$ efficiency at working temperature of $300^{\circ} \mathrm{F}$, steam or water, fired by solar radiation at a level of $300 \mathrm{Btu} / \mathrm{h} \dot{\mathrm{r}}$ per $\mathrm{ft} .{ }^{2}$

Other Components:

Conventional boilers, burners, wood conveyance and fuel preparation equipment. systems, including ash removal and the balance of boiler plant equipment.

\section{Expected Life of Solar System:}

Design goal: minimum 20 years. The useful life of conventional boiler equipment used in these applications may be as low as 12 years. Potential users generally amortize the heating plant in 6 to 8 years.

\section{Solar Collector Design - Proprietary:}

Basic CPC trough is approximately 10 inches deep. The firm's design goal is to produce the collector for sale at a retail price of $\$ 15 / \mathrm{ft}^{2}$ in order to be competitive with non-concentrating flat-plate collectors selling in the range of from $\$ 7 / \mathrm{ft}^{2}$ to $\$ 13 / \mathrm{ft}^{2}$.

Solar System Vendor:

Firm prefers to remain unidentified at this time. 


\section{A SUGGESTED APPLICATION IN THE BAKING INDUSTRY}

\section{Description:}

Establishments in this industry sector (SIC 205) are primarily engaged in manufacture of bread, cakes, and other bakery products, including both "perishable" and "dry" products, such as cookies, crackers, etc. Typically 1.5 to 2 percent* of the wholesale value of production in this sector is attributed to fuel costs for baking. Baked goods are produced in virtually every metropolitan urban center in the United States.

\section{Principal Function:}

Supplement process heat in baking ovens to maintain temperatures as high as $420^{\circ} \mathrm{F}^{*}$ to stretch out diminishing supplies of natural gas during periods of greatest insolation. Duty cycle* of ovens may be from a few hours (usually a.m.) to as many as 20 hours per day, five to six days per week.

\section{Solar System Costs:}

Investigation of costs of large size CPC solar collectors, with medium-to-high optical concentration and of future designs of solar thermal baking ovens equipped with conventional gas burners, have been deferred to subsequent phases of the Goals Study.

\footnotetext{
* Source: Private communication from local bakery chain operator.
} 
However, new conventional ovens are reputed to cost in the neighborhood of $\$ 250,000$, installed.

It appears to be much more economical to completely rebuild a used oven, by a factor of four. Rehabilitation of used ovens with the addition of supplemental solar heating is suggested as a possible design goal for the application of largesize CPC collectors.

Solar Collector - CPC Baking Oven (heated cavity):

Size: Large, cone or trough, according to size of oven. Concentration ratio: "Estimated $X 8$ or greater.

Tracking requirements: Suggested to sustain high temperature. Diurnal tracking may be limited to a few hours before and after.solar noon. ${ }^{* * *}$ Seasonal adjustments are fully warranted.

\section{Other Components:}

Conventional thermostatic controls for gas burners. Fractional horsepower motor-driven automatic controls or other means of solar tracking. No storage or heat transfer fluid needed, if a direct solar heat exchange medium is employed in heating the oven cavity. Selective surface absorbing material and the use of heat resistant oven glass, single pane, or double pane evacuated panel, is likely to be required in achieving the desired oven performance characteristics. Uniform heat distribution is required. Moveable insulation panels may also be required to seal off the oven thermally during periods when the solar system sees a cool sky.

\footnotetext{
***instantaneous performance of design concept has not yet been investigated. Further study is needed to evaluate the overall feasibility of this and of all other applications requiring temperatures in the range of $400^{\circ} \mathrm{F}$ to $600^{\circ} \mathrm{F}$.
} 
Expected Life of Solar System:

Comparable with lifetime of conventional ovens - average of 20 years.

Solar Collector Design:

Basic ANL design concept of compound parabolic concentrator (CPC) with blackbody cavity thermal absorber/oven.

\section{Solar System Vendor:}

The suggested innovation is at the earliest conceptual stage. Commercialization is estimated to require a period. of product design and development of at least 2 years. Specialists in contract and heat engineering work, possibly job shop operations, would be most likely employed in rebuilding and installing bakery ovens equipped with supplemental solar heating. 
GENERAL COMMENTS ON INDUSTRIAL PROCESS HEAT APPLICATIONS OF CPC COLLECTORS

The advantages and disadvantages given below indicate pos sible points to to explored in subsequent phases of the goals study.

Advantages of CPC Design Concept

Diffuse radiation adds slightly

to CPC performance

High efficiency, above 50 percent, at typical working temperatures

Wide angle of solar acceptance eases tracking requirements
Disadvantages

High initial cost

Possible need for seasonal adjustment 


\section{Appendix C \\ EXAMPLES OF COMPETITIVE COMMERCIAL SOLAR SPACE HEATING APPLICATION}

In the time available in the initial phase of the goals study, research provided data on the following examples of commercial practice in space heating:

- CPC collector used in a space heating application in the Rocky Mountain area

- Competitive solar collector in use in the same geographic area

- An experimental development by a large industrial firm, at a similar latitude

All three are leading-edge developments. It is recommended that these types of systems be followed closely in future studies to determine ongoing trends in industrial space heating. No solar cooling applications in industry were uncovered in the course of this study. However, a large multi-client sponsored study costing from $\$ 1-1 / 2$ to 2 million is currently being conducted by $A$. $D$. Little, Inc. The results of this study should reveal more information about the future outlook for industrial space heating and may launch a new solar industry in HVAC which will serve all the markets: industrial, residential, and comm ercial. That study estimated that the market for solar heating and cooling equipment above could amount to $\$ 1$ billion over the next ten years. 
COMMERCIAL BUILDING SPACE HEATING APPLICATION (as submitted for bid)

Building Commercial/Public transportation

Description Airport terminal building valued at $\$ 350,000$

Floor space: $12,800 \mathrm{ft}^{2}$

Principal

Function

Space heating - active solar heating, 75 percent of total heat requirements. Electric resistance heating for the remainder to provide comfort heat at $65^{\circ} \pm 3^{\circ} \mathrm{F}$ to shelter passengers and airline personnel.

Solar

System

Cost

Estimated total system cost: $\$ 27,000$ comprising CPC solar collectors with 'Alzak' aluminum reflectors and Revere Copper energy receiver units at a cost of $\$ 16,000$ and auxiliary equipment at $\$ 11,000$.

Solar $\quad$ CPC recirculating water system

Collector

Size: $2,000 \mathrm{ft}^{2}$ (4troughs, approximately $6 \times 8 \mathrm{ft}$ )

Concentration factor: $x 2.7$ (2.7 suns preferred for Rocky Mountain area)

Tilt: Facing South, aperture $50^{\circ}$ from horizontal

Location: Along Southside of building mounted on an existing concrete apron

Other

Components

Two overnight heat storage galvanized tanks, water capacity 4,000 gallons raised to a maximum temperature of $160^{\circ} \mathrm{F}$. Heat exchanger, automatic controls, pumps, antifreeze in recirculating water-collector loop.

Expected

Life of lie

Estimated at 25 to 30 years by the designer.

Solar System

Solar

Dr. Frank Kreith

Collector

Design

Solar

System

Vendor

CPĆ trough design implemented by:

Dr. Frank Kreith

Environmental Consulting and

Copeland, Finholm,

Services, Inc. Hagman and Yaw

340 Arapahoe Street Architects

Boulder, Color ado 210 S. Galena Street

Aspen, Colorado 81611 
COMMERCIAL BUILDING SPACE HEATING APPLICATION*

Building

Commercial/Industrial

Description

Corporate headquarters, valued at approximately $\$ 1$ million Total floor space: $41,000 \mathrm{ft}^{2}$ of which $7,180 \mathrm{ft}^{2}$ is heated. office and showroom

Principal Space heating - solar 77 percent of annual space heating budget

Function for office and showroom, supplemented by conventional gas fired forced air heating, 23 percent. (Fabrication and warehouse areas employ gas space heaters.)

Solar

Estimated cost of installed system: $\$ 60,000$

System

Costs

Solar collectors, heat storage, controls and air handling equipment: half the cost.

Maintenance costs expected to be nil (by Glass Co. President)

Solar

Collector

Flat Plate Hot Air Unit

Size: $1,600 \mathrm{ft}^{2}$ (16 prefab modules, $20 \times 5 \mathrm{ft}$ double glass panes per module).

Tilt: To the South, $50^{\circ}$ from the horizontal for Denver's $40^{\circ}$ latitude.

Location: Mounted on flat roof of one-story plant over heat ducts.

Other

Components

Heat storage bin, $8 \times 8 \times 16 \mathrm{ft}$, containing 50 tons of pebbles

Automatic controls

Air handling equipment

Expected Comparable with life of building -20 to 30 years

Life of

Solar System

Solar

Collector

Design

Solar

System

Vendor

Dr. George O. G. Lof supplied early R\&D work in hot air solar collectors.

Solaron Corporation

Stapleton Field Industrial Park

4850 Olive Street

Denver, Colorado 80022
John C. Bayless, President

George O. G. Lof, V.P. and Founder

Phone: (303) 289-2288

* Source: U.S. Dept. of Commerce - Commerce Today, April, 1975. 
EXPER IMENTAL INDUSTRIAL SPACE HEA : ING (If successful, similar systems may be added to other buildings.)

Building

Description

Principal

Eunction

Solar

System

Costs

Solar

Collector

Other

Components

Expected Life

of Solar

System

Solar

Collector

Design

Solar

System

Vendor
Light industrial/computer equipment systems manufacturing plant, assembly and test Total floor space: $165,000 \mathrm{ft}^{2}$

Space heating to augment conventional energy conservation measures adopted in the past two years. Air is blown through large coils heated by water from the solar collectors introduced into the boiler loop system. Natural gas and standby diesel fuels will supply the energy for heating on cloudy days.

Estimated cost at completion of retrofit, scheduled for October 1975, $\$ 15,000$. Projected savings in fuel costs: \$12,000 annually. As a public service, installation process has been videotaped so that others may duplicate it.

The company's material costs were under $\$ 2 / \mathrm{ft}^{2}$ for panels that could be made with no tooling investment.

Flat Plate, closed water circulation

Size: $8,480 \mathrm{ft}^{2}$ (265 panels, $8 \times 4 \cdot \mathrm{ft}$, single glass cover).

Tilt: 380 from the horizontal, compromise for summer and winter for Sunnyvale's 380 latitude.

Location: Mounted on flat roof of one story plant.

Overnight heat storage, water capacity 14,000 gallons, maintained between $130^{\circ}$ to $140^{\circ} \mathrm{F}$, water pumps, air blowers, piping, and controls, conventional gas and diesel fuel-fired boilers.

With carefully controlled $\mathrm{Ph}$, at least 20 years, free of corrosion

Single, 1/8"'; double strength, window glass cover. Corrugated aluminum painted flat black.

Fastened with 300 pop rivets per panel to back aluminum sheet. Serpentine aluminum tubing, $65 \mathrm{ft}, 1 / 2 " \mathrm{O} . \mathrm{D}$.

Celotex, 1/2" thick insulation.

Plywood box.

Water circulated through tubing is raised as much as $18^{\circ} \mathrm{F}$ on each pass. A 2-1/2 gallons per minute flow rate is considered optimal for heat transfer.

None - User does not plan to manufacture solar heaters on a commercial basis.

Automatic Measurement Division

Mr. Martin McFee

of Hewlett-Packard Co.

974 East Arques Avenue

Sunnyvale, California

Plant Supervisor

(408) $735-1550$ 
Appendix D

\section{GLOSSARY OF IMPOR TANT TECHNICAL TERMS}

Emittance

Absorbtance

Reflectance

Transmittance

Global Radiation

Direct Radiation

Diffuse Radiation

Collector Efficiency

Optical Efficiency
Measure of the capability of a body to radiate energy.

The fraction of radiant energy incident on a body that is absorbed by that body.

The Iraction of radiant energy falling on a body that is reflected.

The fraction of radiant energy passing through a body.

Radiation coming from all directions. The sum of direct and diffuse radiation.

Almost parallel (23 minutes of divergence) radiation coming directly from the sun.

Radiation coming indirectly from the sun by virtue of multiple reflection, scattering, or re-radiation by the earth's atmosphere.

The ratio of heat output of the collector to the total amount of radiant energy falling on the collector surface.

The theoretical maximum percentage of collected global radiation that is conveyed to an absorbing surface where the eneryy is converted to another energy form.

That collector component which receives radiant energy and converts it to extract-. able the rmal or electric energy. 
Acceptance Angle

Diurnal Tracking

Insolation

Flat Plate Collector

Concentrating Collector

Compound Parabolic Concentrator (CPC)

Selective Surface
The maximum angle at which radiation is collected, and is indirectly related to the $f$ number describing the optical properties of an imaging collector.

Following the-sun along its daily path.

Incident solar flux in units, such as Btu/hr-ft ${ }^{2}$ or in Langley's.

The class of non-concentrating solar devices, such as flat panels, that collect both the direct and diffuse portions of global radiation.

The class of solar collectors that concentrate the direct portion of global radiation incident upon the aperture of the collector.

The class of non-imaging reflective surfaces used as a part of a solar collector to concentrate radiant energy into a receiver with a maximal concentration, i. e. collection of energy in the receiver.

A surface of a body which provides a high degree of absorptance of radiant energy with a low degree of emittance over a spectral range. 


\section{BIBLIOGRAPHY}

1. AAI Corporation. Solar Heating Proof-of-Concept Experiment for a Public School Building. Report for the period 15 January 1974 to 15 May 1974. Washington D. C. : GPO, June 1974. (ER-7934).

2. The Aerospace Corporation. Mission Analysis of Photovoltaic Solar Energy Systems; annual progress report covering the period July 1, 1974 to December 31, 1974. January 31, 1975. (NSF/RANN/SE/GI-44099/PR/74/4).

3. "Year End Estimates." AGA News, (December 31, 1974).

4. American Institute of Architects' Energy Steering Committee. A Nation of Energy Efficient Buildings by 1990. Washington D.C.: American Institute of Architects, 1975.

5. American Institute of Architects' Research Corporation.

"Report to National Bureau of Standards and HUD on solar building designs." (In preparation).

6. American Society of Heating, Refrigerating and Air-Conditioning Engineers, Inc. ASHRAE Guide and Data Book, Equipment, 1972. New York, New York: ASHRAE, 1972.

7. American Society of Heating, Refrigerating and Air-Conditioning Engineers, Inc. ASHRAE Handbook and Product Directory, 1974 Applications. New York, New York: ASHRAE, 1974.

8. American Society of Heating, Refrigerating, and Air Conditioning Engineers, Inc. Low Temperature Engineering Application of Solar Energy. Edited by Richard C. Jordan. New York, New York: American Society of Heating, Refrigerating, and Air Conditioning Engineers, Inc., 1967.

9. Argonne National Laboratory. Report on X10 Compound Parabolic Collector. Argonne, Illinois: Argonne National Laboratory, May 1975.

10. Argonne National Laboratory, and the University of Chicago. Solar Energy Concentration; annual progress report covering the period July 1, 1974 to December 31, 1974.. February 1975. (NSF/RANN/SE/AER-75-01065/PR/75/4). 
11. Arizona. State Fuel and Energy Office. Putting the Sun to Work: A History and Directory of Currently Available Applications. By Ken Bacher. Springfield, Va.: NTIS 1974.

12. Arizona State University, and Spectrolab Division of Textron, Inc. Terrestrial Photovoltaic Power Systems with Sunlight Concentration; annual progress report covering the period January 15, 1974 to December 31, 1974. January 31, 1975. (NSF/RANN/SE/GI- 41894/PR/74/4).

13. Arthur D. Little, Inc. "Solar Climate. Control Project Report." (Proprietary, multi-client sponsored study), 1975.

14. Athey, Roderick E. Evaluation of the Flat Plate Solar Collector System for Electric Power Generation. Kansas City, Missouri: Black \& Veatch.

15. Auburn University Engineering Systems Design. Summer Faculty Fellows. Terrestrial Application of Solar Technology and Research (TERRASTAR); final report. Auburn, Alabama: School of Engineering, Auburn University, September 1973. ( $N^{\top} A S A$ CR-129012).

16. Bannerot, Richard B., and Howell, John R. Measurement of the Effects of Surface Geometry Modification on the Radiative Performance of Solar Energy Collectors; technical report. Houston, Texas: Univcrsity of Houston, February 21, 1975. (NSF/RANN/SE/GI-41003/TR/75/1).

17. Bennett, I. "Monthly Maps of Daily Isolation in the U.S." Solar Energy, IX, no. 3, (1965).

18. Boer, K.; Freedman, N.; Hadley, H.; Nelson, W., et al. Flat Plate Collectors with CDS Solar Cells and First Indications of Feasibility for Their Large Scale Use. Newark, Delaware: University of Delaware, June 1, 1973.

19. Bridgers, F.H., and Paxton, D. D. "Solar Heat for a Building." Mechanical Engineering, (June 1957).

20. Broncki, L. Y. "The Ormat Rankine Power Unit." Proceedings 7 th Intersociety Energy Conversion Engineering Conference, San Diego, California, September 25-29, 1972. 
21. Private communication. Bryant Air Conditioning Co., Indiana polis, Indiana, May 30, 1975.

22. California Institute of Technology. Jet Propulsion Laboratory. Assessment of the Technology Required to Develop Photovoltaic Power Systems for Large-Scale National Energy Applications, October 15, 1974. (NSF-RA-N-74-072) (JPL Special Publication 43-11).

23. Photovoltaic Conversion of Solar Energy for Terrestrial Applications, October 15, 1974 (NSF-RA-N-74-073) (JPL Special Publications 43-12).

24. - Photovoltaic Solar Array Technology Required for Three Wide Scale Generating Systems for Terrestrial Applications Rooftop, Solar Farm and Satellite. By P.A. Berman. Springfield, Va.: NTIS, October 1972. (NASA-CR-128381) (JPL-TR-32-1573).

25. - Workshop Proceedings. Photovoltaic Conversion of Solar Energy for Terrestrial Applications: Vol. I. Working Group and Panel Reports: Vol. II. Invited Papers. Washington D.C.: National Science Foundation, RANN, (1973). (NSF-RA-N-74-013).

26. California Polytechnic State University. Research on the Application of Solar Energy to the Food Drying Industry; thi rd quarter progress report covering the period July 1, 1974 to September 30, 1974. By Thomas Lukes. Washington D. C.: Rann Document Center, October 1974. (NSF/RANN/ $\mathrm{SE} / \mathrm{GI} 42944 / \mathrm{PR} / 74 / 3)$.

27. Calvert, Floyd O., and Harden, Darrel G. "Solar Assisted Heat Pumps for Energy Conservation in Environmental Control." DMG-DRS Journal, IX, no. 3, (July-September 1975).

28. Cassel, T.A. V. Integrated Solar Energy Assisted Vapor Compression Heat Pump Systems. Philadelphia, Penna.: National Center for Energy Management and Power, University of Pennsylvania, May 1974. (NCEMP-24). 
29. et al. "Solar Heat Pump Comfort Heating System." Proceedings 10th Intersociety Energy Conversion Engineering Conference, Newark, Delaware, August 1975.

30. , and Lorsch, Harold G. The Design and Performance of a Prototypc 4 by 4 Foot Inclined Solar Collector. Philadelphia, Penna.: National Center for Energy Management and Power, University of Pennsylvania, May 1974. (NCEMP-23).

31. Chao, B. T., and Rabl, A. Method of Improving Thermal Efficiency of Cylindrical Concentrators for Solar Energy. Argonne, Illinois: Argonne National Laborátory, March $24,1975$.

32. Colorado State University, and University of Wisconsin. Design and Construction of a Residential Solar Heating and Cooling System; semi-annual progress report covering the period January 1, 1974 to June 30, 1974. Springfield, Va.: NTIS, July 1974. (NSF/RANN/SE/GI-40457/PR/74/2).

33. Colorado State University, and Westinghouse Electric Corporation. Solar Thermal Electric Power Systems; final report. Vol. 1. Executive Summary. Vol. 2. System Studies and Economic Evaluations. Vol. 3. Appendices. Fort Collins, Colorado: Colorado State University, November 1974. (NSF/RANN/SE/GI-3781 5/FR/ 74/3).

31. Corning Glass Works. Tubular Evacuated Solar Collectors.

35. Cox, John-Robertson. Architectural Planning and Design Analysis of Energy Conservation in Housing Through Thermal Energy Storage and Solar Heating. Philadelphia, Penna.: University of Pennsylvania, September 1972. (NSF/RANN/ SE/GI 27976/TR72/2).

36. Cunnington, G. R., and Streed, E. R. "Experimental Performance of a Honeycomb Covered Flat Plate Collector." (Reported at the annual meeting of the International Solar Energy Society, Cleveland, Ohio, NASA Lewis Research Center, October 3-4, 1973).

37. 'Daniels, F. Direct Use of the Sun's Energy. New Haven, Conn.: Yale University Press, 1964. 
38. and Duffie, John A., ed. Solar Energy Research. Ann Arbor, Michigan: Xerox University Microfilms, 1975.

39. - "The Solar Era: Power Production with Small Solar Engines." Mechanical Engineering, (September 1972).

40. Dubin, Mindell-Bloome Associates; AIA Research Corporation; and Heery and Heery. Energy Conservation Design. Guidelines for Office Buildings. Washington D.C.: U.S. General Services Administration, January 1974.

41. Eibling, J.A. "A Survey of Solar Collectors." Proceedings of the Solar Heating and Cooling for Buildings Workshop, Washington D. C., March 21-23, 1973.

42. Eldridge, Frank R. Mitre Photovoltaic Energy System Study. McLean, Virginia: The Mitre Corporation, October 1973. (M73-238).

43. Energy and the Built Environment, bi-monthly report no. I (a service of American Institute of Architects', Energy Opportunities Notebook).

44. Environmental Consulting Services, Inc. Performance Study of the Compound Parabolic Concentrator Solar Collector. September 23, 1974 .

45. Farber, E., and Prescott, G. "Closed Cycle, Solar Hot-Air Engines I and II." Solar Energy, IX, no. 4.

46. Frieling, D. Personal communication. Battelle Laboratories, Columbus, Ohio, June 3, 1975.

47. Gajewski, R. Personal communication. American Science and Engineering Co., Cambridge, Massachusetts, June 3, 1975.

48. General Electric Co. Solar Heating and Cooling of Buildings. Phase 0. Fea sibility and Planning Study; Final Report. Vol. I. Executive Summary; Vol. II. Technical Report; Vol. III. Books 1, 2, 3, Appendices. Springfield, Va.: NTIS, May 1974.

49. Giugler, R.; Rabl, A.; Reed, K., et al. Compound Parabolic. Concentrator. Argonne, Illinois: Argonne National Laboratory, May 1975. 
50. Glaser, Dr. Peter E. An Overview of Solar Energy Applications. Testimony before the Joint Committee on Atomic Energy, United States Senate. Cambridge, Mass.: Arthur D. Little, Inc. , May 7, 1974.

51. Graf, J. Personal communication. General Electric Co., Valley Forge, Pa., June 11, 12, 1975.

52. Hale, H. Personal communication. Carrier Air Conditioning Co., Syracuse, New York, May 23, 1975.

53. Hammond, James. "Life Cycle Costing for Government Procurement." Industrialization Forum, V, no. 1-2, (1974).

54. Hay, H. R. Energy, Technology, and Solarchitecture. New York, New York: The American Society of Mechanical Engineers. (72-WA/Sol-11).

55. _ _The Solar Era: Implications and Adaptations." Mechanical Engineering, (October 1972).

56. Helms, T. Personal communication. Arkla Industries, Inc., Little Rock, Arkansas, June 11, 1975.

57. Hittman Associates, Inc. Assessment of the Rankine Cycle for Potential Application to Solar-Powered Cooling of Buildings. By H. M. Curran, M. Lokmanhekim, T. Alereza and others. Springfield, Va.: NTIS, August 1974.

58. Housing and Urban Development (HUD) and California Folytechnic State University. "Atascadero Solar House Evaluation." (Report in progress).

59. Howell, John R., and Bannerot, Richard B. The Evaluation of Surface Geometry Modification to Improve the Directional Selectivity of Solar Energy Collectors; annual progress report covering the period January 1, 1974 to December 31, 1974. Houston, Texas: University of Houston, January 31, 1975. (NSF/RANN/SE/GI-41003/PR/74/4).

60. - The Evaluation of Surface Geometry Modification to Improve the Performance of Solar Energy Collectors; technical report. Houston, Texas: University of Houston, December 15, 1974. (NSF/RANN/SE/GI-41003/TR/74/1). 
61. Hsu, S. T., and Leo, B.S. "A Single Reaction Turbine as a Solar Engine." Solar Energy, II, III, IV, (1958).

62. International Solar Energy Society. Annual Meeting of the U.S. Section. (Held at NASA Lewis Research Center, Cleveland, Ohio, October 3-4, 1973).

63. - (Held at Fort Collins, Colorado, August $21-2 \overline{3,1974) .}$

64. Jordan, R. C. , and Ibile, G. "Mechanical Energy Conversion." Proceedings of World Symposium on Applied Solar Energy, November 1955, 1956.

65. Killian, Harrison J.; Dugger, Gordon L. ; and Grey, Jerry, ed. Solar Energy for Earth. An AIAA Assessment. New York, New York: American Institute of Aeronautics and Astronauts, April 21, 1975.

66. Kramer, W. Personal communication. Talley Industries, Mesa, Arizona, May 30, 1975.

67. Kreith, F. Personal communication. Environmental Consulting Services, Boulder, Colorado, June 18, 1975.

68. Lorsch, H. G. "Performance of Flat Plate Solar Collectors." Proceedings of the Solar Heating and Cooling for Buildings Workshop, Washington D. C., March 21-23, 1973.

69. - Solar Heating Systems Analysis. Philadelphia, Penna.: University of Pennsylvania, November, 1972. (NSF/RANN/ SE/GI 27976/TR72/19).

70. , and Niyogi, B. Influence of Azimuthal Orientation on Collectible Energy in Vertical Solar Collector Building Walls. Philadelphia, Penna.: University of Pennsylvania, August 1971. (NSF/RANN/SE/GI 27976/TR72/18).

71. McNeely, L. Personal communication. Bryant Air Conditioning Co., Indiana polis, Indiana, November 2, 1973.

72. MacFadyen, David. "Technology Transfer and Improved Housing Production." Industrialization Forum, III, no. 5, (June $1972)$. 
73. Martin Marietta Corporation. Solar Power System and Component Research Program; final report. January 1975.

74. Maryland, University of. An Assessment of Solar Energy As a National Energy Resource. By Paul Donovan, William Woodward, William P. Cherry, Frederick H. Morse, and Lloyd O. Herwig. Springfield, Va.: NTIS, December 1972. (NSF/RA/N-73-001).

75. - Proceedings of the Solar Heating and Cooling for Buildings Workshop, Washington D. C., March 21-23, 1973. Part I, Technical Sessions, March 21 and 22. Edited by Redfield Allen. July, 1973. (NSF/RANN/SE/ GI-32488/73).

76. - Proceedings of the Solar Thermal Conversion Workshop, Arlington, Virginia, January 11-12, 1973. November 1974. (NSF-RA-N-74-125).

77. "Solar Powered Heat Pump." Mechanical Engineering, April 1975.

78. Medendorp. Personal communication. RAM Products, Sturgis, Michigan, June 10, 1975.

79. Meijer, R.J. "The Philips Stirling Engine." De Ingenieur: Werktuig-en Scheepsbouw.

80. Merrick, R. Personal communication. Arkla Industries, Inc., Little Rock, Arkansas, May 30, 1975.

81. Minnesota, University of, and Honeywell. Research Applied to Solar-Thermal Power Systems; progress report no. 2. Semi-annual progress report covering the period January 1 to June 30, 1973. Minneapolis, Minnesota: University of Minnesota and Honeywell, July 31, 1973. (NSF/RANN/ $\mathrm{SE} / \mathrm{GI}-34871 / \mathrm{PR} / 73 / 2$ ).

82. ; report no. 4. Semi-annual progress report covering the period January 1 to June 30, 1974. Minneapolis, Minnesota: University of Minnesota and Honeywell, July 31, 1974. (NSF/RANN/SE/GI-34871/PR/74/2). 
83. ; report no. 5. Semi-annual progress report covering the period July 1 to December 31, 1974. Minnea polis and Honeywell, January 31, 1975. (NSF/ RANN/SE/GI-34871/PR/ 74/4).

84. The Mitre Corporation. Systems Analysis of Solar Energy Programs, Springfield, Va.: NTIS, December 1973. (NSF/RA/N-73-111A).

85. Monthly Energy Review, (February 1975).

86. National Aeronautics and Space Administration. George C. Marshall Space Flight Center. The Development of a Solar-Powered Residential Heating and Cooling System. Washington D.C.: National Aeronautics and Space Administration, May 10, 1974.

87. National Center for Space Research. Terrestrial Applications of the Photovoltaic Solar Generators. Translated by Scientific Translation Service (Scitran). Springfield, Va.: NTIS, September 1974. (NSAS TT F-15906).

88. National Oceanic and Atmospheric Administration. Report and Recommendations of the Solar Energy Data Workshop, November 29-30, 1973. By Charles Turner. Springfield, Va.: NTIS, September 1974. (NSF-RA-N-74-062).

89. Letter from Olin Brass - Roll Bond Products, East Alton, Illinois, February 1975.

90. Ostadhosseini, A. "Solar Utilization in Residential Heating Systems." (Ph. D. dissertation, University of Pennsylvania, 1972).

91. Pennsylvania, University of. National Center for Energy Management and Power. Conservation and Better Utilization of Electric Power by Means of Thermal Energy Storage and Solar Heating; final summary report. Philadelphia, Penn.: University of Pennsylvania, July 31, 1973.

92. - Interim Standard for Solar Collectors; Semi-annual progress report covering the period January 1 through June 30, 1974. By Noam Lior. Springfield, Va.: NTIS, July 1974. (NSF/RANN/SE/GI 297290/PR74/ 2). 
93. - Test Facility for Experimental Solar Collectors. By A.P. Saunders. Springfield, Va.: NTIS, October 1972. (NSF/RANN/SE/GI 27976/TR72/12).

94. - Towne School of Civil and Mechanical Engineering. Conservation and Better Utilization of Electric Power by Means of Thermal Energy Storage and Solar Heating. Springfield, Va.: NTIS, October 1, 1971. (UPTES-71-1).

95. Pickering, E. "Residential Solar Energy Hot Water Storage." (Report, under the auspices of Stanford Research Institute, in preparation for mid-1975).

96.

"A Practical Solar Energy Heating.and Cooling System." NASA Tech Brief, (May 1973). (B73 10156).

97. Rabl, Ari. Comparison of Solar Concentrators. Argonne, Illinois: Argonne National Laboratory, April 1975. (SOL 75-02).

98. - Optical and Thermal Properties of Compound Parabolic Concentrators. Argonne, Ill.: Argonne National Laboratory, February 1975. (SOL 75-01).

99. ; Sevcik, V.; and Winston, R. Report on Concentrating Flat Plate Compound Parabolic Collectors. Argonne, Ill.: Argonne National Laboratory, December 31, 1974.

100. Ragsdale, Robert G., and Namkoong, David. The NASA Langley Building Solar Project and the Supporting Lewis Solar Technology Program. Cleveland, Ohio: NASA Lewis Research Center. (NASA TM X-71600). .

101. Ralph G. Personal communication. Spectrolab, Sylmar, California, March 6, 1975.

102. Retail Prices and Indexes of Fuels and Utilities, (April 1975).

103. Rom, Frank E., and Thomas, Ronald L. Solar Energy to Meet the Nation's Energy Needs. Cleveland, Ohio: NASA Lewis Research Center. (NASA TM X-68290). 
104. Schmidt, R. "Honeywell Flat Plate Collector Code." Proceedings of the Solar Heating and Cooling for Buildings Workshop, Washington D.C., March 21-23, 1973.

105. Schon, Donald A. "Preface to a Future Policy for Technology in Society." (Unpublished, March 1975).

106. Technology and Change. New York, New York: Dell Publishing Co., Inc., 1967.

107. Shurcliff, W. A. Solar Heated Buildings: A Brief Survey. 8th ed. Cambridge, Mass.: March 27, 1975.

108. Simon, F.F. Status of the NASA Lewis Flat-Plate Collector Tests With a Solar Simulator. Cleveland, Ohio: NASA Lewis Research Center. (NASA TM X-71658).

109. "The Stationary Reflector/Tracking Absorber (SR TA)." Solar Energy News, (August 1974).

110. Solergy, Inc. (Technical sheet on the Solergy collector). May 1975.

111. Stein, Richard G. "Spotlight on the Energy Crisis." AIA Journal, (June 1972).

112. Tabor, H., and Bronicki, L. T. "Small Turbines for Solar Energy Power Package." U.N. Converence on New Sources of Energy, Rome 1961. New York, New York: United Nations, 1964.

113. Tabor, H. "Use of Solar Energy for Production of Mechanical Power and Electricity by Means of Piston Engines and Turbines." Solar Energy, VI, no. 3 (1962).

114. Talbert, W. Personal communication. Tinsley Laboratory, Berkeley, California, May 29, 1975.

115. Thomas, Ronald L. The Utilization of Solar Energy to Help Meet Our Nation's Energy Needs. Cleveland, Ohio: NASA Lewis Research Center. (NASA TM X-68230).

116. TRW Systems Group. Solar Heating and Cooling of Buildings. Phase 0. Vol. I. Executive Summary; Vol. II. Final Report; Vol. III. Appendices, Springfield, Va.: NTIS,

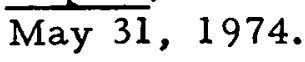


117. and California Polytechnic State University. Solar Assisted Drying of Agricultural Produce: progress report, October 1974.

118. U.S. Congress. House. Committee on Science and Astronautics. Solar Heating and Cooling Demonstration Act. Hearings before the subcommittee on energy, House of Representatives, on H.R. 10952 et al., 93 rd Cong., l st sess., November 13, 14, 15; 1973.

119. U.S. Energy Research and Development Administration. Division of Solar Energy. National Plan for Solar Heating and Cooling (Residential and Commercial Applications): interim report. Washington D.C.: Energy Research and Development Administration, March 1975. (ERDA-23).

120. U.S. National Bureau of Standards. Method of Testing for Rating Solar Collectors Based on Thermal Performance. Springfield, Va.: NTIS, December 1974.

121. U.S. National Science Foundation. Energy, Environment, Productivity. Proceedings of the First Symposium on RANN: Research Applied to National Needs. Washington D. C. , 1973.

122. - National Workshop on Waste Heat, Portland, Oregon, Oregon State University, December 1974. (Papers).

123. Urquhart, D. "Interview." Solar Energy Digest, II, No. 4 (April, 19\%4).

124. Westerman, W. Personal communication. Chamberlain Co., Waterloo, Iowa; June 2, 1975.

125. Westinghouse Electric Corp. Solar Heating and Cooling of Buildings. Phase 0. Executive Summary. Final Report, Volumes I, II, III. Springfield, Va.: NTIS, May 1974.

126. Whole Earth Truck Store; New Alchemy West; Ecology Action/ Palo Alto; and Alternative Sources of Energy Newsletter, ed. Energy Primer. Solar, Water, Wind, and Biofuels.

127. Wilson, W.R., and Wade, J.F. Compilation of Known Information on Martin Marietta Black Surface. Denver, Colorado: Martin Marietta Aerospace, February 1974. 
128. Winegarner, R. Personal communication. Optical Coatings Laboratory, Inc., Santa Rosa, California, May 28, 1975.

129. Winston, R. "Ideal Light Collectors in Cylindrical Geometry." (Report not released by ERDA at this date), April 13, 1975.

130. - Personal communication. Argonne National Laboratory, Argonne, Illinois, June 19, 1975.

131. , and Zwerdling, S. Personal communications. Argonne National Laboratory, Argonne, Illinois, May 1975.

132. - "Principles of Solar Concentrators of a Novel Design." Solar Energy, XVI, (October 1974).

133. , and Hinterberger, H. Principles of Cylindrical Concentrators for Solar Energy. Argonne, Illinois: Argonne National Laboratory, September 1974. (SOL 74-01).

134. Wormser Scientific Corporation. Solar Heating and Cooling Using Reflective Pyramid Optical Condensing System.

135. James, L. W., and Moon, R. L. Ga As Concentrator Solar Cells. Paper presented at the 11 th IEEE Photovoltaic Specialists Conference, Arizona, May 1975. 